\title{
ASPECTOS DA FORMAÇÃO DA IDENTIDADE DO MIGRANTE: PEDAGOGIA DA ESCOLHA, IMAGINÁRIO E SOCIEDADE
}

Tese apresentada à Faculdade de Educação para obtenção do título de Doutor em Educação

Área de Concentração:

Cultura, Organização e Educação

Orientadora: Professora Doutora Katia Rubio 
AUTORIZO A REPRODUÇÃO E DIVULGAÇÃO TOTAL OU PARCIAL DESTE TRABALHO, POR QUALQUER MEIO CONVENCIONAL OU ELETRÓNICO, PARA FINS DE ESTUDO E PESQUISA, DESDE QUE CITADA A FONTE.

Catalogação na Publicação

Serviço de Biblioteca e Documentação

Faculdade de Educação da Universidade de São Paulo

37.01

G516a
Giraldes, Antônio Roberto

Aspectos da formação da identidade do migrante: pedagogia da escolha, imaginário e sociedade/ Antônio Roberto Giraldes; orientador Katia Rubio. São Paulo: s.n., 2016.

116 p.; anexos

Tese (Doutorado - Programa de Pós-Graduação em Educação. Área de Concentração: Cultura, Organização e Educação) - - Faculdade de Educação da Universidade de São Paulo.

1. Pedagogia 2. Identidade 3. Migrantes 4. Imaginário 5. Pós-Modernidade I. Rubio, Katia, orient. 
Nome: GIRALDES, Antônio Roberto

Título: ASPECTOS DA FORMAÇÃO DA IDENTIDADE DO MIGRANTE: PEDAGOGIA DA ESCOLHA, IMAGINÁRIO E SOCIEDADE.

Tese apresentada à Faculdade de Educação da Universidade de São Paulo para obtenção do Título de Doutor em Educação

Aprovado em:

Banca Examinadora

Prof. Dr. Instituição

Julgamento Assinatura

Prof. Dr. Instituição

Julgamento Assinatura

Prof. Dr. Instituição

Julgamento Assinatura

Prof. Dr. Instituição

Julgamento Assinatura

Prof. Dr. Instituição

Julgamento Assinatura 


\section{Dedicatória}

Meu nome é Antônio.

Quando eu era pequeno, pouco me chamavam por esse nome talvez por conta de meu irmão, que também tinha como primeiro nome Antônio.

Mas o nome permanecia solene nos documentos oficiais, na religiosidade de minha mãe e nas expectativas ingênuas minhas de uma experiência existencial, talvez uma identidade.

Minha avó elegia um Santo para cada neto: um dos meus irmãos tinha como protetor Dom Bosco, uma prima tinha Santa Rita e eu tinha Santo Antônio.

As rezas, as doenças de criança e as intercessões relacionadas a mim eram para ele.

Já adulto, escuto esse nome várias vezes ao dia.

A tradição católica de minha família me identifica pelo nome e eu, ao pesquisá-lo, descobri que ele era alguém bastante envolvido com a linguagem, que buscava a erudição mesmo tornando-se franciscano.

Ele era um excelente orador, tanto que, quando foram fazer o traslado de seu corpo, sua língua continuava ilesa.

Dedico esse trabalho a Santo Antônio.

Por ser ele, neste momento de minha vida, a imagem que perpassa pelos caminhos que percorri até hoje, ora distante nas rezas silenciosas de minha mãe, ora vivente na serenidade do olhar da sua imagem, que me faz imaginar as palavras proferidas por ele durante a vida. 


\section{Agradecimentos}

À Professora Doutora Katia Rubio, por mais uma orientação sensível, pela metodologia das Histórias de Vida.

Ao Professor Doutor Rogério de Almeida, pelo Espírito Trágico e as orientações na Pedagogia da Escolha.

Ao Professor Doutor Mesac Roberto Silveira Júnior, pelas dicas da Epistemologia Promíscua e pelas manchas migratórias na estrada.

À Professora Doutora Soraia Chung Saura, pela História de Vida em seu memorial.

À Professora Doutora Lúcia Isaltina Clemente Leão, pela sensibilidade e participação na banca.

À Professora Doutora Katia Abud, pela Consciência Histórica.

À Professora Doutora Claudia Vianna, pela Modernidade Tardia.

Ao Professor Doutor Ulisses Ferreira de Araújo, pelas ajudas Epistemológicas.

A Samea Ghandour, pelos auxílios no grego, na cultura helênica e clássica; pelas discussões de conteúdos; pelas traduções em espanhol e em inglês; pela revisão do texto; mas principalmente, pelo companheirismo e sensibilidade em todos os momentos de caminho do processo.

A Jorge Okubaro e Tadeu Okubaro pelo Japão em sua eterna migrância ao Brasil.

A Tomislav Deur, pelas referências à Croácia.

A meu pai e meus irmãos, pelo sangue e companhia na caminhada.

Aos Sujeitos entrevistados, pela generosidade.

A todos os meus professores e alunos.

A minha mãe, Yara Maria Vasconcellos Giraldes, por todas as vezes que caminhou comigo pelo centro de São Paulo me mostrando livrarias; pela firmeza combativa diante dos problemas da vida; pela preocupação com a expressividade da palavra; pela seriedade e disciplina no trabalho, por acreditar em mim e admirar meu trabalho. 
GIRALDES, A.R. ASPECTOS DA FORMAÇÃO DA IDENTIDADE DO MIGRANTE: PEDAGOGIA DA ESCOLHA, IMAGINÁRIO E SOCIEDADE. 2016. 117 f. Tese (Doutorado) - Faculdade de Educação. Universidade de São Paulo. São Paulo, 2016

\section{RESUMO}

As teorias sobre a identidade, muito mais que se enveredarem por um enredo de métodos que, através do tempo, negam-se para se renovarem; tornam-se uma teia, mandala de observações, critérios e percepções diversos em si mesmos e entre o objeto em questão, num constructo fugidio, todavia, extremamente fascinante para o pesquisador, que se sente um eterno "buscador" da identidade do Homem, "buscador" de si mesmo. O objetivo deste trabalho é estabelecer uma discussão sobre as formas pelas quais esse caminho de identidades pode ser contemplado, relacionando-o com os migrantes e como eles se utilizam das suas experiências para recriarem seus sentidos no mundo e, consequentemente, suas identidades. Para tanto, partindo de EDGAR MORIN e sua concepção da razão complexa, faz-se um entrelaçamento entre alguns campos do saber: um enfoque sociocultural (CASTELLS, BAUMAN e HALL), a antropologia do imaginário e o trajeto antropológico (BACHELARD, DURAND e MAFFESOLI). Nesse entrelaçamento, articulamos conceitos de estereotipia, arquetipia, alteridade e alienação, vinculando-os à globalização, à modernidade tardia, à pedagogia da escolha e ao amor fati (NIETZCHE). Os sujeitos participantes do processo são migrantes, que, a partir de várias formas comunicativas vinculadas às suas histórias de vida (RUBIO), compõem, cada qual, sua identidade. O que se observou, nestes relatos, foram grandes possibilidades de encontros epistemológicos entre antropologia do imaginário e as teorias sociológicas, como se as pontes entre os conhecimentos, ao surgirem, trouxessem caminhos novos à nossa compreensão sobre identidades: coletiva, individual, social ou imaginária. Além disso, nota-se também a migração como ponte e descoberta de percepções sobre o moto-contínuo identitário por que passa a modernidade tardia no que se refere ao mosaico de culturas iluminado pela globalização, entendida tanto como causa quanto como consequência desses fenômenos sociais: o migrante/andarilho e suas histórias de vida ilustram e contemplam verdades e repertórios importantíssimos para uma realização existencial do homem diante da modernidade tardia.

Palavras-chave - Identidade, Migrantes, Pedagogia da Escolha, Imaginário, História de Vida, Pós-modernidade 
GIRALDES, A.R. ASPECTS OF MIGRANTS IDENTITY TRAINING : PEDAGOGY

OF CHOICE, IMAGINARY AND SOCIETY . 2016. $117 \mathrm{f}$. Thesis ( $\mathrm{PhD}$ ) - Faculty of

Education . University of Sao Paulo. São Paulo, 2016

\begin{abstract}
The theories about identity, much more than tread on a place of methods that, throught the times, refuse to be renewed, become a web, observant mandalas, criteria and perceptions varied themselves and between the object in question, in an fleeting construct, however, extremely fascinating for researcher, who is an eternal seeker of the human identity and seeker from itself. The objective of this work is to establish a discussion about the ways in which this identities path can be contemplated, relating it to the migrants and to how they use their experiences to recreate their direction in the world and, consequently, their identities. Therefore, departing from EDGAR MORIN and his conception of complex reason, an interlacing among some fields of knowledge was made: a focus on culture and society (CASTELLS, BAUMAN and HALL), as well imaginary anthropology and anthropological path (BACHELARD, DURAND and MAFFESOLI). In this interlacing, we articulated stereotyped concepts, arquetipia, otherness and alienation, linking them to globalization, the late modernity, the pedagogy of choice and "love fati" (NIETZCHE). The subjects participants of process are migrants that, departing from various communicative forms linked to them life stories (RUBIO), make up, each one their identity. In these stories, great possibilities of epistemological meetings were observed, such between anthropology of the imaginary and sociological theories, as if the bridges between knowledge, by arising, bringed news paths for our understanding about identities: collective, individual, social or imaginary. In addition, migration is noted as bridge and discovery perception's about identity, path on which late modernity spends itself, referring to the cultures mosaic illuminated for globalization, understood both as cause and consequence of those social phenomena: the migrant / wanderer and his life stories illustrate and contemplate truths and repertoires very important to an human existential accomplishment face of late modernity.
\end{abstract}

Keywords - Identity, Migrants, Pedagogy of Choice, Imaginary, History of Life, Postmodernism 


\section{SUMÁRIO}

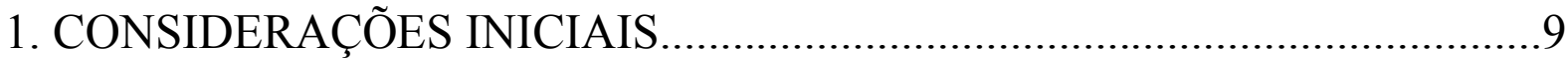

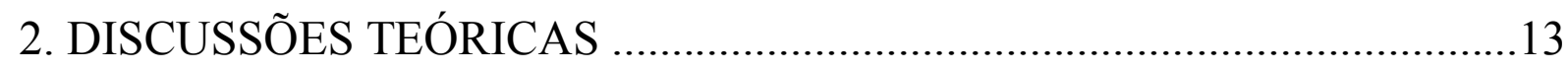

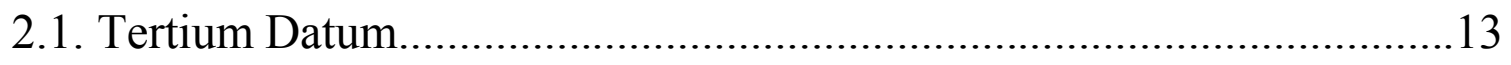

2.1.1. Episteme

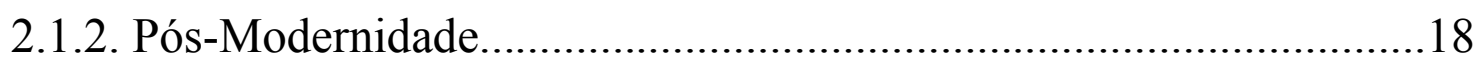

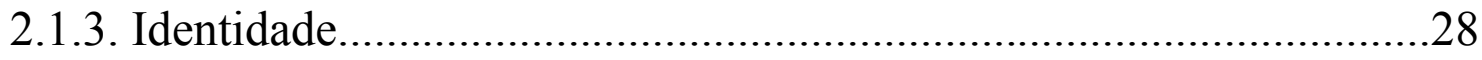

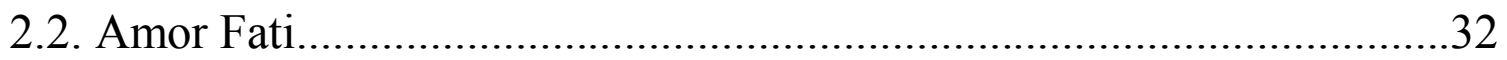

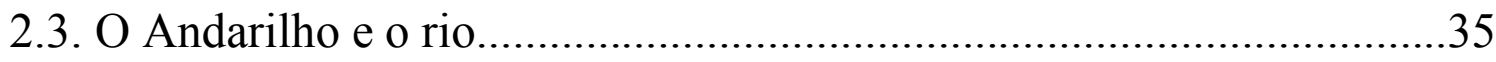

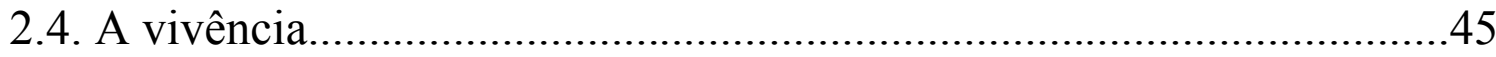

2.5. Lançamento de Âncoras e Vagabundagem Existencial..........................50

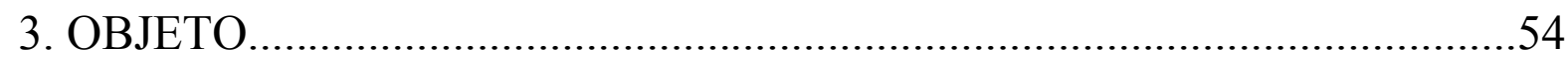

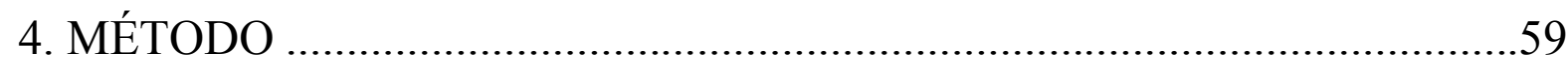

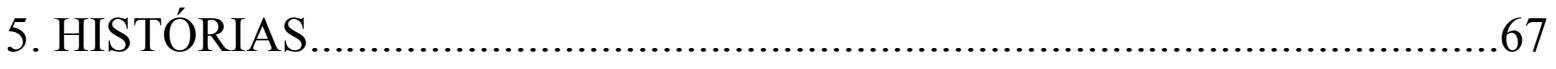

5.1. Resumo da primeira história.............................................................67

5.2. Comentários à primeira história ......................................................68

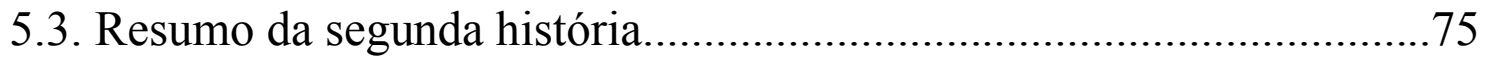

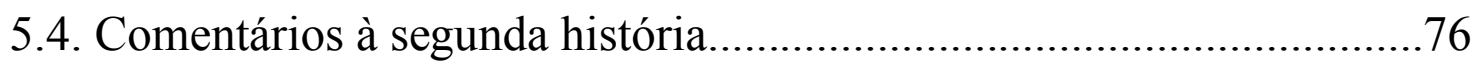

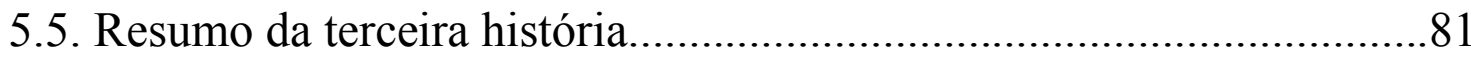

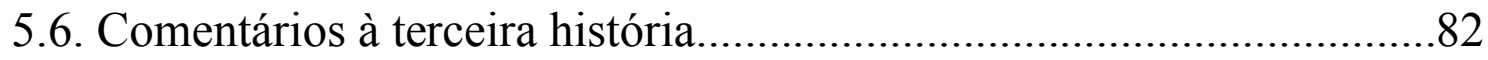




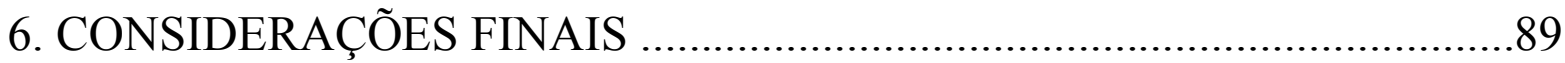

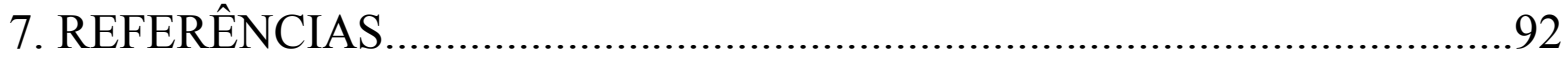

8. ANEXOS

8.1. Anexo A - A Terceira Margem do rio.................................................100

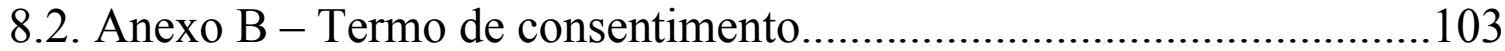

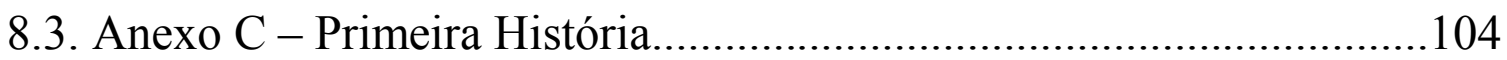

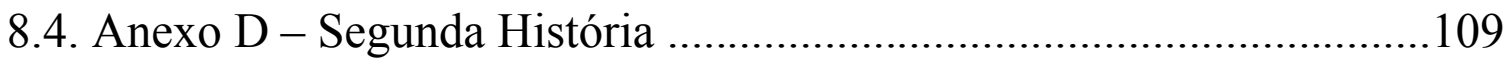

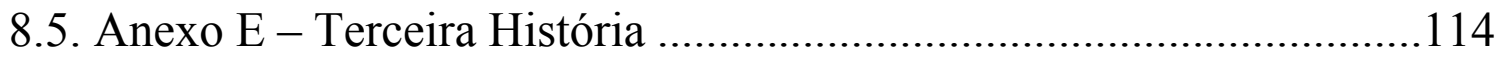

8.6. Anexo F - Parecer da Comissão de Ética .............................................117 


\section{CONSIDERAÇÕES INICIAIS}

Após 18 anos de experiência como professor, consegui, com ajuda e crédito da Professora Doutora KATIA RUBIO, entrar no mestrado e exercitar a pesquisa científica. Se, por um lado, a ausência de experiência acadêmica e o fato de trabalhar em curso pré-vestibular eram fatores que poderiam diminuir a qualidade técnica de meu trabalho, por outro lado, foram eles fonte da pesquisa em si, voltada para a experiência prática e de como ela poderia ajudar em concepções teóricas.

A minha pesquisa de mestrado, propôs-se, em vez de teorias sobre elementos filosóficos para aplicação em sala de aula, fazer o que poucos acadêmicos fazem: conversar com professores e ver o que eles têm a nos ensinar através de suas experiências de vida.

O processo de busca da identidade do professor possibilitou, dessa forma, no fim do caminho, que eu próprio me descobrisse e entregasse aos outros minha experiência para que eles também se descobrissem, ou seja, o trabalho mitohermenêutico, fez com que eu encontrasse nossos heróis, mestres e aprendizes tanto na escola, quanto nas experiências diárias.

Na defesa de minha dissertação, o professor Doutor ROGÉRIO DE ALMEIDA me perguntou qual seria meu próximo passo. Eu estava tão preocupado com o momento que não pensava nos próximos passos. Surpreendi-me. A surpresa e o questionamento sobre o futuro são elementos importantes na criação, pois nos tiram da comodidade e nos permitem farejar caminhos e imaginar o quanto o mundo é grande e, consequentemente, o quanto nós também temos de caminhar.

Naquele momento, disse-lhe que gostaria muito de continuar pesquisando, uma vez que o final de meu mestrado deixou fios soltos (Ariadne, Perséfone, Ulisses). Lembro-me também de lhe dizer que gostaria de descer um pouco do devaneio bachelariano e apoderar-me de algum referencial sociológico mais concreto, talvez construir pontes entre posições do saber que acredito serem interessantes para nossos novos desafios epistemológicos.

Fiz, dessa forma, um exercício postural de tirar meus olhos da lousa e do que ela traria de posicionamentos de mundo e colocar meus olhos do outro lado, nos alunos. Dessa vez me propus a não ver professores e lousa e sim a enxergar alunos.

Vi então vários e vários descendentes de orientais, pensei em todos os anos que passei com eles, no quanto eles tinham me ensinado com suas histórias, aventuras, brincadeiras, brigas, choros, desesperos e reclamações. 
Não sei ao certo o que passei a eles. Na verdade, no íntimo, um professor jamais saberá discernir esse mistério educacional pelo fato de ele próprio ser parte integrante de tal mistério. Sei apenas do encontro que tive com a China, a Coreia, o Japão, a Indonésia, o Vietnã. Convivi com coreanos alfabetizados em castelhano, com netos de japoneses sonhando em retornar ao Japão, com alunos não-descendentes de japoneses desejando morar por lá.

Eis que reencontrei um ex-aluno, descendente de japoneses, que me mostrou o livro de seu pai, no qual era contada a história de um migrante japonês e todas as suas vicissitudes. Tal livro me tocou, pois nele, por incrível que pareça, encontrei meu avô português também migrante.

De posse dessa história, minha orientadora KATIA RUBIO sugere STUART HALL, que, além de ser migrante, representava o contato sociológico necessário para encontrar os alicerces das pontes acadêmicas que procurava.

$\mathrm{Na}$ minha trajetória de estudos, encontrei e reencontrei outros Professores Doutores: CLÁUDIA VIANNA, KATIA ABUD E ROGÉRIO DE ALMEIDA. Com a ajuda deles, lentamente, teci o alicerce, encontros entre filosofias, identidades e histórias. A escola permeava, auxiliando os referenciais sociais, mas a educação em si se mostrava muito além da escola.

No Colégio onde trabalho, costumamos escrever Cartas de Referência para Universidades no exterior a fim de auxiliar os alunos que desejam "migrar" e estudar lá fora. Os alunos, então, nos mandam uma espécie de autobiografia para servir de base à nossa Carta. Recebi, então, um relato muito interessante de uma aluna filha de migrantes japoneses e pus-me a trabalhar nele não só para redigir a tal carta como também para encontrar caminhos nos meus devaneios acadêmicos.

Mostrei minhas divagações à Professora Doutora KATIA RUBIO e ela sugeriu a verificação da escola como elemento acolhedor (hospedaria ou estalagem) ou não desse caldeirão cultural, mas também me disse que eu precisava encontrar outro caminho, talvez menos claro, crepuscular, como considerou posteriormente o Professor Doutor MESAC ROBERTO SILVEIRA JÚNIOR. 
Foi então que minha companheira, SAMEA GHANDOUR, outra migrante, sugeriu que eu falasse dos pais e não dos filhos. Aquilo, possivelmente, me tiraria do caminho seguro da escola. Fiz uma entrevista-piloto com um senhor migrante da Croácia e encontrei o ponto de encontro com a experiência do mais velho e de suas histórias e de como ela traz tanto soluções, quanto princípios e posturas de vida esquecidos na sociedade industrial.

Existe uma tendência política nos países em geral de tratar tanto os mais velhos quanto os migrantes como se fossem somente problemas sociais a serem resolvidos, como se a sociedade tivesse para com eles uma dívida apenas de solidariedade e caridade.

Há, no entanto, que se pensar o quanto de informação importante existe neles, toda uma riqueza cultural solucionaria muitas questões que diagnósticos estatísticos e reformas estruturais não conseguem.

A valorização do migrante coloca em cheque muitas políticas que utilizam a soberania nacional como instrumento de opressão e alienação e pode romper preconceitos e despertar o processo de criação para a solução de muitas questões existenciais que passamos.

A valorização do idoso pode demonstrar o quanto é frágil nosso inflexível sistema escolar, por exemplo, que, raramente, chama alguém mais velho para falar de suas experiências cotidianas com o mais novo e que tende a valorizar conhecimentos teóricos como se parecessem absolutos e atemporais: a maior parte da produção de conteúdo que temos sugere que os conceitos SÃO assim e não ESTÃO assim, talvez essa seja uma herança que o padrão tradicional de ciência deixa para a modernidade tardia.

A história e a experiência vistas como processo no ser humano se transparecem pouco nas instituições em geral, que compõem uma tradição na qual não há tradição, ou seja, o mundo é visto como um imenso universo lógico conceitual desvinculado de emoção, vivência e passado: a arte é tratada com viés de distração ou entretenimento, as guerras e conflitos interpessoais são tratados como desentendimentos entre classes e economias ou desajustamentos individuais, as emoções são caricaturas, muitas vezes vistas como fraquezas.

Talvez precisaríamos de um DIÓGENES a procurar algum ser humano. Alguém que chore com um poema, que sofra pela morte de um avô na guerra, que toque no corpo de seu colega e seja tocado pela sensibilidade da vida, que sinta os poemas como pergaminhos, legados no tempo.

Onde há isso tudo?

Numa pequena conversa com uma pessoa mais velha num café. 
Ao que parece, mais uma vez, olhei para meus alunos e procurei escutar os conselhos de meu pai in memoriam. Hoje ele teria 79 anos. 


\section{DISCUSSÕES TEÓRICAS}

\subsection{Tertium Datum}

\subsubsection{Episteme}

Os grandes poetas são metafísicos fracassados: os grandes filósofos são poetas que crêem na realidade de seus poemas. (NUNES, 2007, p.15)

Parece-nos que tanto os filósofos, quanto os poetas precisam uns dos outros. A Tradição Clássica, quando articula as relações entre poesia e filosofia, tende a criar uma hierarquia em que a poesia se subordina à filosofia. Tal movimento encarcera a filosofia, limitando seu mundo aos seus conceitos de verossimilhança.

A História como fonte de referência de nossa compreensão sobre o lugar e os limites da filosofia e da poesia nos possibilita formas diversas de se ver o passado. Esse passado pode ser, algumas vezes integrado ao presente, presente este que, em vez de opor-se totalmente aos elementos constitutivos do passado, soma-se a ele, amplificando nosso repertório de visões e pluralizando nossa compreensão do mundo.

ANTERO DE QUENTAL, no final do século XIX, por exemplo, em seu poema Hino à Razão, procura, em sua poesia, destacar uma nova ordem, a ordem do racionalismo, opondo essa ordem ao modelo religioso (entendido por ele como do passado), para o qual se justificariam as preces, o movimento dos astros e o heroísmo:

Hino à Razão

Razão, irmã do Amor e da Justiça, Mais uma vez escuta a minha prece, É a voz de um coração que te apetece, Duma alma livre, só a ti submissa

Por ti é que a areia movediça De astros e sóis e mundos permanece;

E é por ti que a virtude prevalece;

$\mathrm{E}$ a flor do heroísmo medra e viça.

Por ti, na arena trágica, as nações

Buscam a liberdade, entre clarões;

E os que olham o mundo e cismam, mudos.

Por ti, podem sofrer e não se abatem, Mãe de filhos robustos, que combatem Tendo o teu nome escrito em teus escudos! (QUENTAL, 1972, p.349) 
Trata-se aqui de uma exaltação à Ciência entendida hoje como Moderna. Uma valorização através da poesia, da metafísica e da filosofia. O poeta coloca a ciência no lugar de DEUS (o contexto sócio-histórico do poema nos apresenta o DEUS judaico-cristão): distante do Homem, absoluta, inquestionável, provedora e independente. Os Astros não respeitam mais DEUS, respeitam o pensamento lógico, que prossegue livre até do próprio Homem que o criou:

O sujeito da modernidade, que crê ter um ponto de vista semelhante à perspectiva de Deus, ou seja, externo ao mundo, absoluto e universal, aquele que se separa da natureza para dominá-la, que faz do saber um poder, esse sujeito cartesiano não pode dar conta de si mesmo, está fora do quadro do universo, como o pintor da perspectiva. A suposição de um conhecimento objetivo eliminou a subjetividade do sujeito como algo digno de ser levado em conta pela ciência e pela sociedade. (NAJMANOVICH, 2001, p.79)

O pensamento científico apresentado, por um lado, molda o mundo num rigor matemático e lógico; por outro lado, vê a si mesmo como uma infinita e absoluta produção de saberes, excluindo, de certa forma, o próprio sujeito analisado. Em outras palavras, somam-se à ciência princípios cristãos de sabedoria e de orientação do passado: responder questões básicas da humanidade e, com as respostas, propor um determinado modo de vida.

Cristo morreu uma só vez, faz parte da História, indica um caminho único até o fim perfeito (juízo final). Da mesma forma, a Ciência Moderna indica percursos de vida à sociedade (dieta, exercícios físicos, como se relacionar com a família, como criar os filhos, como tratar de doenças do corpo ou da mente) fazendo do processo lógico de construção de conhecimento um projeto direcionado a um fim absoluto, em que as grandes e universais verdades serão conquistadas e a perfeição chegará a todos. MAFFESOLI lê essa postura, antropologicamente, pela construção de sentido nas línguas latinas:

O sentido projetava-se. Sob esse aspecto, basta observar que, em numerosas línguas latinas, o sentido significa ao mesmo tempo a finalidade e a significação. O que implica que só tem sentido (significação) aquilo que tem um sentido (finalidade). Como indicam estas antigas expressões filosóficas "logos spermaticus", "ratio seminalis". A razão era projetiva. (MAFFESOLI, 2010, p. 59).

MIRCEA ELIADE, por sua vez, demonstra essa afinidade das intenções científicas, políticas e religiosas quando comenta sobre o marxismo: 
Para o militante marxista, é aqui que está o segredo do remédio para o terror da história: da mesma forma que os contemporâneos de uma "era obscura" consolavam-se, diante dos seus sofrimentos cada vez maiores, com o pensamento de que o agravamento do mal acelera a libertação final, os militantes marxistas dos nossos dias interpretam o drama provocado pelas pressões da história como um mal necessário, um sintoma premonitório da aproximação da vitória, que colocará um fim permanente a todos os 'males' históricos. (ELIADE, 1992, p.129).

O marxismo é uma das formas pelas quais a ciência se dispõe tanto como diagnóstico dos males sociais quanto como panaceia salvadora, no entanto, a própria História e suas pressões levantadas pelos marxistas se dispõem a uma reinvenção da postura científica e ideológica. Tal como um exército que se direciona ao desconhecido e, num determinado momento, encontra algo que o impede de prosseguir, a Ciência também encontra seus limites e o projeto de busca de um ponto cada vez mais avançado e mais próximo da verdade esvai-se diante da incerteza:

A primeira observação, que não é tão trivial quanto parece, é que a identificação dos limites, das insuficiências estruturais do paradigma científico moderno é o resultado do grande avanço no conhecimento que ele propiciou. $\mathrm{O}$ aprofundamento do conhecimento permitiu ver as fragilidades dos pilares em que se funde. (SANTOS, 2008, p.41)

Talvez o pilar mais frágil esteja nessa busca do absoluto, de apenas uma verdade. A Teoria do Caos, de certa forma, demonstra uma relação dialética entre ter ou não ter controle sobre a verdade e como um modelo científico tende a forjar uma realidade que possa ser compreendida naquele momento, com os meios dos quais o Homem possui.

A teoria do caos surge nos anos de 1960 e de 1970 das mãos de Lorenz e de Ilya Prigogine. Seu objetivo é explicar a complexidade e as mudanças dos sistemas [...] a realidade nos é apresentada absolutamente indeterminada, por isso nos é impossível o conhecimento exato da mesma. (COLOM, 2003, pp. 91, 92.

Outro limite da Ciência, que podemos articular com o conceito do saber absoluto, é a especialização do cientista. Pelo modelo cartesiano, deve-se dividir cada um dos problemas até o momento de serem resolvidos com segurança. EDGAR MORIN, com o pensamento complexo, vê limites nessa especificidade. É como se víssemos todo o desequilíbrio do mundo e o dividíssemos até o momento em que percebamos certa regularidade, isso altera tanto o objeto, quanto o método de análise desse objeto: 
Um sistema fechado, como uma pedra, uma mesa, está em estado de equilíbrio, ou seja, as trocas de matéria/energia com o exterior são nulas. Por outro lado, a constância da chama de uma vela e a constância do meio interno de uma célula, ou de um organismo, não estão absolutamente ligadas a tal equilíbrio: ao contrário, há desequilíbrio no fluxo energético que os alimenta, e, sem este fluxo, haveria desordem organizacional levando rapidamente ao definhamento. (MORIN, 2006, p.21)

A grande armadilha da especialização do cientista é essa busca da regularidade e da constância. A partir da justificativa de um controle absoluto sobre o objeto de análise, reduzse o foco de visão até o ponto de vê-lo totalmente desvinculado da rede de relações a que ele pertence e, dentro dessa redução, exclui-se também o sujeito da análise e sua atuação sobre o objeto. Daí a constatação que temos, possivelmente, uma realidade inventada pelo próprio cientista.

Por outro lado, o sujeito, ao alterar seu foco de análise, ao se perceber também participante do objeto que analisa e, ao se deparar com a completa parcialidade de seu objeto fragmentado, levanta seu olhar a um novo horizonte e percebe novas formas de tratar-se com o objeto em questão.

A partir do próprio método moderno da Ciência (lógico-matemático), conclui-se que há distorções no objeto de análise e que há a necessidade de busca de um novo paradigma científico. Essa busca, ao longo do tempo, proporcionará significativas mudanças na forma com que o homem vê a si mesmo.

Não se trata de negar a História (o passado), deixando de observar ou acolher todo o conhecimento produzido pelo método cartesiano/aristotélico, afinal de contas, muito foi pensado, descoberto e construído por esse método. O que pede o bom-senso ao cientista que leva em conta as limitações da Ciência moderna é compreender que a complexidade e a presença do sujeito podem ser concebidos como a forma com que se analisa o fenômeno, não propriamente desprestigiando o método de análise, mas vendo-o como uma das possíveis verdades naquela situação de controle estabelecida.

Essa seria uma das maneiras de tentar considerar os limites da Ciência. Tal pensamento permitirá um maior intercâmbio entre as especificidades científicas, aproximará poesia de filosofia, diminuirá os preconceitos e abrirá perspectivas para novos métodos e finalidades para a Ciência, desvencilhando-a também do legado "moderno" de ela ser a única responsável pelos problemas e soluções do planeta. 
EDGAR MORIN, diferencia "racionalidade" (coerência lógica) de "racionalismo" (visão ética do racional nas ações do homem - princípio, conduta e finalidade) e de "racionalização" (coerência de uma visão total do universo a partir de dados parciais ou de um princípio único):

Contra esse princípio único, MORIN propõe a razão complexa, que "já não concebe em oposição absoluta, mas em oposição relativa, isto é, também em complementaridade, em comunicação, em trocas, em termos até ali antinômicos: inteligência e afetividade; razão e desrazão. (FERREIRASANTOS e ALMEIDA, 2012, p.126)

Tendo por princípio a "coincidentia oppositorum" opondo-se a dois princípios básicos de Aristóteles: "não contradição" e "tertium non datur" (Idem ibidem, p. 90), buscaremos nesse trabalho, diálogos entre algumas linhas de produções de conhecimento e como elas podem nos auxiliar na busca de uma das possíveis reflexões de como se constrói a identidade dos indivíduos tanto no aspecto social, quanto no imaginário.

A quebra da expectativa de uma lógica absoluta possibilita a nós a transição entre pensamentos e sentimentos, aproxima-nos do migrante quando reverte a ideia do caminho único rumo a uma solução fechada, a um único sentido da vida ou a uma essência dos seres. Traz, por outro lado, a noção de rotatividade e de sentido no trânsito, abrindo um sistema antes analítico fechado e possibilitando, nele, a contínua troca de energia.

Dessa forma, em nosso trabalho, apresentar-se-á o trânsito entre objeto e método, observandose a postura de migrantes a partir da transitividade entre fontes de conhecimento e de relação entre sujeito e objeto. 


\subsubsection{Pós-modernidade}

Eu sempre quis viver no velho mundo

$\mathrm{Na}$ velha forma de viver

O terceiro sexo

A terceira guerra

O terceiro mundo

São tão difíceis de entender.

(GESSINGER, 1986).

A noção do que entendemos por diferente, estrangeiro, desacordado da maioria, underground ou marginalizado, muito mais que nos trazer a significação ou rotulação do que precisa ser respeitado ou tolerado, deve, numa estância mais profunda, possibilitar-nos novos conceitos a serem percebidos e aprendidos.

As pessoas vistas como diferentes da maioria esperada por um grupo social trazem-nos, além de questionamentos ameaçadores aos nossos saberes ou poderes, a tarefa de soma ao nosso repertório humano, isso desde a solidariedade até a chance de novas visões e de transformação de mundo.

Se, por um lado, a ideia de perceber o outro reforça nosso próprio eu, impondo-nos limites entre a nossa subjetividade e a subjetividade alheia; por outro lado, tal percepção nos permite uma transitividade (ou mesmo até transcriação) dialógica a nos colocar integrados ao tempo, ao espaço, à coletividade:

As "identidades" flutuam no ar, algumas de nossa própria escolha, mas outras infladas e lançadas pelas escolhas em nossa volta, e é preciso estar em alerta constante para defender as primeiras em relação às últimas. Há uma grande probabilidade de desentendimento, e o resultado da negociação permanece eternamente pendente. (BAUMAN, 2005, p.19)

Antigamente, ao que parece, era mais fácil descobrirmos quem éramos no tecido social. Tínhamos uma nacionalidade, língua, religião, profissão, roupas bem definidas e determinadas, por exemplo. Com o advento das culturas e mídias de massa, da globalização e do intenso aumento do trânsito de pessoas e informações pelo planeta, as nacionalidades tornam-se porosas diante das misturas de línguas, das várias posturas religiosas dentro até de uma mesma religião, das profissões limítrofes e novas desafiando os caminhos clássicos tradicionais, enfim, das várias roupagens que temos e vivemos nas redes sociais: ei-la, a pósmodernidade ou modernidade tardia. MAFFESOLI, por exemplo, percebe nesse contínuo trânsito social um trânsito temporal, remetendo-nos a um contato com o passado arcaico: 
Pois, paradoxo que não é dos menores, essa coisa velha que é a tribo e essas antigas formas de solidariedade que são aquelas vividas no cotidiano, exercidas o mais perto possível, nascem, expressam-se, confortam-se graças às várias redes eletrônicas. Daí a definição que eu julguei da pósmodernidade: sinergia entre o arcaico e desenvolvimento tecnológico (MAFFESOLI, 2010, p.40).

A chamada modernidade tardia nos obriga o domínio de habilidades para enfrentarmos essas ambivalências advindas do contato com o outro. Em outros tempos, o "diferente" permanecia distante e intacto por fronteiras bem definidas, hoje, aporta em nossos computadores, na mídia, em nosso cotidiano, em nós mesmos, permanecendo quase todo o tempo a nos questionar e impor escolhas muitas vezes complexas e difíceis.

As velhas identidades, que por tanto tempo estabilizaram o mundo social, estão em declínio, fazendo surgir novas identidades e fragmentando o indivíduo moderno, até aqui visto como um sujeito unificado. (HALL, 2006, p. 7).

Encontra-se, nesse ponto, a noção que procuramos de identidade, sutilmente diferenciada da noção de subjetividade ou individualidade propriamente ditas. A identidade, de certa forma, é o significado que damos a nós mesmos. Sendo esse significado alicerçado pela linguagem e por nossa compreensão de mundo, ele passa pelo outro, ou seja, colocamo-nos como se fôssemos o outro para nos vermos. CIAMPA considera como sendo um processo, um "tornarse humano", trazendo-nos aqui a noção de metamorfose:

É desta forma que "tornar-se humano" constitui-se metamorfose possível pela "familização" do homem. Com base na estrutura social familiar pressupostos o trabalho social e a linguagem - é que se dá a socialização das gerações humanas, com as quais se produzem "indivíduo", sociedade e cultura, ou seja, três elementos componentes do que Habermas denomina "mundo da vida" (que se diferencia do "mundo sistêmico", ou melhor, do "sistema"). (CIAMPA, 1998, p.93)

Seguimos, dessa forma, nossa contínua procura de nós mesmos. Perdidos num labirinto de significações sociais, familiares, do trabalho e da linguagem; instintivamente, muitas vezes, fazemos um movimento de particularização, procura por nossas idiossincrasias, no entanto, quanto mais nos procuramos, mais encontramos o alheio:

O mais curioso e interessante desse processo de reinvenção simbólica encontra-se na constatação de que quanto mais nos particularizamos, mais nos coletivizamos; pois até nossas manifestações mais íntimas, únicas e instintivas nasceram de nossa memória coletiva, de nosso contato com o outro. (GIRALDES, 2011, p.103). 
Essa reinvenção simbólica vinculada à sociedade, que se constitui a partir das mídias físicas e da estrutura de poder vigente, acaba também por entrecortar-se, no terreno da linguagem, com outra forma de produção de sentido e da identidade: a mitohermenêutica.

A mitohermenêutica, por sua vez, vê o indivíduo como ente que procura a si mesmo lendopercebendo suas próprias histórias e as histórias dos outros. Como a leitura-percepção é um processo de encontro com o outro, muitas vezes, os sentidos dados são um preenchimento de significados que oferecemos ao mundo, ou seja, o mundo não é nada mais que nossos significados projetados nele:

Dizemos aqui de uma jornada interpretativa, ou seja, uma empreitada onde, segundo aquela sugestão de Ricoeur, saio de meu lugar tranqüilo e deixo meus "pré-conceitos" e "pré-juízos" (a epoché fenomenológica) e vou buscando sentido nessas obras da cultura e da arte. [...] Paradoxalmente, no mais estranho, no mais exótico, no mais distante... eu me reencontro. É a temática exposta por Heidegger no círculo hermenêutico: ao buscar o sentido das coisas percebemos que somos nós que, reciprocamente, atribuímos sentidos às coisas. (FERREIRA-SANTOS, 2005, p.68).

Percebemos, dessa forma, que há encontros entre psicanálise, teoria social, antropologia, estudos do imaginário e hermenêutica. A teoria social aproxima-se desse encontro, ao valorizar as representações sociais e as simbolizações que advêm delas: "A experiência tornase, assim, uma construção artificial, um produto gerado mais por relações e representações do que por circunstâncias, leis naturais ou casualidades". (MELUCCI, 2004. p. 14.). No entanto, a diferença crucial entre mitohermenêutica e teoria social se encontra no local de busca: enquanto os mitohermeneutas procuram a cultura identitária nas simbolizações discursivas, a teoria social a procura na estrutura sóciocultural que cerca o indivíduo:

Não é difícil concordar com o fato de que, do ponto de vista sociológico, toda e qualquer identidade é construída. A principal questão, na verdade, diz respeito a como, a partir de quê, por quem, e para quê isso acontece. A construção de identidades vale-se da matéria-prima fornecida pela história, geografia, biologia, instituições produtivas e reprodutivas, pela memória coletiva e por fantasias pessoais, pelos aparatos de poder e revelações de cunho religioso. (CASTELLS, 2010, p.23)

Tudo isso provém de indivíduos e grupos a organizarem seu sentido em função de tendências e projetos encontrados em sua estrutura social. Dessa forma, a teoria social tende a focar a estrutura social como elemento determinante enquanto os mitohermeneutas procuram o sentido que o indivíduo dá a essa estrutura social como foco principal. 
Em algumas situações, caminhos diferentes distanciam as pessoas, contudo, há momentos em que, justamente o contrário ocorre. Como nossa proposta é de construção de pontes para enriquecimento de repertório metodológico e não de caricaturar distâncias, valorizando uma cultura epistêmica em detrimento da outra, focaremos aqui muito mais os encontros que os desencontros.

Apesar de partirem de pressupostos diferentes, o objeto mitohermenêutico e o objeto identitário social são duas formas sensíveis de chegarmos a conclusões próximas: o homem, na modernidade tardia, está imerso em profundas e às vezes angustiantes buscas:

As pessoas em busca de identidade se vêem invariavelmente diante da tarefa intimidadora de "alcançar o impossível": essa expressão genérica implica, como se sabe, tarefas que não podem ser realizadas no "tempo real", mas que serão presumivelmente realizadas na plenitude do tempo - na infinitude. (BAUMAN, 2005, p.17.)

BAUMAN, ao opor o tempo real ao tempo pleno, propõe a noção de identidade a uma quase transcendência. Talvez uma das formas dessa transcendência esteja no devaneio, no poder de criação imanente em todas as pessoas:

É aqui que se pode captar a diferença entre as dialéticas da razão que justapõe as contradições para abranger todo o campo do possível e as dialéticas da imaginação que quer apreender todo o real e encontra mais realidade naquilo que se oculta do que naquilo que se mostra. (BACHELARD, 2003, p.21)

Seria ingênuo limitarmos todas as movimentações sociais e desejos humanos a uma razão lógica pronta dentro de cada um. Há outras dimensões também importantes a serem verificadas dentro dos comportamentos dos grupos de uma sociedade. No meio delas, podemos pensar na imaginação, na memória filogenética da coletividade, nos devaneios e em toda a representação que daí pode advir:

Nessa articulação de imaginação e memória, a liberdade da criação atualiza sonhos e angústias na memória da humanidade. Uma invariância dos arquétipos confere unicidade à multiplicidade de formas culturais nos espaços geográficos e nos tempos históricos através do tempo primordial. Uma imagem cósmica se impõe na percepção de nossa situação existencial e de nossa finitude. [...] Então, percebemos que, ao contrário do que há séculos nos ensinaram a pedagogia da demonstração, o conceito é um rascunho da imagem. (FERREIRA-SANTOS, 2005-A, p.50). 
BAUMAN se aproxima da plenitude simbólica da imagem quando reconhece nossa busca identitária na plenitude do tempo (infinitude), enquanto MARCOS FERREIRA percebe essa plenitude temporal projetada sobre nossa própria finitude existencial. Estamos, como sempre, ao discutirmos nossa identidade, discutindo-a ora nos nossos devaneios, ora nas funções que assumimos na estrutura social em que vivemos. Ao que parece, da mesma forma que um conceito é rascunho de uma imagem, uma identidade social traz em sua memória resquícios de um complexo arquetípico.

De um ponto de vista mais prático, como apetece aos cientistas sociais, a oposição entre arquétipo e estereótipo, por exemplo, pode ser aproximada da oposição entre identidades e papéis:

Em termos mais genéricos, pode-se dizer que identidades organizam significados, enquanto papéis organizam funções. Conceituamos aqui significado como a identificação simbólica, por parte de um ator social, da finalidade da ação praticada por tal ator. (CASTELLS, 2010, p.23).

$\mathrm{Na}$ sociedade em rede, na maioria dos atores, o significado é uma identidade primária motivadora que se desdobra em outras identidades secundárias, quanto à noção de arquétipo, segue- se o seguinte:
A imagem primordial poderia muito bem ser descrita como a percepção do instinto de si mesmo ou como auto-retrato do instinto à semelhança da consciência que nada mais é, também, do que uma percepção interior do processo vital objetivo. Do mesmo modo como a apreensão consciente imprime forma e finalidade ao nosso comportamento, assim também a apreensão inconsciente determina a forma e a destinação do instinto, graças ao arquétipo. (JUNG, 1998, p.67).

Em primeiro lugar, temos os significados em CASTELLS, uma identidade primeira organizada a partir de uma matéria bruta sócio-histórica. Paralelo a esses significados, temos o arquétipo em JUNG, uma identidade primeira organizada partindo de uma matéria bruta instintiva encontrada no cerne do indivíduo, quiçá da espécie humana. 
Em segundo lugar e opondo-se aos arquétipos e significados, temos os papéis sociais e os estereótipos, os papéis sociais organizam as funções do indivíduo e os estereótipos encerramse num consumo imediato, vazio e despersonalizado dessas funções: "Diferentemente dos arquétipos, os estereótipos são imagens descarnadas, fantasmas. Imagens feitas para consumo imediato, mas que não nutrem ninguém, pois não têm 'sustância', como diriam nossas avós". (RUBIRA, 2006, p.112).

Muito mais que nos atermos às definições propriamente ditas, cabe a nós a devida atenção aos trajetos que as constituem. Urgem estudos focados nos caminhos escondidos (veredas) tanto entre o arquétipo e o estereótipo, quanto entre os significados e os papéis sociais:

O estereótipo é um arquétipo falso, um tipo vazio, que o indivíduo, em determinados momentos, incorpora. Momentos em que a atividade densa e originária arquetípica transforma-se em fragmentos esclerosados que muitos se dispõem a seguir para conseguir reconhecimento social. (GIRALDES, 2011, p.58).

De forma insistente e quase obsessiva, pontuei as oposições entre arquétipo e estereótipo em minha Dissertação de Mestrado, RUBIRA (2006) também comentou sobre tal diferenciação. Penso, hoje, que agi daquela forma por conta da busca do percurso do herói em CAMPBELL (2009), na qual há as vicissitudes da hybris a nos distanciarem da nossa maestria apresentada por GUSDORF (2003) e do mito em si.

Tal percepção arquetípica seria um resgate de imagens de professor diluídas nos entremeios das relações com os alunos e com a própria vida, ou seja, coube-me, naquele momento, o distanciamento do estereótipo e a busca do arquétipo, um caminho que me amparou até o final do trabalho.

Todavia, hoje, por estímulo da banca de qualificação, fui pressionado a dar o passo para uma problematização maior do assunto, ou seja, deixar de fazê-lo binário (estereótipo/arquétipo) e transportá-lo para outras significações, à cata do terceiro elemento, tão falado neste processo, como se a banca me empurrasse no precipício da mesma forma que a águia empurra seus filhotes. Há como seguir no devaneio sem asas?

Talvez seja esse um dos melhores pontos no devaneio. Voamos com o olhar perdido nos ocasos e amanheceres da vida, sem asas. Voamos com o movimento de nossas imagens a se entrelaçarem com os movimentos do mundo que nos cerca. Enfim, o "trajeto antropológico" coloca em movimento essa rigidez binária primeira, vista inicialmente: 
O trajeto antropológico, ou seja, a incessante troca que existe ao nível do imaginário entre as pulsões subjetivas e assimiladoras e as intimidações objetivas, que emanam do meio cósmico e social [...] é neste intervalo, neste caminhar reversível que deve, segundo nos parece, instalar-se a investigação antropológica (DURAND, 1997, p.41).

Partindo da premissa de que o imaginário é constituído a partir da gênese recíproca advindo também da dinâmica dos arquétipos perceptível principalmente em BACHELARD (2003, p.203) adentramos ao tertium datum, à errância do nosso objeto de análise e à percepção de que arquétipo e estereótipo tocam-se como se estivéssemos numa dança, na qual, quanticamente, um influencia o outro.

Quando caminhamos numa rua ampla, pensamos que não tocamos no outro diante da hipótese de que há um vazio entre nós. No entanto, existe no mínimo (ao menos) o ar a nos contatar, ou seja, toco o outro com minha fala e até com meu olhar, da mesma forma que recebo do outro minha própria significação de mim ao olhar ou ser olhado.

Dessa forma, só existo em decorrência do outro e o outro em decorrência de mim, podendo-se transcender e migrar essa constatação social da pós-modernidade tanto para o sistema de imagens quanto para a própria linguística.

Por exemplo, numa língua, o significado de uma palavra tende a ser explicado/explicitado por outra palavra, o significado dessa segunda palavra tende a ser explicado por uma terceira e assim segue ad infinitum, No meio disso tudo, há fissuras perceptíveis, terceiros elementos que projetam a linguagem sobre seu saber ideológico (designatum) ou imaginário:

Uma situação de comunicação lingüística estabelece-se quando dois indivíduos participam do ato de fala e uma informação qualquer - um saber - transita de um para o outro. Esse ato de troca envolve não um objeto (referente ou denotatum) mas um saber (um designatum) e a única condição para que a comunicação se realize do modo mais cabal consiste na posse, pelo destinatário da mensagem de um prévio saber (implícito) sobre o saber em transmissão, possuído e realizado, no ato da fala, pelo destinador da mensagem. (LOPES, 1989, p. 49)

Um exemplo disso seria a noção de "posse", que varia de língua para língua. Há línguas indígenas, como o Tupi, em que é gramaticalmente impossível dizer: "- Minha árvore" (NAVARRO, 2006, p. 48). Isso indica, nesse caso, que há transposições e trânsitos sobre a noção de posse nos grupos sociais, que se projetam, através da língua, nos falantes. 
A linguagem deixou de ser uma forma de relatar ou transmitir com neutralidade os significados que pretendemos expressar e passou a constituílos. Dessa forma, os considerados fatos naturais, também denominados realidade, são tidos como fenômenos discursivos, cujos significados surgem a partir de jogos de linguagem e sistemas de classificação nos quais estão inseridos. E assim, o discurso não é entendido no seu aspecto lingüístico como um conjunto de palavras, mas como um conjunto de práticas que produzem efeitos no sujeito. (RUBIO, 2004, p.12)

Há, dessa forma, uma materialidade ligada ao discurso, sendo, muitas vezes, o próprio discurso interpretado como matéria, presentificação ideológica e cultural, "[...] se o sentido não é articulado na prática, ele não tem efeito.” (HALL, 2009, p.366).

Uma interessante conjunção de RUBIO (2004), HALL (2009) e DURAND (1997) se encontra em dois pontos a serem discutidos. $\mathrm{O}$ primeiro ponto refere-se à materialidade do discurso e o segundo ponto, um pouco consequência dessa materialidade, é a dinâmica do movimento perceptível através do trajeto antropológico.

Remeteremos aqui a materialidade ao princípio de transcriação tratado por CAMPOS (2013), no qual se transcende a mera tradução conteudística para uma espécie de coreografia entre línguas, ligada ao corpo e ao movimento:

A reinstituição do corpo na tradução é o que eu denomino transcriação. A reversão do impossível em possível começa por uma hiperfidelidade a tudo aquilo que constitui a significância, ou seja, às mais secretas fragrâncias do semântico pelos meandros da forma: aura que impregna a repetição de uma figura fônica; nébula que irisa a deslocação paralelizada de uma articulação sintática; pólen que se insinua num constituinte mórfico ou acompanha, volátil, um desenho prosódico que a escuta sensível capta naquele ponto messiânico onde reverbera, para além de toda a chancela etimológica, a convergência fulgurante do dessemelhante. (CAMPOS, 2013, p.106).

Como não pensar no migrante neste momento? A errância semântica, a reverberação de sons pelo caminho, a deslocação colorida polinizando os sentidos e as direções. Haroldo de Campos se inspira na "Transposição Criativa" de Roman Yakobson, na qual o tradutor possui a função de desocultar as "formas significantes" e não as "substâncias" em si nos termos de HJELMSLEV (1943).

Em outras palavras, mais grosseiramente falando, diríamos que a preocupação de Haroldo de Campos não se encontra necessariamente no que foi dito, mas nas relações sonoras e até semânticas que trouxeram aquele dizer, ou seja, transcriar é perceber e reproduzir a teia de significação que está por trás de suas palavras e não nas suas palavras em si. Há também a reflexão de Walter Benjamim na construção e constituição desse processo: 
Para captá-la [a essência da forma], será preciso optar por uma operação tradutora regida por uma noção de "fidelidade" (Treve) muito mais voltada até ao estranhamento - para a "redoação da forma" (Treve in der Wiedergabe der Form), do que submetida ao critério tradicional de fidelidade à "restituição de sentido" (Sinnwiedergabe). (CAMPOS, 2013, p.96).

Há, de certo modo, uma estratégia de inversão, na qual a restituição do sentido da forma se dá por um estranhamento original. Esse estranhamento possibilita outras compreensões do que se diz, transfere-nos de uma visão aparentemente apolínea e metafísica de busca por conceitos prontamente identificáveis para uma visão dionisíaca, vinculada ao experimento, ao processo, à vivência.

O migrante possui, imerso em si próprio esse trânsito, forçado pelo estranhamento da cultura e pela busca de transposições formais dos procedimentos de vida. Para tanto, cede seu próprio corpo. Ao vivenciar o estranho, tanto transcria o outro quanto transcria a si mesmo.

PERNIOLA se utiliza também de Walter Benjamim para tratar do conceito de Cyborg, em que essa quebra de fronteiras tão considerada aqui se recai entre o "homem" e a "coisa", ou seja, entre o que consideramos e o que não consideramos como "homem": "o homem muitas vezes se torna um objeto e o objeto possui a organicidade humana". (PERNIOLA, 2004). PERNIOLA também sugere o tertium datum como forte elemento de transposição nos rituais:

Não é necessário sermos grandes viajantes para perceber que o mundo contemporâneo oferece um panorama no qual está dissolvida a rígida contraposição entre o sagrado e o profano, entre o simbólico e o pragmático, entre o selvagem e o racional. Assistimos, de um lado, ao surgimento de comportamentos tribais nas metrópoles e, de outro, ao profundo impacto da racionalidade tecnológica e econômica nas situações menos desenvolvidas. (PERNIOLA, 2000, p.24)

Cada vez mais, parece que as fronteiras entre "espaço" e "tempo" (dois alicerces poderosos na condução da autocompreensão humana) se dissolvem: as fronteiras entre os países tornam-se mais burocráticas e menos sensíveis concretamente. O moderno, muitas vezes, revive-se com o passado (cultura vintage). PERNIOLA, dessa forma, desenvolve esse "transitar entre mundos" com os conceitos de "simulacro" e "rito sem mito", assenhorando-se da filosofia. 
Ao colocarmos este trabalho em movimento pelo passeio entre tantos teóricos que parecem estranharem-se, num giro contínuo, surgem-nos as seguintes perguntas: e se a roda parasse de girar? E se estancasse a contínua troca de pulsões do trajeto antropológico? E se as pessoas parassem de conversar umas com as outras? E se caísse em nós a consciência total dos simulacros que norteiam nossa identidade e perdêssemos até nossa própria humanidade? E se o migrante, enfim, cansado, ficasse imóvel diante da pedra encontrada no meio do caminho? O que restaria? 


\subsubsection{Identidade}

Fiz de mim o que não soube, E o que podia fazer de mim não o fiz.

O Dominó que vesti era errado Conheceram-me logo por quem não era e não desmenti e perdi-me

Quando quis tirar a máscara, Estava pegada à cara.

Quando tirei e me vi ao espelho, Já tinha envelhecido

Estava bêbado, já não sabia vestir o dominó que não tinha tirado.

(PESSOA, 1998, p.190)

Se, durante nossa caminhada, vivemos a trocar de máscaras, de histórias e de línguas; no momento em que paramos numa estalagem para pensarmos sobre nós, deparamo-nos com um imenso espelho, assustados e vazios.

Há migrantes que possuem uma quase interminável sensação de inadaptabilidade que lhes provoca a contínua busca de algum novo lugar. Tal como Ahasverus, o judeu errante, dizem para si mesmos: essa ainda não é a terra prometida, ela é mais além.

Vamos contar aqui três histórias ilustrativas para nossa pequena reflexão.

A primeira história é sobre Jacobina, personagem do conto machadiano "O Espelho". Jacobina, homem de 45 anos de origem humilde, conseguiu respeito social por conta de uma nomeação a um posto militar. Aos 25 anos, teve status social por ter sido nomeado Alferes da Guarda Nacional. Um dia, foi chamado para ir até o sítio de uma tia. Lá, para suas acomodações, oferecem-lhe um grande espelho, vindo da Família Real Portuguesa. Pouco tempo depois, sua tia sai de viagem e ele fica sozinho no sítio com os escravos. Os escravos fogem e ele fica só. Eis que Jacobina decide se olhar no espelho e vê sua imagem difusa. Perturbado, ele decide vestir sua farda e aí vê sua imagem nítida. Silêncio reflexivo...

Da mesma forma que Jacobina, no conto "O espelho" de Machado de Assis (ASSIS, 1994), a suspensão de nossa contínua viagem/troca social nos faz perceber que nossas máscaras somos nós mesmos e o vazio nos abraça em dilemas bem difíceis:

Cada criatura humana traz duas almas consigo: uma que olha de dentro para fora, outra que olha de fora para dentro [...] a alma exterior pode ser um espírito, um fluido, um homem, muitos homens, um objeto, uma operação [...]. Está claro que o ofício dessa segunda alma é transmitir a vida, como a primeira: as duas completam o homem, que é, metafisicamente falando, uma laranja. (ASSIS, 1994, p.81) 
Para Jacobina, perder uma das metades da laranja é perder metade da existência. A alma exterior muda de natureza e de estado e, quando ele se vê sem sua máscara de Alferes, nota o esquecimento de si mesmo ao ver o espelho difuso. O espelho, visto nesse conto de Machado de Assis, tão ilustrado, simbolizado e constituído na cultura moderna dita civilizada, reflete-se em vários campos de estudo, desde a psicanálise lacaniana até literatura roseana e nos ajuda a notar que precisamos olhar para fora para procurarmos o que temos por dentro, vazios refletindo-se a si próprios.

A segunda história, quem nos conta é Clement Rosset.

Clément Rosset, na manhã de 28 de janeiro de 1998, teve um sonho, no qual explica para um círculo de conhecidos que sua identidade oficial é apócrifa, um resumo de uma estranha sucessão de coincidências, confusões, mal entendidos e erros, seu nome não é o seu nome, sua idade não é a sua idade:

Este sonho (como o senso comum, por sua vez) admite de início como evidente haver uma diferença entre identidade social e identidade pessoal (ou identidade íntima do "eu", ou identidade psicológica, ou identidade real); distinção que, de minha parte, sempre tende a considerar suspeita e inclusive a espontaneidade recusar, seguindo, desse modo, pensadores como Montaigne e David Hume (o qual, diga-se de passagem, serve para ilustrar o feito bem sabido de que se pode sonhar não só contra a lógica mas também contra o próprio pensamento (ROSSET, s.d., p.10). ${ }^{1}$

Há momentos em que nos desprendemos do bombardeio externo de traços e características que a sociedade nos dá. Alguns deles podemos perceber como sendo o alferes solitário na fazenda diante do espelho, ou o sonho de Clément Rosset, ou quando um migrante interrompe sua travessia numa hospedaria: A identidade pessoal é um hóspede familiar, mas também um hóspede invisível, ou visível a partir de um ângulo de visão que me impede de olhá-lo na cara e identificá-lo de maneira precisa. (ROSSET, s.d., p.33) ${ }^{2}$

A terceira história é de Zygmum Bauman.

Numa entrevista a Benedetto Vecchi, Zygmunt Bauman conta que, de acordo com um costume na Universidade de Charles, em Praga, toca-se o hino nacional da pessoa que está recebendo o título de doutor honoris causa. Quando chegou a vez de Bauman, perguntaramlhe se ele escolheria o hino da Grã-Bretanha ou da Polônia.

\footnotetext{
${ }^{1}$ Tradução de Samea Ghandour.

2 Tradução de Samea Ghandour.
} 
A Grã-Bretanha foi o país que escolhi e pelo qual fui escolhido por meio de uma oferta para lecionar, já que eu não poderia permanecer na Polônia, país em que nasci, pois tinham me tirado o direito de ensinar. Mas lá, na GrãBretanha, eu era um estrangeiro, um recém-chegado - não fazia muito tempo, um refugiado de outro país, um estranho. (BAUMAN, 2005, p.15).

Ele pediu que fosse tocado o Hino Europeu. Misto de exclusão e inclusão, terceira via, algo que abraçava suas duas identidades ao mesmo tempo em que as esvaziava também quando não elucidava as diferenças, as particularidades de cada país. Parar no meio da estrada diante da pedra no caminho é contemplar-se no espelho, pedra parada no tempo e no espaço, que, ao nos localizar dentro de um fluxo sociocultural externo, deslocaliza-nos nos nossos fluxos internos de existência.

Da mesma forma que não conseguimos contemplar o sol diretamente, pois nos cegaria, observamos nossa identidade de soslaio. Isso nos pede o trânsito, o transporte, a travessia, a transcriação. No entanto, nossos sonhos, espelhos e hospedarias nos incomodam com o fantasma do vazio a nos atormentar, a imensa e fatídica "realidade" ergue-se imensa sobre nós, verdade estática e cruenta a assolar nossa condição existencial do mundo.

A convivência com o incômodo do vazio faz com que tenhamos vários procedimentos de enfrentamento. ROSSET (2008) trata quase didaticamente desse assunto: há os que recusam a realidade radicalmente (suicídio), embora haja a constante dúvida se existe outro mundo e outra realidade pior que a nossa; há os que suprimem o real com a alienação mental (loucura); há os que se propõem a uma cegueira voluntária (drogas). No entanto, o mais comum é algo um pouco diferente do levantado no início deste parágrafo.

Se o real me incomoda e se desejo livrar-me dele, me desembaraçarei de uma maneira diferente mais flexível, graças a um modo de recepção do olhar que se situa a meio caminho entre a admissão e a expulsão pura e simples: que não diz sim nem não à coisa percebida, ou melhor, diz a ela ao mesmo tempo sim e não. (ROSSET, 2008, p.15)

Por exemplo, vamos supor que eu tenha um ente querido bem mais velho que eu. É esperado o momento em que irei deixar de tê-lo comigo e isso pode parecer assustador demais. Quando me perguntarem sobre o assunto, digo sim ao fato, aceito que ele vai me deixar um dia, mas digo não às consequências desse fato e sigo minha vida como se ele (e, consequentemente eu, fôssemos eternos): vivemos como se nunca fôssemos morrer e morremos (momento trágico) como se nunca tivéssemos vivido, ou melhor, vivemos como se tivéssemos identidades, certezas e motivos definidos e morremos como se tivéssemos muita coisa ainda que se fazer para sermos alguém. 
Criamos outra realidade para suportarmos melhor a nossa falta de sentido.

De novo, o olhar de soslaio, no meio do caminho, tertium datum, o que Clément Rosset chama de ilusão ou o duplo do real, perceptível na dinâmica da estrutura dos oráculos, na metafísica platônica, enfim, nas metades da laranja machadiana, constituindo um "eu" duplo "idêntico" ao primeiro:

A angústia de ver desaparecer o seu reflexo está então ligada à angústia de saber que se é incapaz de demonstrar a sua existência por si mesmo: a última prova, a prova pela própria coisa, que se pensava guardar como trunfo decisivo é para sempre inoperante (ROSSET, 2008, p.113).

Há momentos em que topamos com a própria existência em si, que não está segura ou garantida em elementos externos a ela, sejam oraculares, metafísicos ou meramente sociais. Esses momentos perpassam por nós vez por outra em nossas vidas: algumas vezes, dizemos que somos surpreendidos pelo destino; outras, simplesmente, seguem nossos olhos estáticos ou extáticos diante na contemplação do nada:

O Sr. Ninguém, pai espanhol de nenhum, possui senhoria, ventre, honra, conta no banco e fala com voz forte e segura. O Sr. Ninguém enche o mundo com sua vazia presença. Está em toda a parte e em todos os lugares tem amigos. É banqueiro, embaixador, homem de empresa. Passeia por todos os salões, é condecorado na Jamaica, em Estocolmo e em Londres (PAZ, 1992, p.44). 


\subsection{Amor Fati}

Melhor destino que o de conhecer-se Não frui quem mente frui. Antes, sabendo,

Ser nada, que ignorando:

Nada dentro de nada.

Se não houver em mim poder que vença

As parcas três e as moles do futuro,

Já me dêem os deuses

O poder de sabê-lo;

E a beleza, incriável, por meu sestro,

Eu goze externa e dada, repetida

Em meus passivos olhos,

Lagos que a morte seca.

(PESSOA, 1990, p.200)

O pertencimento e fruição em si das coisas do mundo talvez esteja na consciência de que jamais desfrutaremos, efetivamente, do que nunca, sequer, nosso foi. E o destino o tempo todo nos alicerça disso, vide a frase sussurrada quase sempre em velórios: “-nós não somos nada."

Uma possível leitura estoicista do poema epigrafado está no gozo pela passividade de um carpe diem às avessas, no qual nos distanciamos dos sentimentos diante da efemeridade nossa.

A implícita busca de como nos tornamos o que somos advinda de Píndaro e tão tratada por Nietzsche advém da constatação de que ainda não somos nós mesmos. Isso provém de lacunas, falhas, contratempos existenciais interpretados aqui na metafísica, nos oráculos, nos sonhos, nos espelhos, enfim, na criação de outras realidades para tentar darmos conta de alguma realidade inicial que ainda não encontramos. Uma realidade que, possivelmente, jamais encontraremos em sua totalidade, uma vez que, por esse raciocínio, nós próprios estamos em contínuo movimento, ou seja, tornar-se a si próprio é uma utopia, um jogo já perdido desde o início da batalha.

Diante disso, Nietzsche se propõe um desafio, não perguntando qual o sentido da vida mas se ela possui, de fato, algum sentido. Seria necessário estar fora da vida para conhecer o seu valor, mas, ao morrermos, não avaliamos esse sentido, pois, a avaliação efetiva já é o próprio viver.

Ao deparar-se com a falta de sentido (alegórica morte de Deus e as consequências disso) caímos no dilema: ou sofremos com o non sens, olhar de horror diante do sem sentido (horror fati); ou nos propomos à redenção do sofrimento pela criação, o saber trágico ou dionisíaco, a nossa proposta de sentido para a vida, aceitando o jogo do sem sentido: 
Minha fórmula para a grandeza no homem é amor fati. Não querer nada de diferente, nem para a frente, nem para trás, por toda a eternidade... Não apenas suportar aquilo que é necessário, muito menos dissimulá-lo - todo idealismo é falsidade diante daquilo que é necessário - mas sim amá-lo". (NIETZSCHE, 2013, p.61).

Precisamos da ausência de acréscimos morais ou motivações metafísicas, numa inocência tal como as crianças e os artistas. As crianças brincam pela própria brincadeira em si. Tudo isso nos remete ao universo da aprendizagem:

Diante do trágico, há três escolhas existenciais possíveis, escolhas de ordem pedagógica, pois modificam o próprio modo como a vida é vivida: ou se escolhe recusá-la integralmente, o que significa a opção pelo suicídio,ou se escolhe aprová-la provisoriamente, sob determinadas condições, o que significa opção pela ilusão; ou se escolhe aprová-la integralmente, escolha trágica, que aceita a existência como se apresenta, com sua efemeridade, instabilidade, insignificância, com seus artifícios, suas possibilidades, suas convenções, enfim, o que é dado a viver (ALMEIDA, 2013, p.1013).

O gozo, a alegria de um saber, de um viver (apesar de provisório) pode ser encontrado na criança, no artista em sua performance ou criação, em jogos, nos quais as pessoas vivem cada segundo, mesmo conscientes de que fenecem e, em si mesmos, nada representam, cabendolhes apenas os louros da vitória ou o amargor da derrota, efêmeros também, pois logo poderão ser diferentes no próximo jogo.

Entendendo o suicídio como a negação da verdade, temos o outro lado, no qual a aprovação é condicionada à percepção de que vejo e legitimo a verdade, porém, não vejo e legitimo os efeitos dessa verdade, isso se relaciona com o duplo da realidade de Clément Rosset: a ilusão. O espírito trágico, em Nietzsche, pedagogiza-nos quando, tal como éramos quando crianças, vivemos as experiências sempre como primeiras, sem motivos, moral ou metafísicas:

A criança é, em Nietzsche, origem, começo absoluto. E a origem está fora do tempo e da história. $\mathrm{O}$ artista busca sua própria infância porque deseja a possibilidade pura. E busca também devolver a infância à matéria com que trabalha, à palavra, no caso do poeta. $O$ poeta quer que as palavras recuperem sua primitiva inocência, à margem ou aquém das contaminações às quais as submeteu a uso dos homens. (LARROSA, 2009, p.102).

Todas essas imagens podem ser entrecortadas com a do viajante, como se ele fosse uma criança no país que o recebe: precisa ser alfabetizado na nova língua, conhecer os costumes locais, deslumbrar-se diante de coisas banais para os habitantes do local, bem como estranhar deveras outras atitudes: 
A figura do viajante, do expectador errante, do homem que atravessa o mundo sem formar parte dele, daquele que está entre nós, mas que não é um de nós, permite a Nietzsche contemplar o rebanho a partir do exterior, apontá-lo com o dedo e qualificá-lo com esses dois atributos, a preguiça e a covardia, que vão servir imediatamente de negativo, de fundo acinzentado, para destacar, como exigência, seus antônimos. (LARROSA, 2009, p.48).

É oportuno, em alguns instantes, fazermos o inverso, ou seja, não comentarmos sobre o migrante e imaginar, justamente, o que o migrante comentaria de nós. Nietzsche, com essa alegoria, percebe: somos preguiçosos e covardes, escondemo-nos atrás de nossos costumes e opiniões. Há, além disso, a possibilidade de transcendência de significado do viajante para o andarilho, uma vez até que muitos migrantes mantêm, cada um da sua forma, a chama acesa do caminhar errante que lhes propicia a eterna viagem.

Quem alcançou em alguma medida a liberdade da razão não pode se sentir mais que um andarilho sobre a terra - e não um viajante que se dirige a uma meta final: pois esta não existe. Mas ele poderá e terá olhos abertos para tudo quanto realmente sucede no mundo, por isso não pode atrelar o coração com muita firmeza a nada em particular; nele deve existir algo de errante, que tenha alegria na mudança e na passagem. (NIETZSCHE, 2005, p.271).

Haverá, ao andarilho, noites ruins, com o portão da cidade e as aduaneiras fechadas; noites ao relento, porém, terá a contemplação das estrelas e o vigor do devaneio a seu lado. Haverá também sempre alguém (talvez preguiçoso, talvez covarde) a querer escutar suas histórias e ser como ele.

Sim, ele terá suas recompensas: a filosofia da manhã, o trânsito dos pensamentos, a errância dos afetos e o espírito incerto da aventura; armas para dançar e esgueirar-se diante dos problemas da existência, na maioria das vezes, criados pelas filosofias das cidades e habitações fixas e não pelas estradas. 


\subsection{O Andarilho e o Rio}

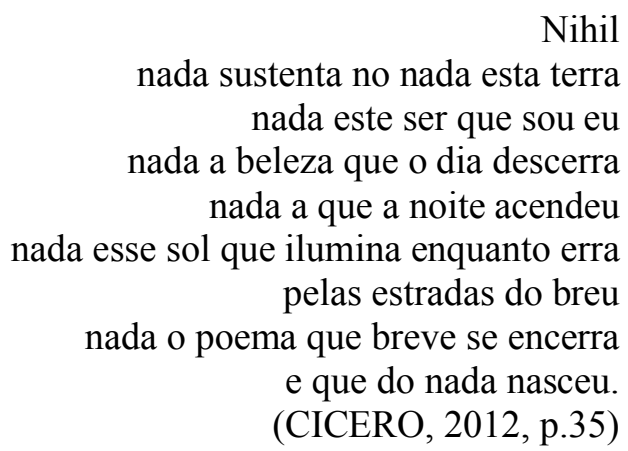

Podem nos dizer que há milhões de alternativas na vida a serem escolhidas, no entanto, todas elas envolvem convenções já produzidas pelos outros a direcionarem nossa escolha. Por exemplo: “- você pode ser médico, advogado, engenheiro...” Por trás dessa pretensa liberdade, há uma forte imposição que permeia quase a falta da escolha. É como se nós, nos dias de hoje, tivéssemos desaprendido as escolhas mais simples e essenciais com que tínhamos proximidade quando éramos crianças.

A busca dessa escolha mais profunda pode pressupor a falta completa de significações na vida: paradoxalmente, só é realmente livre quem percebe que não tem, efetivamente, nada a escolher. Trata-se aí da escolha "ativa" atrelada ao processo de criação de caminhos. Parece que só diante do "nada" que algo realmente iluminador pode surgir, que uma experiência mais efetiva pode ser vivenciada. Quando não conseguimos enxergar sentido algum em algo, cabe exclusivamente a nós a responsabilidade de lhe assegurar um sentido, daí advém nossa liberdade.

Entendemos esse encontro com o sem sentido (nada) como sendo a experiência do "espírito trágico" nos termos de NIETZSCHE e de CLÉMENT ROSSET. Ambos tratam da experiência humana com a falta de sentido da vida e do mundo, com sua desconcertante desorganização, com a constatação de uma vacuidade de motivos e sentidos metafísicos existenciais:

A sabedoria dionisíaca ou trágica é a que, diante da constatação do semsentido da existência e do desespero subsequente, afirma a posição do homem enquanto instrumento da vida, como criador de valores e produtor de sentido (BILATE, 2011, p.52). 
De certa forma, NIETZSCHE reconhece o quanto a vida pode ser sofrida, porém, ao contrário de uma tradição niilista schopenhauriana, busca dizer sim à vida como ela é, amá-la, vê-la como bela sem buscar nela transcendências metafísicas ou sentidos próprios e absolutos.

Tal postura diante do mundo pode nos tirar muitas vezes o sono. Tal como um leão que esteve a vida inteira acorrentado à jaula e não sabe o que fazer quanto lhe tiram as correntes, para nós é praticamente impossível não interpretar, não dar um valor ou uma convenção prévia ao mundo que conseguimos enxergar ou à nossa própria existência. No entanto, muitos de nós, em poucos, ou em muitos momentos, entramos, cada um à sua forma, em contato com esse lado trágico de nossas percepções, com essa falta de sentido. É justamente isso que procuraremos ilustrar nesse momento partindo do conto $A$ terceira margem do rio de GUIMARÃES ROSA (ROSA, 1988) (ANEXO A):

NOSSO PAI era homem cumpridor, ordeiro, positivo; e sido assim desde mocinho e menino, pelo que testemunharam as diversas sensatas pessoas, quando indaguei a informação. Do que eu mesmo me alembro, ele não figurava mais estúrdio nem mais triste do que os outros, conhecidos nossos. (p.32)

Nas primeiras palavras do conto, já temos um narrador procurando encontrar sentido em alguma transformação: "NOSSO PAI era homem cumpridor". O verbo no pretérito imperfeito do indicativo nos mostra a afirmação de um fato perfeito no passado que deixou de sê-lo, como, se hoje, esse PAI não fosse nem ordeiro, nem positivo e, pior, fosse estúrdio (estranho e desajuizado).

Outro elemento bem interessante é "NOSSO PAI" escrito em "CAIXA ALTA". É certo que todos os inícios dos contos desse livro também o são, mas, contaminados por uma hermenêutica nietzschiana, diante de uma moral cristã em que expressões ligadas a Deus são escritas em "CAIXA ALTA"; esse PAI pode supor-se como aquele que cria um mundo ordenado (DEUS) e que, sem motivo aparente, morre ou desajuíza-se. Há até um momento no conto em que, tal como um padre ou propriamente DEUS, esse PAI abençoa o filho: "Ele só retornou o olhar em mim, e me botou a bênção, com gesto me mandando para trás” (p.33).

Deu-se que esse PAI, certo dia, mandou fazer para si uma canoa e, quando a canoa ficou pronta, partiu: "Nosso pai não voltou. Ele não tinha ido a nenhuma parte. Só executava a invenção de se permanecer naqueles espaços do rio, de meio a meio, sempre dentro na canoa, para dela não saltar, nunca mais” (p.33). 
"A estranheza dessa verdade deu para estarrecer de todo a gente. Aquilo que não havia acontecia" (p.33). O verbo "haver" em português possui grande beleza, em seu campo semântico, significa “existir”, “acontecer”, "presentificar”, "realizar-se”. Supõe-se, no conto, uma sutileza conotativa de que isso não poderia "ocorrer" porque não "havia", ou seja, não há possibilidade alguma de ocorrer algo que, em sua essência, não existe, como se surgissem bolinhas de gude dentro de um vidro hermeticamente fechado, por exemplo. Temos, então, um momento em que todos entram em contato com o "trágico", o desconcerto, a falta de sentido das coisas no mundo.

Algo similar ocorreu quando Anaximandro de Mileto agarrou de forma ousada um dos mais significativos problemas éticos: "Como pode perecer algo que tem direito a ser?" (NIETZSCHE, 2012, p.51). Em termos cristãos, poderíamos pensar: "Como pode DEUS não existir ou como pode DEUS perder o juízo?

Segue-se, no conto, uma angustiante busca de motivações e explicações lógicas para o PAI ter agido daquela forma, todas elas vinculadas a convenções:

Nossa mãe, vergonhosa, se portou com muita cordura; por isso, todos pensaram de nosso pai a razão em que não queriam falar: doideira. Só uns achavam o entanto de poder também ser pagamento de promessa; ou que, nosso pai, quem sabe, por escrúpulo de estar com alguma feia doença, que seja, a lepra, se desertava para outra sina de existir, perto e longe de sua família dele. (p.33)

Possíveis explicações racionais: doideira, pagamento de promessa, lepra. Pela lógica, segundo a mãe e os aparentados, a comida na canoa acabaria e o pai voltaria. Todavia, também sem explicação alguma, o próprio narrador deixava comida para o pai num oco de pedra do barranco sem que ninguém percebesse e com a anuência tácita da mãe. Alguns chegaram até a pensar que o pai era Noé e que tinha antecipado a canoa para um futuro dilúvio em razão das muitas chuvas que caíram em um determinado período.

O motivo é que, enquanto a metafísica é incapaz de expressar o mundo, em seu espírito trágico, pela prevalência que concede à verdade em detrimento da ilusão, ou pela oposição que estabelece entre a essência e a aparência, na arte, a experiência da verdade se faz indissoluvelmente ligada à beleza, que é uma ilusão, uma aparência; enquanto o espírito científico - a crença na penetrabilidade da natureza e na virtude da panacéia do saber - acredita que o pensamento, seguindo o fio da causalidade, pode conhecer o ser em seus abismos mais longínquos ou até mesmo corrigi-lo, curar a ferida da existência, a experiência trágica, com sua música e seu mito, é capaz de justificar a existência do "pior dos mundos", transfigurando-o. (MACHADO, 2001, p.1) 
O problema central se encontra na distância entre o conceito e a palavra poética, ou seja, o trágico não pode ser expresso conceitualmente, o saber racional ou metafísico nega o trágico, o conceito é uma palavra esclerosada do objeto que representa. A grande reviravolta de NIETZSCHE está em demonstrar que tanto a ciência e sua lógica quanto a religião não são capazes de conhecer ou curar a ferida mais profunda de nossa existência.

De qualquer forma, diante da falta de respostas do pai que se escondia dos outros facilmente nos entremeios do rio ("nosso pai se desaparecia para a outra banda, aproava a canoa no brejão, de léguas, que há, por entre os juncos e mato, e só ele conhecesse, a palmos, a escuridão daquele"p. 34), diante da falta de respostas da religião ou da lógica discursiva da vida, simplesmente nosso sofrido narrador diz:

A gente teve de se acostumar com aquilo. Às penas, que, com aquilo, a gente mesmo nunca se acostumou, em si, na verdade. Tiro por mim, que, no que queria, e no que não queria, só com nosso pai me achava: assunto que jogava para trás meus pensamentos. (p.34)

A identificação com a solidão do pai, a recorrente tentativa em parar de pensar naquilo e o silêncio contínuo tomaram conta do conto. A mãe jurou muito contra a ideia e o PAI "nada não dizia". Aliás, o pai não diz uma palavra no conto inteiro e até nosso narrador e sua família economizam por demais as palavras, principalmente depois da partida "Nós, também, não falávamos mais nele. Só se pensava. Até o rio era silencioso: “o rio por aí se estendendo grande, fundo, calado que sempre” (p.32). O silêncio contínuo:

O único vínculo entre os homens é o vínculo que não se diz; os homens serão sempre uns para os outros companheiros de silêncio. Um homem começa a se compreender unicamente quando deixa de falar e somente uma motivação é suficiente para nos fazer deixar de falar: a revelação do trágico. (ROSSET, 2010, p.65)

O narrador do texto, ao contemplar com palavras o silêncio das pessoas de sua história, contempla o trágico em sua essência. Embora o silêncio permanecesse, de quando em quando, a memória despertava todos desse esquecimento e a contemplação do trágico se repetia:

E nunca falou mais palavra, com pessoa alguma. Nós, também, não falávamos mais nele. Só se pensava. Não, de nosso pai não se podia ter esquecimento; e, se, por um pouco, a gente fazia que esquecia, era só para se despertar de novo, de repente, com a memória, no passo de outros sobressaltos. (p.35) 
O maior dos pesos. Primeiramente, em A Gaia Ciência, NIETZSCHE escreve sobre "O Eterno Retorno" não como uma teoria física, não como uma explicação cientificista da circularidade do tempo, mas sim como uma mera possibilidade, uma espécie de dilema ético:

\begin{abstract}
E se um dia, ou uma noite, um demônio lhe aparecesse furtivamente em sua mais desolada solidão e dissesse: "Esta vida, como você a está vivendo e já viveu, você terá de viver mais uma vez e por incontáveis vezes; e nada haverá de novo nela, mas cada dor e cada prazer e cada suspiro e pensamento, e tudo o que é inefavelmente grande e pequeno em sua vida, terão de lhe suceder novamente, tudo na mesma sequência e ordem - e assim também essa aranha e esse luar entre as árvores, e também esse instante e eu mesmo. (NIETZSCHE, 2011, p.230)
\end{abstract}

De um lado, poderíamos amaldiçoar o demônio, de outro lado chamá-lo de DEUS. Mas o mais forte de tudo isso é o quanto precisaríamos estar felizes conosco e com nossa vida para não desejar nada além dela mesma. Da mesma forma que a imagem do "Eterno Retorno" se envolve com a contemplação do trágico, o narrador sempre voltava a contemplar a escolha sem explicação que o pai fez da própria vida. Onde estará o nosso Eterno poder de criação para suportar a repetição da contínua contemplação da tragédia do sem sentido da vida?

Minha irmã se casou [...] Às vezes, algum conhecido nosso achava que eu ia ficando mais parecido com nosso pai. Mas eu sabia que ele agora virara cabeludo, barbudo, de unhas grandes [...] minha irmã teve menino [...] minha irmã se mudou, com o marido para longe daqui. Meu irmão se resolveu e se foi, para uma cidade. Os tempos mudavam, no devagar depressa dos tempos. Nossa mãe terminou indo também, de uma vez residir com minha irmã, que estava envelhecida [...] Eu permaneci, com as bagagens da vida. (p.35)

Segue-se o "Eterno Retorno" figurando-se na eterna viagem cíclica dos rios. Todos parecem ir-se como o pai. Tudo parece mudar embora o narrador fique imóvel, com as bagagens da vida. Embora o narrador não tenha se mudado, possuía bagagens, como se fosse um eterno viajante que Eterno retorna, espelho do pai a viajar internamente à cata de uma terceira margem do rio, retornando a si mesmo, sempre. A água aqui tem um sabor interessante. Possivelmente um viajante de mares e oceanos tem imagens muito mais ligadas ao "ar" e à descoberta de mundos novos, enquanto o viajante do rio parece ficar imerso entre "terras" e possíveis raízes para se amparar.

BACHELARD (2001, p.127) percebe em NIETSZCHE uma imaginação material ligada ao ar. No entanto, aqui, diante do retorno, do rio, das águas, pensamos em refletir um pouco sobre como a água dos rios constrói nosso contato mais íntimo diante de nossa existência: 
E o sonhador, diante do riacho, pensa em seres que entregariam "a Deus sua existência pouco a pouco, esgotando devagarinho sua substância até a morte, como essas árvores entregam suas sombras uma após a outra. $\mathrm{O}$ que a árvore que se esgota é para a água que lhe bebe a sombra e se faz mais negra com a presa que engole a vida da Fada não seria a mesma coisa para a morte que lhe traga?".

Esgotar-se lentamente: "Os tempos mudavam no devagar depressa dos tempos" (p.35). A água nos traria a imagem de uma morte profunda, lenta e melancólica. O pai não é aquele que está conosco, mas também não é aquele que se foi completamente. Trata-se de um "ir-se" em formação contínua, algo similar à angústia existencial.

Segundo GILBERT DURAND, a angústia existencial é a certeza de que um dia deixaremos de existir, morreremos, realidade trágica com quem temos que conviver todos os dias, é essa mesma angústia o motivo para criarmos o regime de imagens de enfrentamento da vida (DURAND, 1997, p.63).

Não se encontravam explicações para o feito do pai, que permanecia lá, no rio. Sem entender como, o narrador se sentia culpado pela ausência do pai. Seguiu-se assim até o momento em que o próprio narrador tomou uma atitude "estúrdia" e gritou ao pai o que lhe urgia:

"Pai, o senhor está velho, já fez o seu tanto... Agora, o senhor vem, não carece mais... O senhor vem e eu, agora mesmo, quando que seja, a ambas vontades, eu tomo o seu lugar, do senhor, na canoa!" E, assim dizendo, meu coração bateu no compasso mais certo. (p.36)

Podemos entender esse momento como uma afirmação positiva diante dos acasos da vida, do trágico e do próprio demônio do "Eterno Retorno". "O coração bate no compasso mais certo" ou "Eu estava muito no meu sentido" quando ocorre, por alguns momentos, a desistência em se compreender a falta de sentido da vida e se dispor a vivê-la, tal como ela é.

Um dizer sim sem reserva, até mesmo ao sofrimento, à própria culpa, a tudo o que é problemático e estranho na existência... Este sim derradeiro, entusiasta exuberante e folgazão à vida não é só o mais excelso discernimento, é também o discernimento mais profundo, o mais rigorosamente confirmado e sustentado pela verdade e pela ciência. (NIETZSCHE, 2008, p. 54)

\footnotetext{
${ }^{3}$ CLAUDEL, Paul. Les cinq grandes odes. p. 65 apud BACHELARD, 2002, p.57.
} 
Só quando a coragem nos atiça parece que, efetivamente, aproximamo-nos da verdade. Temos nessa parte do conto um momento real e verdadeiro em que o narrador muda sua forma de experiência de mundo ao deixar de questionar os motivos pelos quais o pai fez o que fez e, simplesmente, também sem motivo algum, se dispõe a fazê-lo.

O pai, então, escuta, saúda com um gesto, fica de pé, maneja o remo em direção ao filho, concordando. O filho treme profundamente, foi o primeiro gesto depois de tantos anos de silêncio. O filho não podia... e foge, e hoje pede perdão:

Sofri o grave frio dos medos, adoeci. Sei que ninguém soube mais dele. Sou homem, depois desse falimento? Sou o que não foi, o que vai ficar calado. Sei que agora é tarde, e temo abreviar com a vida, nos rasos do mundo. Mas, então, ao menos que, no artigo da morte, peguem em mim, e me depositem também uma canoinha de nada, nessa água que não pára, de longas beiras: e, eu, rio abaixo, rio a fora, rio a dentro - o rio. (p.37)

Mesmo tendo plena consciência de que, nesse momento, não deveríamos dizer nada porque nada deve ser dito, precisamos ainda nos acalentar com esta pequena tábua de salvação diante do mar da existência que nos são as palavras. Se o pai se encontrasse com o filho, o melhor seria que ambos permanecessem em silêncio dentro da canoa observando o rio esvair-se. Por outro lado, se, nos modelos dos filmes hollywoodianos, houvesse uma brilhante explicação, seja metafísica ou o destrinchar-se do nó do enredo do conto; todo o contato com o espírito trágico se esclerosaria.

Os mistérios, as ambiguidades dos oráculos, o acaso se abatendo sobre nós são o que mantém a esperança de que algo novo possa ser criado no nosso mar de convenções e de escolhas já prontas, pelo fato de eles, ao fugirem das explicações lógicas, colocarem-nos diante do vazio da vida e do grande dilema de dizer "sim" ou "não" a ele. Por alguns momentos, o filho disse "sim" à vacuidade de sentido da vida e foi capaz de passar por uma experiência que nenhuma outra personagem do conto passou: o efetivo jogo da existência. É nesse aspecto que a Pedagogia da Escolha se torna uma postura interessante a ser adotada diante da vida e do que entendemos por Educação:

Do ponto de vista existencial, não há nenhuma escolha a se fazer. Não escolhemos nascer, onde, quando e como nascer, em que condições materiais ou familiares vamos nascer, com quais características físicas, com que carga genética, nada. Também não escolhemos morrer; a finitude de nossa existência individual nos é dada de modo trágico, destituída de finalidade, impossível de ser escolhida. Até mesmo a consciência não é uma escolha, mas algo que descobrimos existindo. Não posso ter outra consciência a não ser a consciência que tenho de minha consciência. (FERREIRA-SANTOS e ALMEIDA, 2012, p.154) 
Apesar disso tudo, essa falta de escolhas nos impõe uma única escolha: aceitar ou não nossa vida como ela é. Quem não aceita fica eternamente buscando explicações ou fugas que vão além dessa vida, em outras vidas ou planos. Quem aceita esse jogo da vida sem racionalizações, tal como uma criança acha graça em brincar sem precisar de motivações, dá como passo uma primeira escolha que trará todas as demais escolhas:

Essa primeira escolha é a base de todas as demais escolhas. Se não escolhemos existir, escolhemos, no entanto, ao longo da existência. E são os caminhos eleitos que perfazem a jornada, a trajetividade da vida. É por isso que a educação deve, menos que preparar para as decisões que vão acontecer em determinados momentos da vida, ocorrer como escolha (FERREIRASANTOS e ALMEIDA, 2012, p.154).

São as escolhas que fazemos que, na verdade, formam-nos. Aprendemos e nos Educamos o tempo todo e não apenas em alguns momentos da vida. Há a escolha mais profunda, existencial em cada pequeno momento, é ela os alicerces de todas as nossas demais escolhas, de certa forma, é elas que constroem para nós uma postura diante de vida, do que somos em conjunção com os outros.

A escola instituída nos atuais moldes de percepção conteudística e racionalizante, envolvida na preparação de técnicas para o mercado de trabalho ou de técnicas para o vestibular, comporta-se da mesma forma que a família do narrador do conto procurando encontrar lógicas em pequenos pedaços de vida e demonstrá-los exaustivamente aos alunos. Os alunos, por sua vez, consideram quase tudo aquilo uma grande chatice e muitos ridicularizam todo aquele sentido constituído na lousa, que não possui sentido algum na suas próprias existências.

Apesar disso, pode-se seguir A Pedagogia da Escolha nos momentos de "distração" em que nos permitimos perceber as experiências descompromissadamente, ou seja, naqueles momentos em que fugimos aos sistemas ou livros didáticos e que estabelecemos a "Razão Sensível” (FERREIRA-SANTOS, 2005, p.48), a relação "Mestre-aprendiz" (GIRALDES, 2011) ou a "Arte-Educação" (FERREIRA-SANTOS e ALMEIDA, 2012, p.154), dentre outros. Por fim, há que se pensar também que a Educação desse ponto de vista mais profundo e existencial ocorre também além da escola, no cotidiano, nas viagens que fazemos eternamente pelos rios de nossa vida: "Digo: o real não está na saída nem na chegada. Ele se dispõe para a gente é no meio da travessia" (ROSA, 2001, p.80). 
Ao que parece, a terceira margem do rio é o caminho, o curso; esse pai pode ser o andarilho e o andar sem destino é o desfrutar do caminho da vida por si só, sem espera de onde poderíamos chegar, ou de elementos transcendentes ao próprio caminho:

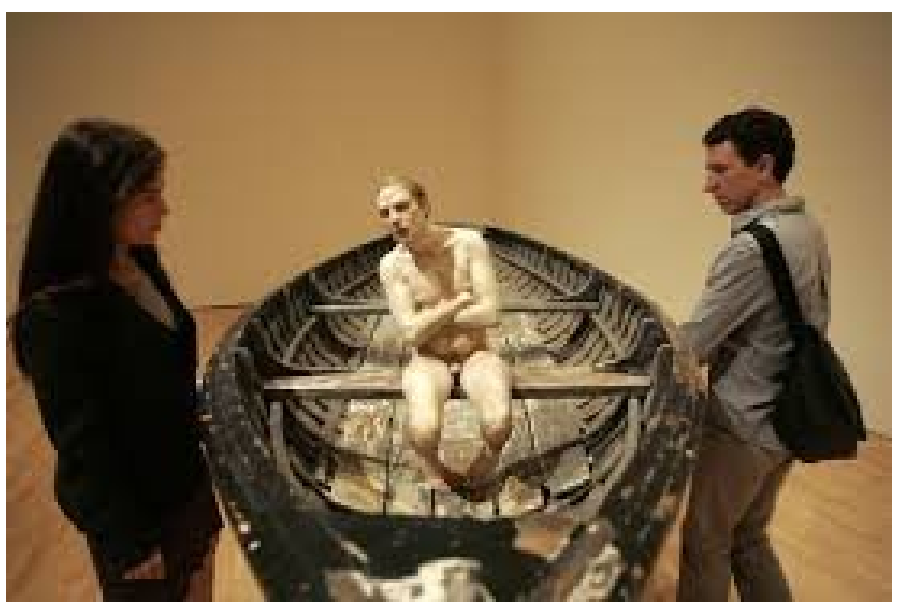

(MUEK, 2002)

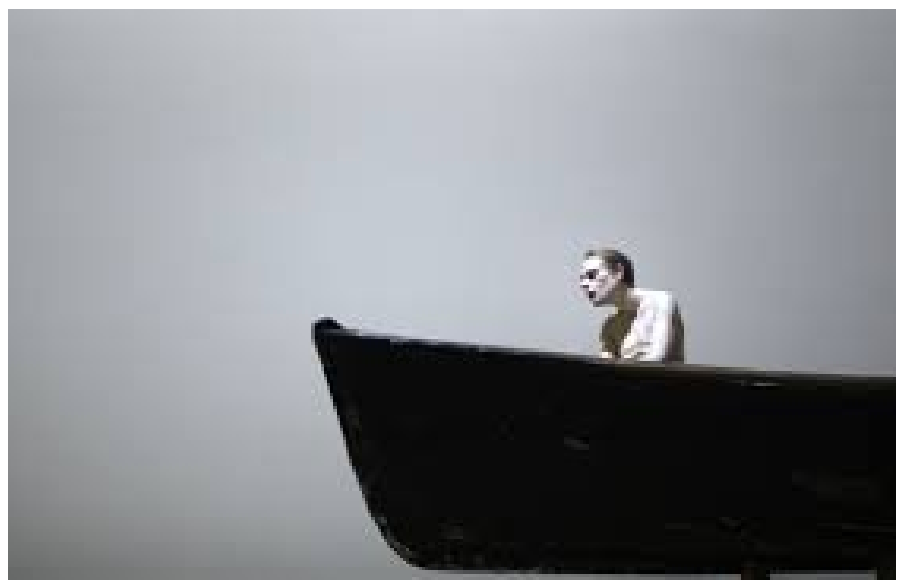

(MUEK, 2002)

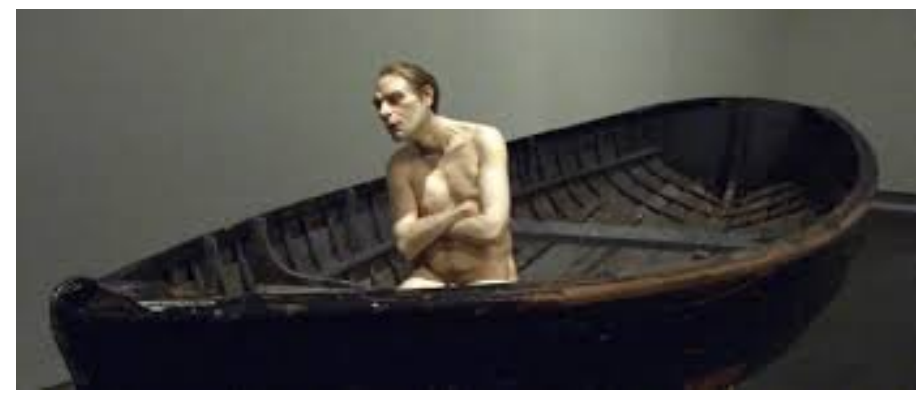

(MUEK, 2002) 
As esculturas de RON MUEK são de um realismo assustador. Tão interessante quanto apreciá-las é apreciar o olhar do público que, de fato, se vê nelas, nos mínimos detalhes. Isso até constrange, pois acaba-se, a partir da realidade das esculturas, rompendo-se o duplo do real construído por nós, especialmente quando entramos em exposições de arte.

Embora MUEK, por conta de um uso detalhado de materiais extremamente bem trabalhados, consiga fazer esculturas idênticas ao ser humano, ele as faz com tamanhos alterados. Isso possibilita ao público esculturas que provocam profundas identificações pelo detalhe, porém distanciamentos e quebras de sentido pelo tamanho.

Segue assim a escultura "Man in a Boat", o barco em tamanho real e o homem um pouco menor. O personagem possui o olhar ao longe, não olha para o público e nos passa uma profunda incerteza. O modelo dessa obra foi o pai do artista, impressionante como parece que MUEK entrou em contato com o conto roseano, ou transportou-se para imagem arquetípica do barco, do rio e do pai, indo-se, nu para um destino incerto.

Não há como modificarmos nosso destino, o barco está vazio, não há comida ou remos. É a condição trágica demonstrada, do ser humano e de sua impotência diante da própria vida. $\mathrm{O}$ que nos resta, às vezes, é observar e aguardar seu curso, seguir o que o rio oferece.

Não parece também ser à toa que os caminhantes eremitas costumam ser mais velhos e como o decurso da viagem em um barco traz internamente a condição de deixarmos de sermos crianças e nos tornarmos adultos.

Hoje entendo bem meu pai. Um homem precisa viajar. Por sua conta, não por meio de histórias, imagens, livros ou TV. Precisa viajar por si, com seus olhos e seus pés, para entender o que é seu para um dia plantar suas próprias árvores e dar-lhes valor [...] um homem precisa viajar para lugares que não conhece para quebrar essa arrogância que nos faz ver o mundo como imaginamos, e não simplesmente como é ou pode ser (KLINK, 2000, p.76). 


\subsection{A Vivência}

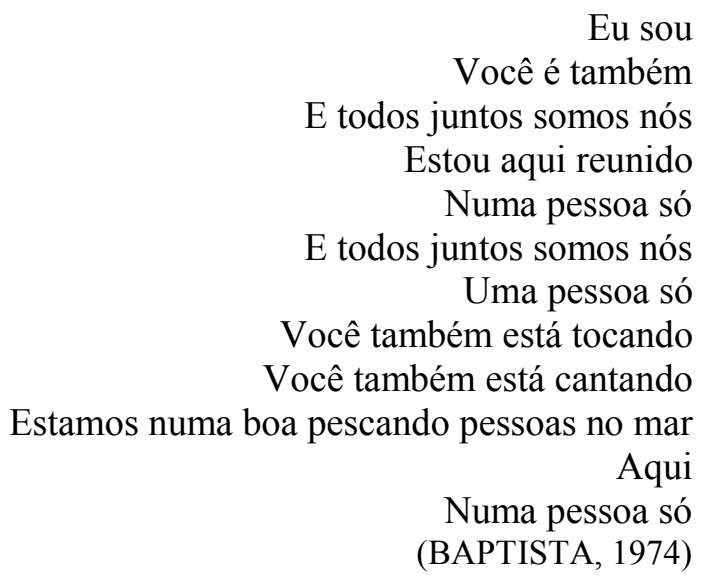

Em alguns momentos, quando nossa procura é intensa e verdadeira, encontramos o que não procurávamos. Nossa contínua busca pela veridicção do mundo esbarra, muitas vezes, na nossa coragem e exige uma disposição quase heroica de nos aventurarmos por nossas próprias contradições.

Até que ponto uma atitude cotidiana perante a vida, a si mesmo e ao outro torna-se elemento de atordoamento e reconstrução?

A grande questão talvez seja em como nos educarmos (conduzirmo-nos) ao outro. Para tanto, segue-nos a reflexão sobre o que é educar, quem somos nós e quem são os outros. $\mathrm{Na}$ percepção de tudo isso, articulam-se, entre si, todas essas partes: cada um está em tudo e tudo está em cada um.

Encontramos e desencontramos, representamos e interpretamos, vemos e "invejamos" essa veridicção nas nossas práticas e experiências, ora percebendo uma miragem de nossas essências pelos estereótipos, ora tocando sutilmente a fluidez de nosso "ir-se" na profundidade de nossos arquétipos.

A experiência é a rede pela qual contatamos o mar que somos nós mesmos e também que são os outros; o contato com o sentido a ser dado, a lúdica verdade intermitente que tanto nos incomoda, quanto desacomoda dos cômodos de nossas respectivas casas.

Trata-se a canção epigrafada de uma prática de "ser", "reunir", "tocar", "cantar", "pescar", em que se procura a vivência mais profunda de encontro com a ação, com o outro, consigo mesmo. 
A ambiguidade do "termo-característica" "nós" (substantivo ou pronome) da canção contamina a frase "somos uma pessoa só". Tanto pensemos aqui em solidão quanto em união: um padre pode dizer aos noivos "agora vocês são uma pessoa só" representando a união e solidariedade; da mesma forma, alguém pode dizer aos combatentes de guerra "vocês são uma pessoa só" referindo-se à solidão de cada soldado. Uma das possíveis formas de chegarmos a esse universo dialógico mais profundo é pelo olhar (em termos ontológicos), que nos contata com nosso objeto.

O olhar, dizíamos, envolve, apalpa, esposa as coisas visíveis. Como se estivesse com elas numa relação de harmonia preestabelecida, como se as soubesse antes de sabê-las, move-se à sua maneira em seu estilo sincopado e imperioso. No entanto, as vistas tomadas não são quaisquer, não olho um caos nas coisas, de sorte que não se pode dizer, enfim, se é ele ou se são elas quem comanda. (MERLEAU-PONTY, 1992, p. 130)

Essa identidade entre o olho e o objeto advém de um encontro, de uma tangência entre o mundo interno e o mundo externo. Essa solidariedade é causa de uma disposição do olho em não poder possuir o visível a não ser que seja possuído por ele. Sendo assim, o afastamento corporal entre o olho e o objeto deixa de ser afastamento propriamente dito e se torna ponte de encontro com o mundo. Por isso, na canção, diz-se: "Você também está cantando", nela, a canção como "objeto escutado" mostra ao ouvinte o quanto ele pode conduzi-la e exercê-la.

O educador só conduz quem consegue ver-se conduzido e ambos só se encontram quando tangenciam a ideia de "condução". A atividade do olhar do aluno foca o exemplo do olhar de seu condutor até se tornarem uma pessoa só.

Basta que eu veja alguma coisa, para saber ir até ela e atingi-la, mesmo se não sei como isso se faz na máquina nervosa. Meu corpo móvel conta no mundo visível, faz parte dele, e é por isto que eu posso dirigi-lo no visível. Por outro lado, também é verdade que a visão pende do movimento. Só se vê aquilo que se olha. Que seria a visão sem nenhum movimento dos olhos, e como o movimento destes não haveria de baralhar as coisas se, por sua vez, fosse reflexo ou cego, se não tivesse suas antenas, sua clarividência, se a visão não se precedesse nele? (MERLEAU-PONTY, 1992, p. 278) 
O grande enigma está em perceber que nossos movimentos não são somente apreensões de mundo, decisões de nosso espírito, fazeres absolutos, mas sim o amadurecimento de um olhar, olhar como um tecido nervoso que toca no objeto olhado, que se quase integra no objeto olhado. PESSANHA (1988) percebe essa dinâmica salientada por MERLEAU-PONTY quando o considera a distinção entre "imaginação reprodutora (formal)" e "imaginação criadora (material)" postulada por BACHELARD:

É preciso que ele seja belo para ver o belo. É preciso que a íris do olho tenha uma bela cor para que as belas cores entrem em sua pupila. Sem um olho azul, como ver realmente o céu azul? Sem um olho negro, como contemplar a noite? Reciprocamente, toda a beleza é ocelada. (BACHELARD, 2002, p. $31)$.

Há essa visão de encontro na canção epigrafada, uma das forças da imaginação de nossa mente (imaginação material), que escava o fundo de nós, procura o nosso "primitivo-eterno", prima pela "realização", pelo "fazimento" de nossas essências. O método "noturno" de BACHELARD nos convida a "errar" pela imaginação mais profunda, trazendo-nos novas visões; convida-nos a ter a coragem de entrarmos numa terra estrangeira, imigrantes; numa terra estrangeira de devaneios encontrada em "nós" mesmos.

Quando um sonhador de devaneios afastou todas as "preocupações" que atravancam a vida cotidiana, quando se apartou da inquietação que lhe advém da inquietação alheia, quando é realmente o "autor da sua solidão", quando, enfim, pode contemplar, sem contar as horas, um belo aspecto do universo, sente, esse sonhador, um ser que se abre nele. (BACHELARD, 2009, p.164)

E o sonhador de devaneios se permite "pescar pessoas no mar", "numa boa". A pesca é um tipo de experiência paciente e contemplativa, opondo-se à caça, à agricultura, à atividade industrial. Nela, achega-se na imensidão líquida com um fio (Ariadne) e, de fora, se imagina o que ocorre por baixo, a ação voraz do peixe que, ao ser predador, torna-se o objeto caçado.

MAR

Símbolo da dinâmica da vida. Tudo sai do mar e tudo retorna a ele: lugar dos nascimentos, das transformações e dos renascimentos. Águas em movimento, o mar simboliza um estado transitório entre as possibilidades ainda informes e as realidades configuradas, uma situação de ambivalência, que é a de incerteza, de dúvida, de indecisão, e que pode se concluir bem ou mal. Vem daí que o mar é ao mesmo tempo a imagem da vida e a imagem da morte. (CHEVALIER, 1993. p.592) 
O pescador penetra sutilmente no Mar e é também penetrado por ele quando recebe dele a constatação do movimento das ondas, da transitoriedade da vida pulsando em seus pensamentos. Ele e o Mar passam também a ser uma pessoa só:

Nós não temos um corpo. Nós somos um corpo, e é este corpo que sente, pensa e age e atua no mundo concreto que vivemos, carregando em si, numa memória corporal, a inscrição das memórias vividas e tudo o que elas significam. A facticidade no mundo (seu caráter concreto e resistente aos nossos desígnios) nos atesta esta rede de significações numa estrutura de "eksistência": nos movemos e percebemos o mundo num só ato orgânico e total, num só golpe, numa síntese corporal. (FERREIRA-SANTOS e ALMEIDA, 2012, p. 95)

Entendemos com o corpo a experiência no mundo numa complexa rede de significações e de trocas entre interno e externo, bem próximos do trajeto antropológico de GILBERT DURAND (1997, p. 41).

O indivíduo já possui uma constituição imagética inscrita em seu próprio corpo (reflexos dominantes). É do caminho entre a memória de seu corpo e a percepção mundo exterior que surgem os schèmes. Desses schèmes, advêm as imagens arquetípicas, nada mais nada menos que uma organização do instinto nos moldes de Jung. Essas imagens arquetípicas funcionam como um epicentro irradiador de um sistema simbólico, que tanto pode seguir um caminho de recriação de imagens pela mythopoiésis, quanto pela representação racional delas, aparelhagem ideológica conceitual. (GIRALDES, 2011, p.40).

O trajeto antropológico sugere uma ampliação das visões do processo de nossas absorções das experiências de vida. De uma forma mais sistêmica e complexa, nos moldes de EDGAR MORIN, ampliamos a forma de assistir ao ser humano, procurando senti-lo como um processo contínuo e dinâmico de configuração de existência.

Esse pensamento nos convida a preferirmos mais a integração e os sentidos criados para nossa existência à especialização e à técnica pedagógicas. Seria bem mais interessante uma pessoa, a partir de suas experiências de vida, dar um sentido a si própria e com isso criar ou escolher suas próprias técnicas de vivência a apropriar-se de técnicas já prontas, consideradas pelos seus inventores como salvadoras.

Se a pedagogia remete ao "como fazer", o imaginário remete ao sentido, à finalidade, porque é por meio dele que organizamos nossas experiências e atribuímos sentido à vida. Então, uma pedagogia do imaginário, independentemente do "como fazer", remeterá sempre ao sentido que se quer imprimir à educação e à vida. (TEIXEIRA, 2006, p.219) 
MANOEL DE BARROS escreveu um poema que ilustra bem essa proposta filosófica diante da vida, muito encontrada em alguns poetas:

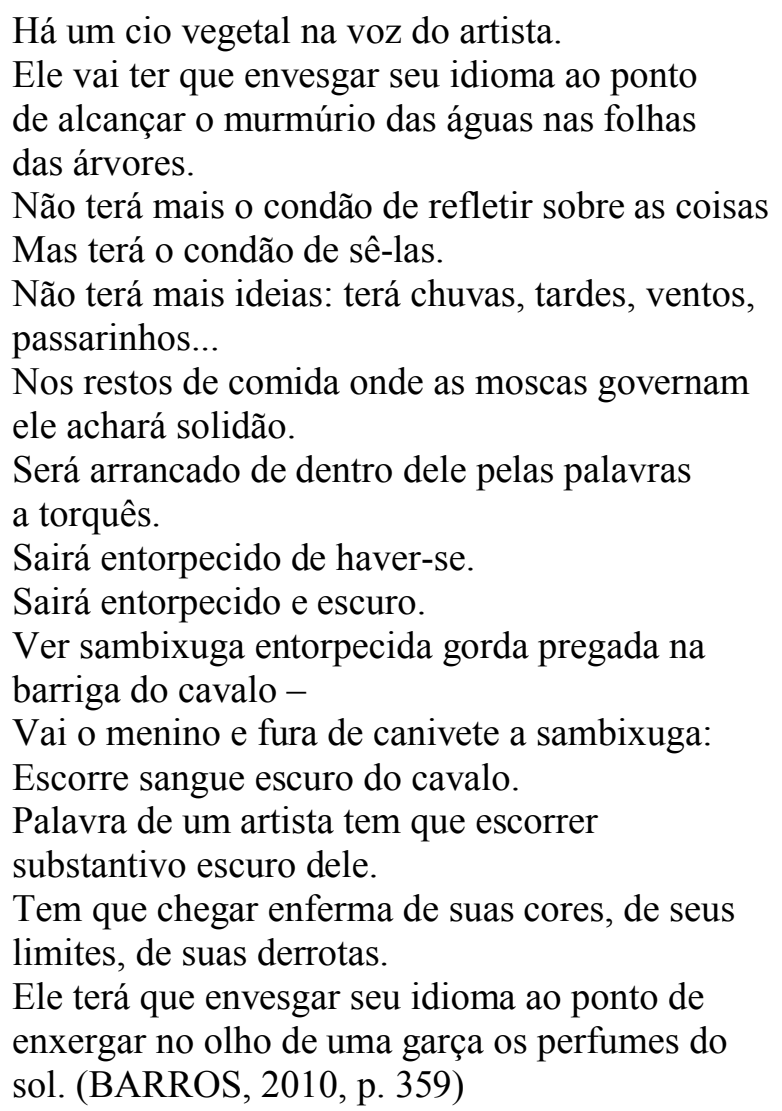

O autor sugere vermos a vida e a poesia de forma "envesgada". Desfocamos nosso olhar de nossa voz de nossos olhos, olhando-nos em nosso nariz a ponto de, ao nada vermos, vermos outro e outros a partir da desistência de olhar, e assim, tocarmos com nossos ouvidos também envesgados a face, ouvidos, olhos e pele das pessoas.

Pararemos de refletir metafisicamente sobre as coisas, pois um olho envesgado deixa de ser espelho-reflexo dos distanciamentos que temos do mundo, que não queremos tocar: pararemos de olhar com os olhos e passaremos a olhar com as mãos: quando os olhos "tocam no outro".

O governo do SEr e do haver-SE torcerá nossas palavras a ponto de nos arrancar de nós mesmos, furar nossos próprios olhos tal como Édipo no reencontro consigo e caminhar entorpecido de escuro, ensanguentado na pele/pelo/couro do cavalo escuro..

Aí, então, poderemos ver os perfumes do sol...nosso cio vegetal...

Caminharmos errantes pela estrada, pela terceira margem do rio... 


\title{
2.5. Lançamento de Âncoras e Vagabundagem Existencial
}

\author{
Talvez os imensos limites da pátria me lembrem os puros \\ e amarguem em meu coração as descrenças. \\ Sinto-me tão cansado de sofrer, tão cansado - algum dia, em alguma parte \\ hei de lançar também as âncoras das promessas \\ mas no meu coração intraqüilo não há senão fome e sede \\ de lembranças inexistentes. \\ (MORAES, 1998, p.255)
}

Dentre as várias possibilidades de encontro com o poema epigrafado, contemplamos alguém descrente, cansado de sofrer, saudoso de uma lembrança perdida, contudo, também um desejo potencializado de "lançamento de âncoras das promessas".

Essa antítese implícita de projeção/promessas (lançamento) e fixação (âncoras) à cata de uma pureza num lugar onde não há mais "nossa pátria" aproxima-se da concepção de homem e suas contradições a partir da metade do século XX.

Às instituições racionais que tiveram seu apogeu no final do século XIX, seguem-se as tribos pós-modernas que devem ser consideradas como a causa e o efeito de uma mutação, não sendo apenas um mero sonho para alguns "happy few" mas um sonho que se tornou real para a grande maioria. (MAFFESOLI, 2010, p. 30).

MAFFESOLI parte de uma lógica contraditatorial, ou seja, contínua tensão sem síntese para articular o par antimônico por que passa o homem hoje: sedentarismo (âncora) x nomadismo (lançamento).

A modernidade constituiu-se e estratificou-se pela ideia de progresso contínuo com base no trabalho e na produtividade. Para tanto, há uma fixação do "espaço" (perceptível na noção de "Estado", identidades nacionais) e do "tempo" (da História como implicação do presente e da Economia como projeção para o futuro, aplicações financeiras, dentre outros), ou seja, um sedentarismo (fechamento de conceitos) de espaço e de tempo alicerçado pela "racionalidade":

“A 'Racionalidade' - mas talvez fosse preciso abandonar esta palavra, pela razão que aparecerá no final desta frase - , que comanda a escritura assim ampliada e radicalizada, não é mais nascida de um 'logos' e inaugura a destruição, não a demolição mas a dessedimentação, a descontrução de todas as significações que brotam da significação do 'logos'. (DERRIDA, 1973, p. $13)$. 
A noção da metafísica da "verdade" baseada numa razão já distante de um "logos" inicial, ou seja, automatizada, fixa a linguagem técnica e científica a convenções que se ligam a outras convenções, reverberando-se no espaço e no tempo, estratificando-se, de certa forma, num sedentarismo racional e metafísico institucionalizado.

Esse sedentarismo estabelece uma territorialização individual através da fixação das identidades (homem/mulher; criança/adulto; profissão; país, pai/filho) e coletiva através das instituições (executivo, legislativo, judiciário, corporações, burocracias).

Por outro lado, a pós-modernidade tende a articular o par antimônico com um nomadismo existencial, uma errância de trabalho, de consumo; uma não fixação de profissão, identidade, família, sexo; uma busca da existência a partir de um enraizamento dinâmico ("Lançamentos de âncoras das promessas").

Um "enraizamento dinâmico" naquilo que ele sabe mobilizar a energia para viver aqui e agora. É um enraizamento desses, cujas expressões são inúmeras, que pode permitir que se fale de um real "reencantamento do mundo." (MAFFESOLI, 2010, p. 30).

A pós-modernidade numa perspectiva de união, de convivência do sagrado com o profano, da razão com a emoção:

Existe, no sentido simples do termo, uma concorrência entre os elementos arcaicos e o desenvolvimento tecnológico, no sentido mais etimológico o termo: cum-currere, eles "correm juntos". Eis a particularidade da pósmodernidade, aliar contrários. Fazê-los estar em sinergia, o que não deixa de dar à época sua originalidade. (MAFFESOLI, 1995, p. 148).

Justifica-se aqui um interessante campo de estudo tanto estético quanto cultural. Nele, caracterizaríamos a pós-modernidade, dentre outros valores, pelo "movimento". Mas não se trata, todavia, de um movimento reto e progressivo, objetivado e direcionado a alguma meta; trata-se de um movimento solto, despropositado, descomprometido com as instituições e o que a prática de um racionalismo lógico traz: uma espécie de movimento caótico/urobórico, como o de Ulisses retornando à Ítaca. Temos aqui o nomadismo, uma vagabundagem existencial, parente de um estado dionisíaco, opondo-se à tradição metafísica platônica.

Ei-la, a presente experiência deste trabalho, na sua nômade e vagabunda trajetória: encontramo-nos com o migrante no meio do caminho, escutamos suas histórias. Ele é capaz de observar e contemplar nos entremeios de nossa conversa essa movimentação de valores, nomadismo que guardamos dentro de nós mesmos. 
Sua importância para a pós-modernidade parece-nos apresentar-se em dois pontos. O primeiro na descaracterização da "moeda", entendida nos moldes de Diógenes: conta-se que o Oráculo

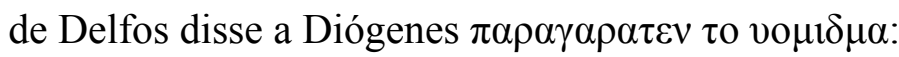

A palavra usual "nómisma" associa-se a dois significados: (1) indica a unidade monetária vigente, isto é, as "moedas", e (2) denota "costumes", "instituições", "valores aceitos" [...] assim, o significado exato do oráculo dado a Diógenes, conforme os relatos é "desfigurar a moeda vigente" (NAVIA, 2009, p. 42).

Diógenes tentou descaracterizar a moeda ou a efígie da moeda como diria FOUCAULT (2011) tal como um estrangeiro errante na sua pureza encontrada nos "imensos limites da pátria”. Diz-se que Diógenes perdeu a choupana em que vivia e decidiu viver em um tonel caminhando com uma lanterna à cata de um ser humano de verdade, não de uma instituição, de um nome, de um sexo, de uma profissão, de uma nacionalidade, de uma origem, de dinheiro, de casamento, de casa, de emprego, enfim, de qualquer valor que nos sedentarize.

O segundo momento da importância de Diógenes e, consequentemente, do migrante na pósmodernidade é a noção de parresia (dizer toda a verdade sem nenhum ornamento institucional que possa dissimulá-la) tão reforçada por FOUCAULT em seus últimos seminários:

A coragem cínica da verdade consiste em conseguir fazer condenar, rejeitar, desprezar, insultar pelas pessoas a própria manifestação do que elas admitem ou pretendem admitir no nível dos princípios. Trata-se de enfrentar a cólera delas dando a imagem do que, ao mesmo tempo, admitem a valorizam em pensamento e rejeitam e desprezam em sua própria vida. É isso o escândalo cínico. (FOUCAULT, 2011, p. 205).

A dor e a coragem de enfrentar essa dor é reforçada também por MAFFESOLI não somente para o migrante mas também par todos nós:

O próprio da mudança é ser dolorosa e essencialmente traumática. Socialmente, ela se exprime através de tensões graves, e destruições de toda a ordem a acompanham, é no vazio dessas destruições que se aninha a elaboração daquilo que está para nascer. (MAFFESOLI, 2010, p. 60).

Dessa forma, o estudo das experiências dos migrantes em seu aspecto simbólico e filosófico, será uma poderosa ferramenta para compreendermos mais um viés da pós-modernidade e de como ela reconstrói os procedimentos de vida de todos nós: 
O cínico é um funcionário da humanidade em geral, é um funcionário da universalidade ética. E esse homem - de quem se requer o desprendimento em relação a todos os vínculos particulares que poderiam ser os da família, da pátria, da responsabilidade cívica e política - só é libertado para poder cumprir a grande tarefa da universalidade ética, universalidade ética que não é a universalidade política de um grupo (a cidade ou o Estado ou até o gênero humano inteiro, mas a universalidade de todos os homens. (FOUCAULT, 2011, p. 266). 


\section{OBJETO}

O simbolismo na viagem, particularmente rico, resume-se, no entanto, na busca da verdade, da paz, da imortalidade, da procura e da descoberta de um centro espiritual (CHEVALIER et al, 1993, p.951).

Por mais que muitos de nós procuremos nos fixar numa terra com alicerces sólidos e profundos que vão desde a compra de um imóvel até a aceitação de uma nacionalidade; uma observação histórica mais longitudinal demonstra que não passamos de eternos migrantes e o que nos motiva é mais inconstante ainda, desde a fome e a guerra até, simplesmente, o tédio e a busca de novas emoções ou de nós mesmos. Em todas as situações, há a incerteza e o sonho de como será a nova terra e a nova vida atrelada ao grande vazio que nos toma diante do recomeço.

Grande parte das análises de fluxo migratório está diretamente relacionada a fatores de estrutura socioeconômica. Sabemos da importância deles, no entanto, nossa contribuição está em discutir no terreno das imagens, da representação arquetípica e de como tudo isso se entrelaça com os valores sociais, seara muito pouco trabalhada no universo acadêmico atual.

Um migrante recebe uma enxurrada simbólica, que começa na língua, perpassa pela alimentação e toma até o modo de pensar, no entanto, ele também influencia o meio, uma vez que nas relações humanas ninguém sai ileso e é capaz até de transformar a língua do país que o recebe, por exemplo.

Percebemos aqui o migrante como um ente que vivencia experiências humanas muito profundas, muitas vezes nos evocando condições relacionadas ao nosso modo de existir, de vivência de mundo, de configuração e reconfiguração de nossas vidas. Enfim, algo extremamente necessário, num momento em que todas as antigas identidades se esfacelam por entre a liquidez de BAUMAN e o multiculturalismo multifacetado de HALL, momento do homem não somente reconstituir sua identidade de nação e etnia, mas, principalmente, pensar nos reais motivos de ela existir, seu ethos.

Trataremos aqui de dois trabalhos densos e belos sobre o migrante tanto para ilustrarem nosso objeto de estudo quanto para permitirem, efetivamente, o "toque" no tema, ou seja, nossa migração para esta terra desconhecida, que é o migrante. 
O primeiro deles é a Tese de Doutorado de SILVEIRA JÚNIOR (2008), cujas imagens demonstram a migração como uma travessia a macular em nossa pele, nossa existência no mundo, fazendo-nos parte integrante dele pelas experiências mais profundas que ela traz. O segundo é o livro de OKUBARO (2006) que, diferente da latinidade no sangue de SILVEIRA JÚNIOR (2008), utiliza-se da disciplina e organização nipônicas para transparecer seu próprio cerne pela essência do pai, migrante japonês. Ambos os autores caminham e se encontram em pontos constantes por que passam muitos migrantes. Poderíamos iniciar tais encontros pelas supostas noções que temos de identidade:

"Quem eu de fato era naqueles dias de fome nos quais emagreci uns dez quilos? Um aventureiro, um romântico, um mentiroso, um mártir, um sudaca (termo empregado na Espanha para se referir aos imigrantes sulamericanos)? O que eu de fato seria? (SILVEIRA JÚNIOR, 2008, p.17)

Afinal de contas, perguntar "quem você é" só faz sentido se você acredita que possa ser outra coisa além de você mesmo; só se você tem uma escolha, e só se o que você escolhe depende de você; ou seja, só se você tem de fazer alguma coisa para que a escolha seja real e se sustente. (BAUMAN, 2005, p. 25)

A imprescindível pergunta, na maioria das vezes é verbalizada no passado ("Aí eu me perguntei: quem sou eu?"), pois, no momento imediato da migração, torna-se doída demais ou até não tenha surgido em nossa consciência, principalmente quando nos sentimos sem escolha, diante de tantas adversidades. Mesmo porque ela precisa ser proferida em uma língua e só a escolha da língua imbuída de tais reflexões já se torna difícil em meio à língua do espaço em que estamos a bombardear a língua da história que tivemos.

A nova língua se imiscui insidiosa no idioma natal. Uma nova sintaxe, um novo uso e ritmo. De repente a comunicação torna-se equívoca, estranhada, anuviada com os seus queridos distantes. Que talvez já não sejam mais tão "seus" e às vezes não tão "queridos". (SILVEIRA, JÚNIOR, 2008, p.18)

A mistura das estruturas da frase em japonês e em português gerava um idioma híbrido, que só seus filhos conseguiam entender com alguma precisão. Os meninos, por sua vez, desenvolveram uma grande capacidade para reproduzir essa maneira peculiar de Fussako falar. (OKUBARO, 2006, p. 381) 
A perda de referência linguística, por um lado, nos coloca num vazio estranho e traiçoeiro, em que, muitas vezes, sentimo-nos até enganados pelos nossos pensamentos, pelas significações das palavras para os outros e para nós; por outro lado, permite a reconstrução material sonora e simbólica de quem somos ao nos colocar nesse desconforto sonoro e conceitual, elementos já descritos aqui nos conceitos de transcriação (CAMPOS, 2013) e trajeto antropológico (DURAND, 1997).

Mas talvez, mais forte que a língua, está o encontro da casa na terra que não é nossa, pois a terra antiga já deixamos e a nova é algo emprestado pelos outros para fazermos com que seja nosso. ${ }^{4}$

O imigrante, já não podendo se atar a nada que seja seu, se apega ao provisório e fugaz. É comum encontrá-lo triste por sentir saudades da pensão ou da cidade que acaba de deixar. Mas, ao mesmo tempo, pode rejeitar cruelmente um conterrâneo recém-chegado. (SILVEIRA, JÚNIOR, 2008, p.18)

Uma área coberta nos fundos, eles transformaram em local para a lavagem de roupa e para o banho. A privada, um cubículo de madeira erguido sobre uma fossa, ficava uns dez metros atrás da casa. (OKUBARO, 2006, p.381)

Mesmo que o migrante viaje com bons recursos financeiros, haverá o profundo estranhamento com o espaço, com a casa. A penúria, a falta de identificação e a insalubridade são eufemizados com a ideia da transitoriedade, que se torna constante. Há, muitas vezes, uma recusa em se decorar uma casa passageira como ocorreu com Fussako em (OKUBARO, 2006).

Se, com um passo solitário, devaneando, numa casa que traz os grandes signos da profundidade, descemos pela estreita escada obscura que enrola seus altos degraus em torno do eixo de pedra, logo sentimos que descemos a um passado. Ora, para nós não há nenhum passado que nos dê o gosto de nosso passado, sem que logo se torne, em nós, um passado mais longínquo, mais incerto, esse passado enorme que já não tem data, que já não sabe as datas de nossa história. (BACHELARD, 2003, p.96)

\footnotetext{
${ }^{4}$ Posto que o caráter provisório do imigrante e de sua imigração não passa de uma ilusão coletivamente mantida, ele permite a todos que se sintam contentes com a habitação precária, degradada e degradante, que se atribui ao imigrante. Isso mostra até que ponto a dissimulação (i. e., a ilusão do provisório) que se encontra no próprio princípio da perpetuação da imigração é, aqui, necessária. E quando a imigração deixa, de fato, de ser provisória, enquanto a habitação continua sendo esta, é ainda a ilusão do provisório que permite mascarar o paradoxo de uma habitação para sempre provisória. (SAYAD, 1998, p. 78 apud SILVEIRA JÚNIOR, 2008, p. 28)
} 
Nosso espaço mais profundo, a busca da nova casa que seja também a casa de nossos sonhos, onde possamos ser o que queremos ou encontrar o que desejamos, perpassa também em nossa história mais longínqua: espaço e tempo se entrelaçam. Nossa memória, devaneando, procura nosso corpo, que toca no espaço também nos procurando em nossa memória. Encontramonos, dessa forma, no contínuo trânsito entre a casa perfeita do passado e a casa perfeita do futuro, permeando-nos tudo isso pelos espaços que chegam, sempre em parte, do que somos e do que desejamos ser.

Talvez seja bom guardarmos alguns sonhos para uma casa que habitaremos mais tarde, sempre mais tarde, tão tarde que não teremos tempo para construí-la. Uma casa que fosse "final", simétrica à casa "natal", prepararia pensamentos e não mais sonhos, pensamentos graves, pensamentos tristes. Mais vale viver no provisório que no definitivo. (BACHELARD, 2008, p.74)

Nossa proposta aqui é o encontro de pessoas, tempos, espaços, valores e sonhos. Mesmo que não sejamos migrantes propriamente ditos, somos migrantes impropriamente vistos, ou seja, trocamos também de casa, saímos das casas dos pais ou procuramos sair, casamo-nos, divorciamo-nos, predispomo-nos à hermenêutica da viagem no encontro conosco nessa eterna descida interna, que bem no fundo, é a casa de nossos pais, como se sentíssemos eternos Ulisses retornando etereamente à Ítaca sonhada ou a um paraíso perdido pelo tempo.

Mas a casa nova é vazia e sempre será vazia se, de fato, for nova. Deparamos com o vazio em nós e precisamos, muitas vezes, redescobrir características a partir do nada para nos descobrirmos; pois, se continuarmos com as mesmas características, é como se ainda não fôssemos nós mesmos, é como se ainda não tivéssemos, propriamente, escolhido algo em nossas vidas.

O migrante leva isso ao extremo. Por exemplo, Massateru, a personagem principal de $\mathbf{O}$ Súdito (OKUBARO, 2006) passou metade da vida sentindo-se um japonês em terra estrangeira aguardando o retorno ao Japão, o final da guerra, em que, com certeza, o Japão ganharia. Mesmo a guerra terminando, tanto Massateru como muito japoneses negam a derrota do Japão (aprenderam desde pequenos que o Japão nunca perde uma guerra) e lutam, bravamente, para, de certa forma, não saírem de casa, daquela casa longínqua de que vieram e que jamais poderiam trair. Até que, enfim, após muitas idas e vindas a aceitação do inevitável: 
Quando, afinal, decidiu aceitar o que até então lhe era inaceitável, suportar o insuportável, reconheceu, depois de tantas evidências que vinha se recusando a examinar, a derrota do Japão na guerra. Não era apenas a admissão daquilo que para todas as pessoas minimamente informadas era o óbvio. Sentia vergonha pelo engano que cometera, pelo desatino. (OKUBARO, 2006, p.347)

No entanto, como o bom japonês, tinha vergonha, mas não vergonha negativa. A vergonha transforma-se numa virtude diante da determinação que tivera quando defendera sua causa na Shindoo Renmei (organização que defendia a ideia de que o Japão ganhara a segunda guerra mundial). A vergonha, nesse sentido, virtuosa, purificava Massateru e fez com que ele constatasse, de uma vez por todas, que jamais retornaria ao Japão, que viveria no Brasil para sempre, que, finalmente, sua viagem e busca tinha acabado, ou melhor, reiniciado.

Massateru, então, fixa-se no Brasil ao permitir que seus filhos aprendam português, ao aceitar uma nova concepção filosófica de vida (Seicho-no-ie), ao orgulhar-se de seu filho servindo o exército brasileiro (CPOR). Houve aqui, em termos nietzschinianos uma aceitação positiva diante do trágico da vida e uma produção da significação de si mesmo atrelada às questões sociais pelas quais passou e ao local que ocupa na sociedade.

Massateru marcou sua história de vida em seus filhos. Um deles, Jorge Okubaro, escreveu tal história e passou adiante. Mesac Roberto Silveira Júnior também escreveu sua história entrelaçando-a com outros viajantes e passou adiante:

Uma educação que aprende no caminho, que aprende com os peregrinos, que aprende na peregrinação, se aproxima dessa educação transitória, em movimento, em ação, que insistimos em defender neste texto. Uma educação que aprende com o deslocamento humano. Com as pontes que representam esses deslocamentos. Quando os homens se traduzem em outros homens e o novo se instala no mundo. (SILVEIRA JÚNIOR, 2008, p. 98)

Devemos muito a mestres viajantes: Gandhi, São Francisco de Assis, Bashô. Mas talvez tenhamos aprendido muito mais com nossos pais ou avós, que viajaram pela experiência espacial do corpo a configurarem a experiência sonhadora da memória. 


\section{MÉTODO}

O homem não se revela em sua história, mas luta através dela.

(TAGORE, 1991, excerto 52)

A constrangedora pergunta: - Quem é você?, em sua estrutura lógico-discursiva, já possui significações abertas a serem resolvidas socialmente: os pronomes (quem e você), com seu vazio de significação, que será preenchido pela relação entre falantes, e o verbo ser na acepção de associação de conceitos a características.

Retomaremos tal pergunta, dessa vez, utilizando o tempo como referência.

Tal pergunta exige dos interlocutores uma composição interpretativa que vai desde a compreensão de mundo de quem perguntou até as compreensões que cada um possui de si mesmo, ou seja, se o contexto for uma festa de casamento, a resposta será: - Sou o pai do noivo! Caso seja uma olimpíada, a resposta será: - Sou um jogador de vôlei do Brasil! Se for diante da burocracia pública da imigração, provavelmente: - Sou fulano de tal!

Na prática, todas as respostas ligadas à identidade do ouvinte partem de cobranças sociais, todas são um esclarecimento de como seremos compreendidos pelos outros e, consequentemente, por nós mesmos. No entanto, algumas tendem a permitir a nossa escolha pessoal e outras não: o nosso nome completo, por exemplo, documentado pelos entremeios do Estado, não foi opção nossa e devemos reconhecê-lo como nosso durante a vida, significandonos nele ou aprendendo a transformar tal conjunto de sons como referenciador de nossa singularidade. Por outro lado, ser jogador de vôlei, na atual sociedade em que vivemos, possui uma centelha de escolha de nossa parte, uma opção, como se conseguíssemos ser alguma coisa além de nós mesmos, construída não somente pela herança dada pela sociedade a nós, mas também uma contribuição dada por nós para a sociedade.

Independente de podermos escolher ou não o que acontece conosco, há em nós um movimento de compreensão daquilo que aconteceu vinculado ao nosso passado, que nos posiciona, coloca-nos diante dos outros e de nós mesmos:

\footnotetext{
"A compreensão do passado" une o passado ao presente, de um modo que nos prepara para o confronto com o futuro. Desta forma, isto serve como taquigrafia para "consciência histórica". Ao mesmo tempo, sua conexão com a ação é aparente, pois a visão sobre o passado a partir do presente nos prepara para a ação (se a ação for resolver "coisa alguma" ou não). (SEIXAS, 2012, p.538)
} 
As noções apresentadas atrás, embora um pouco direcionadas para a produção didática da aprendizagem de História na escola, podem ser também refletidas nas compreensões que os indivíduos possuem de si mesmos. São essas compreensões, interpretações que temos, no presente, de coisas que fizemos ou que fizeram conosco; são elas que nos dão uma ideia do que é o presente para nós, que nos posicionam diante da vida e do mundo e que nos encaminham para um futuro, promissor ou não:

Eufemismo, os felizes tempos, eufemismo apenas, igual aos outros que nos alimentam, a saudade dos dias que correram como melhores. Bem considerando, a atualidade é a mesma em todas as datas. Feita a compensação dos desejos que variam, das aspirações que se transformam, alentadas perpetuamente do mesmo ardor, sobre a mesma base fantástica de esperanças, a atualidade é uma. Sob a coloração cambiante das horas, um pouco de ouro mais pela manhã, um pouco mais de púrpura ao crepúsculo a paisagem é a mesma de cada lado beirando a estrada da vida (POMPEIA, 1996, p.1)

Ao chamar "eufemismo" os "felizes tempos passados", ao considerar a "saudade" como "um eufemismo" de dias que "não eram melhores", o autor sugere uma desilusão, uma descrença diante de uma vida que, anteriormente, creditava-se feliz, ou seja, a composição histórica que o indivíduo, já mais velho, possui de sua própria vida é de que, em alguns momentos, ele esteve, embora, ilusoriamente, feliz. Notamos aqui como o presente atual refez concepções que esse indivíduo possuía de si mesmo e como o "olhar para trás de nossas vidas" as reconstitui segundo a segundo:

O tempo acaba o ano, o mês e a hora,

A força, a arte, a manha, a fortaleza;

O tempo acaba a fama e a riqueza,

O tempo o mesmo tempo de si chora;

O tempo busca e acaba o onde mora

Qualquer ingratidão, qualquer dureza,

Mas não pode acabar minha tristeza,

Enquanto não quiserdes vós, Senhora.

O tempo o claro dia torna escuro

E o mais ledo prazer em choro triste;

O tempo, a tempestade em grã bonança;

Mas de abrandar o tempo estou seguro

O peito de diamante, onde consiste

A pena e o prazer desta esperança.

(CAMÕES, 2013) 
A noção dada a nós por Camões de que o tempo, em longo prazo, demonstra o quanto a solidez aparentemente perpétua é efêmera, potencializa-se quando refletimos que muito dessa efemeridade é configurada por nós mesmos e não somos somente vítimas, mas elementos agentes de tal efemeridade, uma vez que a mudança de nosso olhar diante do acúmulo de experiências modifica nossas experiências:

A consciência histórica está fundada nessa ambivalência antropológica: o homem só pode viver no mundo, isto é, só consegue relacionar-se com a natureza, com os demais homens e consigo mesmo se não tomar o mundo e a si mesmo como dados puros, mas sim interpretá-los em função das intenções de sua ação e paixão, em que se representa algo que não são. (RÜNSEN, 2001, p.57)

De certa forma, a "consciência histórica" encontra-se na descoberta de que a temporalidade e o passado são também construídos por nossas ações e paixões do presente, presente esse, que tanto é constituído como produto de compreensão do passado quanto do momento sociocultural por que experimentamos.

Se a demanda dos dias de hoje, por exemplo, é a imposição ou compreensão do sistema capitalista-burguês e sua gestão; ao olharmos o passado, escolheremos as gestões e o comércio no sentido lato como elementos da constituição das verdades a serem descobertas e de como elas fazem com que se sejamos como somos. Os demais documentos ou histórias contadas, que não sejam vinculados a isso, sequer serão percebidos, ou, quando percebidos, serão colocados em segundo plano, pois nosso olhar compreensivo não alcança aquilo que não vemos como elemento constitutivo do que somos atualmente.

O discurso tem de levar em conta sua atualidade para, [primeiro], encontrar nela seu lugar próprio; segundo, dizer o sentido dela; terceiro, designar e especificar o modo de ação, o modo de efetuação que ele realiza no interior dessa atualidade. Qual é a minha atualidade? Qual é o sentido dessa atualidade? E o que faz que eu fale dessa atualidade. (FOUCAULT, 2010, p.15)

A flexibilidade despertada em nossos olhares ao observarmos o passado reflete, dessa forma, na flexibilidade ao assistirmos nosso presente: tal qual os antigos filmes de ficção científica, em que alguém ia ao passado para flagelar o assassino do pai e fazer com que o pai renasça, nós nos assustamos com vários "presentes" a serem descobertos em possíveis novas concepções. 
Compreensão do passado é mais que o passado, porque nós sabemos como as coisas aconteceram: na hora de comer, eu não sabia que eu iria ficar doente, e agora, revendo, eu sei. Mas compreensão do passado é também menos que o passado, porque é seletiva. (SEIXAS, 2012, p.539)

O fato de uma doença surgir, por exemplo, foca meu olhar em determinadas ações no lugar de outras na hora de conceber meu passado e meu presente. Caso eu me cure da doença e passe por alguma questão ligada a relacionamentos familiares, meu foco será outro e assim por diante.

Dessa forma, a riqueza de um relato em uma narrativa oral de história de vida está tanto na ambivalência do duplo acarretamento entre passado e presente quanto na ambivalência do duplo acarretamento entre a compreensão do passado individual e a compreensão do passado coletivo.

O relato em si traz que o narrador considera importante em sua trajetória dando uma idéia do que foi sua vida e do que ele mesmo é nesse momento. Essa atitude reflexiva permite a re-experimentação de situações passadas não apenas do ponto de vista do desenrolar dos fatos, mas pela re-significação de episódios marcantes para o narrador, que se permite inverter (ou subverter) a narrativa obedecendo a uma cronologia própria da afetividade implicada no evento ocorrido, dando ao seu texto um contexto. (RUBIO, 2006, p.24)

É o relato narrativo, portanto, fonte de reconhecimento entre nosso presente e nosso passado como também entre nós e os outros, ou seja, o que poderíamos chamar, em nossos termos, como identidade: "Nessas histórias nos reinventamos, possibilitamos a nós um encontro em que experienciamos nossas verdades em um entrecruzamento de paisagens, ajuste de paixões e, principalmente, reconhecimento do outro em nós mesmos". (GIRALDES, 2011 p.25)

O contínuo entrelaçamento da temporalidade, das reinterpretações e das reinvenções, que podemos perceber durante a História que se faz dos Historiadores (Historiografia), é percebido também nas histórias individuais, como se, quase de modo teatral, passássemos pelo momento do reconhecimento singular, vívido, em que tudo se atualiza e se organiza no ponto da elaboração da narrativa, no entanto, aquilo só significa quando reverbera em algo parecido ocorrido no passado:

Ainda que o tempo seja quase sempre visto como um elemento linear, onde ao nascer o sujeito traça uma linha e por ela segue até chegar à morte numa perspectiva de continuum, tem-se também a concepção daquele tempo que parece nunca se esgotar, transformando-se na medida em que se reveste de significado. (RUBIO, 2006, p.26) 
A História linear, disciplinada pelo estatuto de ciência moderno, opõe-se ao relato de história de vida individual que, com sua contínua reinvenção, aproxima-se da ideia de símbolo esboçada por GILBERT DURAND:

É através do poder de repetição que o símbolo preenche indefinidamente a sua inadequação fundamental. Mas esta repetição não é tautológica: é aperfeiçoante através da acumulação de aproximações. É comparável nisso a uma espiral, ou melhor, a uma solenóide, que em cada volta define cada vez mais o seu objectivo, o seu centro. (DURAND, 1993, p. 13)

MIRCEA ELIADE aproxima-se desse pensamento quando analisa ontologia arcaica, ou seja, o que é o "ser" e a "realidade", partindo do comportamento do homem nas sociedades prémodernas:

O passado nada mais é do que uma prefiguração do futuro. Nenhum acontecimento é irreversível, e nenhuma transformação é final. Num certo sentido, é até possível dizer que nada de novo acontece no mundo, pois tudo não passa de uma repetição dos mesmos arquétipos primordiais; esta repetição, ao atualizar o momento mítico em que o gesto arquetípico foi revelado, mantém constantemente o mundo no mesmo instante inaugural do princípio. O tempo só torna possível o aparecimento e a existência das coisas. Não exerce uma influência final sobre sua existência, já que, ele próprio, passa por uma constante regeneração (ELIADE, 1992, p.80).

Para o Homem das sociedades arcaicas, as coisas se repetem de modo infinito, sendo essa repetição o movimento que configura a realidade aos acontecimentos, ou seja, há a repetição dos fatos porque relembram sempre um exemplo arquetípico inicial.

A discussão da compreensão do passado e da consciência histórica levantada por RÜNSEN e SEIXAS, somada às discussões sobre relatos narrativos nas concepções de histórias de vida de indivíduos (por RUBIO e GIRALDES), bem como à abordagem do pensamento simbólico arcaico de DURAND e ELIADE, impulsiona-nos a considerar que, ao imaginarmos o caráter cíclico da narrativa de vida de uma pessoa, percebemos que o elemento construtor da narrativa advém da força identitária que o indivíduo possui. A identidade, dessa forma, será entendida como ordenação da nossa compreensão do passado e de nossa consciência histórica, que, embora inicialmente parta de uma acepção individual, une-se também à coletividade. 
A força da constituição de nossa identidade torna-a flexível, possibilita o trânsito entre estereótipos e arquétipos, construindo o nosso presente e reconstruindo o nosso passado. Por exemplo, ao se fazer a pergunta: - Quem é você?, obtendo-se a resposta: - Sou um jogador de vôlei do Brasil! dependendo-se da interpretação do sujeito que respondeu, pode-se construir tanto um passado no qual o indivíduo lutou bravamente e enfrentou diversidades para ser tal jogador, quanto, simplesmente, por comodidade, nada fez e, ao nada fazer, tornouse tal jogador, levado pela vida. Por incrível que pareça, essas duas histórias podem ser contadas pelo mesmo sujeito, dependendo do momento que ele passa em sua vida e de como ele vê suas experiências. O tempo, a história contada pelo sujeito possibilita um aparecimento de uma experiência que se modifica a cada recontação de história.

Édipo Rei (SÓFOCLES, 1990) é um exemplo primoroso de como a descoberta do passado reinventa o presente e articula continuamente a noção de tempo à constituição da liberdade de escolha do indivíduo, opondo-se à prescrição advinda do destino (que pode ser entendida, nos dias de hoje, como influenciado pela sociedade e pela cultura):

Os acontecimentos principais da peça, na realidade, nem fazem parte da profecia: Apolo não vaticinou a revelação da verdade, o suicídio de Jocasta ou a cegueira auto-inflingida de Édipo. O "destino" não desempenha nenhuma função nas ações de Édipo na peça. (KNOX, s.d., p.3)

O destino construiu o contexto da peça Édipo Rei, contudo, não protagonizou nada da peça em si, do momento de construção (ou reconstrução) que Édipo faz de si mesmo, da verificação das ações que ele fez e que ele faz por vontade própria, da eterna pergunta que nos cerca na vida: - Até que ponto somos o que queremos ou somos o que os outros querem que sejamos ou o que foi destinado a sermos?

A questão linear e determinista do tempo encontra-se no pensamento ocidental, no que entendemos pela origem da racionalidade advinda de determinados filósofos pré-socráticos. Para conseguirmos atingir nossa criatividade, nosso universo simbólico, outras identidades nossas; precisamos, de certa forma, subverter a linearidade de nossa história. Talvez o ethos de nossa identidade seja nosso daimon. 
Não é fácil definir o sentido exato de daimon nessas tragédias. Se, por um lado, a palavra significa "divino", por outro, parece sugerir algo como "marca individual", particularmente depois de Heráclito - com cujo pensamento Sófocles tem tantas relações - ter escrito em seu conhecido aforismo: ethos anthropo daimon, "caráter é para o homem daimon". Kirkwood associa daimon à moira ("fado") e à tyque ("acaso"), registrando a ocorrência de "uma qualidade pessoal no sentido de daimon; ela é concebida como uma força ativa, condutora. (VIEIRA, s.d.,p.28)

A construção de nossa identidade, dessa forma, passa pelas nossas escolhas por um lugar em nosso passado, lugar esse diretamente vinculado à concepção de presente construída por esse mesmo passado, pelo momento sociocultural, pela nossa posição na sociedade e por nossas idiossincrasias e singularidades.

Utilizar o relato de história de vida como método da percepção da identidade do indivíduo, direcionando-se o viés analítico para a flexibilidade das concepções entre passado/presente, indivíduo/coletividade depreende, para nós, um caminho interpretativo em que, ao permitirmos essa flexibilidade, poderemos perceber o que as rigorosas estruturas de conhecimento já prontas não percebem exatamente por conta de sua rigidez.

Trata-se de procurar uma produção de conhecimento que reconheça nossos limites na percepção sociocultural e histórica e que possa, junto a outras formas de produção de conhecimento, democratizar e pluralizar o que entendemos por produção científica.

KATIA RUBIO não apenas sistematizou a História de vida como método investigativo, criando grupos de estudos acadêmicos que o abordassem, como também fez dela elemento norteador de 15 anos de vida acadêmica.

Em O Atleta e o mito do herói (RUBIO, 2001), a História de vida integrou-se com o percurso do Herói de CAMPBELL (2009). Seguiram-se, então, as demais pesquisas, nas quais o trabalho centralizou-se tanto no sujeito em si quando na sua história. Daí depreendemos Medalhistas olímpicos brasileiros: histórias e imaginário. (RUBIO, 2006).

Com isso, a visão focou-se do esporte pela ótica do atleta, das mulheres atletas (RUBIO, 2011) e, posteriormente, construiu-se um trabalho extremamente marcante não somente para o percurso do método Histórias de vida mas também para uma cartografia do esporte olímpico brasileiro: Atletas olímpicos brasileiros (RUBIO, 2015):

Por meio dessas narrativas, é possível se ter um panorama ampliado das questões mobilizadoras daquilo que é o esporte brasileiro na atualidade e que interfere diretamente na sua organização e na construção de políticas públicas para o seu desenvolvimento. (RUBIO, 2015, p.19) 
Aos poucos, as Histórias de Vida penetram no meio acadêmico e enriquecem nosso repertório de análise já tão cheio de estatísticas, reportagens e análises sociológicas. "A boa e velha conversa, despretensiosa, desvinculada de todo o aparato tecnicista que nos encarcera, permite o recomeço, o reinício e nos envolve em nossos princípios, tornando-se uma visão de mundo não apenas de um, mas de todos" (GIRALDES, 2011, p.25).

Nosso estímulo inicial será pedir ao nosso entrevistado que conte sobre a história da vida dele da forma que ele achar melhor. Advêm, então, lembranças familiares, sua vida profissional, viagens, curiosidades... As entrevistas foram gravadas em áudio e, posteriormente, transcritas. Quanto à transcrição, vale lembrar que ela é uma recriação da história contada pelo entrevistado, MEIHY utiliza o conceito de transcriação para definir melhor o processo hermenêutico pelo qual passaram as entrevistas:

O conceito de transcriação é uma mutação, "ação transformada, ação recriada" de uma coisa em outra, de algo que, sendo de um estado da natureza, se torna outro. A beleza da palavra composta por "trans" e "criação" sugere uma sabedoria que ativa o sentido íntimo do ato de transcriar. Fala-se de geração, mas não de cópia ou reprodução. Nem de paródia ou imitação. [...] Nesse sentido, aplica-se à prática da transformação do oral no escrito; a metáfora da água que transmuta do líquido para o gasoso. (MEIHY, 2007, P.133)

O conceito de transcriação de MEIHY tratado do método da entrevista aproxima-se bastante do conceito de transcriação de HAROLDO DE CAMPOS revisto nas nossas referências iniciais neste trabalho. Transcriamos, então, a história falada em uma história escrita. Procuramos descrever quaisquer alterações pertinentes do entrevistado no momento em que fala (impostação de voz, silabação, dentre outros), bem como ilustrar a entrevista com informações ditas antes e depois do gravador ligado, momentos em "off”, que, às vezes, podem trazer informações importantes à história contada, respeitando sempre o anonimato do entrevistado, ou seja, omitindo dados que possam revelar sua identidade.

Dessa forma, pediremos ao "sujeito/objeto" de nossa pesquisa que relate a história de vida dele de forma livre e descompromissada. A forma com a qual ele escolhe o que dizer e como dizer nos interessa no sentido de perceber como ele constrói a própria vida e identidade de si mesmo, sua relação com o outro e a interligação que ele faz entre presente e passado. $\mathrm{O}$ entrevistado será informado das intenções da pesquisa e assinará o TERMO DE CONSENTIMENTO LIVRE E ESCLARECIDO (ANEXO B). 


\section{HISTÓRIAS}

\subsection{Resumo da Primeira História}

Nosso primeiro entrevistado possui 75 anos e nasceu em um vilarejo na Croácia. Ao ser chamado para servir a marinha da Iugoslávia, quando tinha 19 anos, em 1959, fugiu da fronteira com mais dois amigos. Ficou refugiado na Itália por um ano e meio até aceitar a viagem para o Brasil. Desembarcou no Rio de Janeiro e depois viajou para São Paulo, onde se estabeleceu.

Trabalhou em São Paulo como sapateiro (profissão aprendida em colégio técnico na Croácia), trabalhou também em restaurante e em cobranças numa fábrica de tintas em São Bernardo do Campo, casou-se no Brasil com uma migrante Croata e teve 3 filhos. Dois dos seus filhos estabeleceram-se no Brasil, já a filha retornou à Croácia, onde vive há 23 anos.

Das escolhas que poderia ter feito na narrativa da história de sua vida, optou por detalhar bastante os percursos, cidades, marcas da longa viagem: Koper, Trieste, Zagreb, Cremona, Lombardia (próxima a Milão), Nápoli, Rio de Janeiro e São Paulo.

Fez questão também de dizer que conhece a cidade de São Paulo inteira, que saberia falar para mim onde fica qualquer lugar de São Paulo, grande façanha diante do tamanho da cidade. Todo esse conhecimento conseguiu quando trabalhava com cobranças e viajava, por dia, 200 quilômetros.

Esse caráter quase peregrino segue até hoje. Hoje trabalha numa agência de viagens de um de seus filhos, como se a identidade fosse constituída, mais que no trânsito Brasil-Croácia, no trânsito da vida e das demais viagens que fez ou que ajuda os outros a fazerem. Um de seus filhos mantém esse caráter viajante ao gerenciar uma agência de viagens enquanto o outro, numa viagem de retorno à Croácia, reestruturou sua vida ao modificar de profíssão, da Engenharia para as Letras. 


\subsection{Comentários à Primeira História}

As nações todas são mysterios. Cada uma é todo o mundo a sós. Ó mãe de reis e avó de imperios, Vela por nós!

Teu seio augusto amamentou Com bruta e natural certeza O que, imprevisto, Deus fadou. Por elle resa!

Dê tua prece outro destino A quem fadou o instincto teu! $\mathrm{O}$ homem que foi o teu menino Envelheceu.

Mas todo vivo é eterno infante Onde estás e não ha o dia. No antigo seio, vigilante, De novo o cria! (PESSOA, 2010 p.22)

O prenúncio identitário de um Croata, em 1959, talvez estivesse em, efetivamente, sair da própria Croácia. Ela por si, como país instituído, não existia diante do regime comunista Iugoslavo, no entanto, os Croatas a mantinham pela tradição familiar, pela religião Cristã Católica Apostólica Romana e pela escrita da língua em alfabeto latino.

Há uma grande mistura étnica na região, no entanto, grosso modo, para fins didáticos, poderíamos separá-la entre Croatas, Sérvios (Cristãos Ortodoxos, que falam a mesma língua, mas a escrevem em alfabeto Cirílico) e Bósnios (Muçulmanos, que também possuem língua bem próxima, mas tendem a escrever em alfabeto árabe).

Todo esse cadinho cultural formata-se diante de um sistema burocrático marxista ateu, cuja ideologia se projeta sobre todas essas identidades, um pouco impondo-lhes o regime, um pouco fazendo "vista grossa" e permitindo fugas, uma vez que a emigração pode ser interessante para um país em crise, com carência de empregos e instabilidade econômica.

Sendo assim, nosso entrevistado tornou-se mais Croata ao fazer passeatas aqui no Brasil a favor da Croácia, ou seja, parece que a viagem lhe fez o reencontro com os pais (país) interno com sua casa onírica em eterna construção. 
A consciência de estar em paz em seu canto propaga, por assim dizer, uma imobilidade. A imobilidade irradia-se. Um quarto imaginário se constrói ao redor do nosso corpo, que acreditamos estar bem escondido quando nos refugiamos num canto. As sombras logo se tornam paredes, um móvel é uma barreira, uma tapeçaria é um teto. Mas todas essas imagens imaginam demais. E é preciso designar o espaço da imobilidade fazendo dele o espaço do ser. (BACHELARD, 2008, p.146)

É como se todos nós procurássemos um lugar em que poderíamos "descansar em paz" com o eterno desejo ambíguo de não encontrá-lo definitivamente e chegarmos ao "fim angustiante". O Brasil traria essa pretensa imagem de imobilidade a ser constituída, um país tranquilo, um lugar em que se conseguiria um emprego, casa. O Brasil era um país onde se poderia escrever em alfabeto latino, ser Cristão e levantar a bandeira da Croácia em praça pública, um lugar onde os exércitos pareciam distantes e não lhe impunham lutar por uma pátria que não era sua.

ENTREVISTADO - É !!!! Ninguém mexia comigo eu lá sentado no Rio de Janeiro, Rio era uma beleza ... a cidade mais bonita do mundo, eu, como criança, sonhava ver Rio de Janeiro, o Brasil jogou 1950 com o Uruguai, perdeu, eu tinha 12 doze anos, eu recebi jornal, nunca ia imaginar ver um dia Rio de Janeiro, depois de 9 anos eu ia pra cá, no Brasil fala assim, 250 mil pessoas chorando que perdeu eu tava lendo no vilarejo onde eu nasci.

Ele reencontrou o vilarejo onde nasceu no Brasil, ninguém mexia com ele, a noção de liberdade encontrava-se diretamente com a ideia de não ser incomodado e foi justamente o fato de ser incomodado pelo governo iugoslavo que o tirou de lá. Talvez possamos encontrar implícita a imagem antiga que o europeu possuía sobre a América como sendo o Paraíso perdido da religião cristã o reencontro com algo sagrado e consigo mesmo.

O paraíso

fez em Portugal a febre de navegar

fez o índio migrar do litoral para o poente

fez o imigrante largar da Europa e do Oriente

Quimera a que não se pode renunciar

o paraíso acaso será?

(MILAN, 2014) 
O poema acima se encontra na estação paraíso do metrô de São Paulo. Possivelmente nosso entrevistado passou várias vezes por lá. Tal poema faz parte de uma bela instalação. Nela, ao descermos a escada fixa numa das suas entradas, quando elevarmos nossa cabeça, vemos num teto azul letras de chapa galvanizada pintadas de dourado e podemos ler esse poema tanto parados na escada quanto descendo por ela.

Para mim, torna-se até mais interessante sua leitura descendo a escada quando, a partir de nosso movimento, assistimos ao movimento das letras e refletimos um pouco sobre quantas pessoas vieram para cá e sobre a multiplicidade que temos dos paraísos possíveis, perdidos ou reconquistáveis pela nossa contínua esperança de procurarmos saber quem somos através de nossa busca ao nosso espaço no mundo.

A língua também faz parte dessa busca. Quanto à língua e à adaptação à língua portuguesa, o entrevistado nos disse que não houve grandes problemas devido ao tempo que passou na Itália e à proximidade do italiano com o português. No entanto, cabe-nos observar fortes marcas de vocabulário e estrutura discursiva que se mantêm como marcas das viagens que fez e de sua origem.

Dentre elas, a pronúncia diferente dos sons nasais ("migraçon"), a diferença na colocação e escolha das preposições (“eu veio no Brasil”), a diferença na utilização dos tempos verbais (“eu veio da Itália”), a diferença nos gêneros gramaticais (“escreve em cirílica”).

O próprio falar do entrevistado, dessa forma, demonstra a busca da integração e do hibridismo cultural. Seus filhos, como ele, falam croata e português e pelo seu falar nota-se como a mistura de línguas tende a inventar novidades tanto fonológicas quanto semânticas.

Tal como Hermes brincalhão, ou o Exu iorubá, deuses da ambiguidade, dos viajantes e da possibilidade de conciliação entre universos diferentes; não se percebe incômodo algum por parte do entrevistado em relação a essas diferenças. Dentro da praticidade da vida advinda de um contínuo viajante e de um profissional técnico, preocupações com a linguagem e pronúncias da língua são tarefa de algum filho que acha importância nisso e que ele, simplesmente ri e se diverte. Ele se diverte com a própria juventude ao percebê-la como parte do passado diante da idade de hoje:

É !!!! Eu era jovem queria procurar vidas melhores, oportunidades melhores, saí que todos os jovens hoje quer sair, acha sempre no outro lugar é melhor que onde nasceu, comunismo, perseguições e essas coisas... 
Todos os obstáculos à viagem: a distância da família e do vilarejo em que nascera, a ida ao um país desconhecido de língua diferente, os iminentes perigos, a possibilidade de ser preso na fronteira ou de não ser recebido nos países de destino, eram simplesmente enfrentados com a máxima: "Eu era jovem, as coisas são assim, qualquer um no meu lugar faria o mesmo".

Por que não admitir que existe, no inconsciente coletivo, uma real necessidade de aventura? O que nos obriga a abrir os olhos para a figura nômade que, de fato, está em ação na vida social e que se pode encontrar, por exemplo, em todos esses jovens que, atualmente, deixam seu país para viver uma aventura existencial e profissional. (MAFFESOLI, 2010, p.51)

Para alguém que espera um épico hollywoodiano, uma sequência de sofrimentos e superações que valorizem uma saga de migrante tal como relatou OKUBARO (2006), enfim, para quem espera uma pessoa mais velha que diga o quanto sua vida foi valorosa pelo sacrifício desmesurado, encontra-se alguém que simplesmente diz: "Eu fiz porque as coisas são assim e qualquer um no meu lugar também o faria”.

Tal procedimento poderia até ser psicologicamente interpretado como uma negação ao sofrimento tendo como subterfúgio a distância temporal. Mas não nos cabe aqui fazer esse tipo de análise, que se tornaria até leviano, uma vez que não conhecemos o suficiente da vida do entrevistado e não nos utilizamos neste trabalho de nenhum referencial teórico que possa abarcar a hipótese.

O que nos interessa, num cunho antropológico, é o mecanismo existencial utilizado pelo entrevistado para reconstruir o seu próprio passado. Ele aproxima o "espírito jovem" ao "espírito trágico" quando coloca como causa central para sua viagem: "Eu era jovem". Parece o jovem parece ser aquele destituído de convenções ou significações prontas e, justamente por isso, capaz de traçar caminhos novos e permanecer viajante.

A partir daí, podemos aprender através de um migrante que a migração pode ser algo extremamente normal e esperado, que não há nada de especial nisso como também talvez não haja sentido nem na própria entrevista. Isso tudo se reforça ao ser perguntado se ele não sentiu medo em algum momento da migração que fez:

ENTREVISTADO - Não, eu fugi da fronteira, chama Koper, atual Eslovênia, Eslovênia, fronteira de Trieste a Trieste de Koper .... saí de capital da Croácia que é Zagreb, que é onde fez o curso de escola técnica eu fiz lá de sapateiro, lá é profissional, tudo profissional tem que. 
No momento presente, tudo parece ter sido fácil demais. A ausência do medo é elaborada pelo entrevistado, mais uma vez, pela trajetória e suas marcas (lugares em que passou) e pela profissão aprendida. De um lado temos que não há como se ter medo da transcorrência do rio depois do caminho feito, de outro lado temos como suporte o curso feito na escola técnica de sapateiro. Tudo isso atrelado à consciência total da escolha feita, como se não houvesse muito do que reclamar, uma vez que ele optou por criar condições novas de vida, abrindo mão de muitas coisas na vida para que viessem novidades

O curso técnico segue até hoje para ele como a base prática da vida, muito mais que algo teórico aprendido, remete, pelo entrevistado, ao valor do ofício e de como precisamos tê-lo para significarmos nossa própria vida. Depois do gravador desligado, o entrevistado fez questão de salientar para mim o quanto as pessoas se negam a aprender um ofício e utilizá-lo na vida. Em relação à própria constituição da identidade, encontramos as seguintes observações do entrevistado:

ENTREVISTADOR - Me diz uma coisa, o Senhor saiu então da Iugoslávia.
O Senhor se considerava Iugoslavo ou Croata?
ENTREVISTADO - Eu sempre me considerei Croata.
ENTREVISTADOR - Mesmo o país sendo ...
ENTREVISTADO - É ! Mesmo o país ...eu tenho até documento da da
antiga Iugoslávia mas eu fala que eu sou Croata meus país são Croatas
porque lá é diferente do que diz no Brasil, no Brasil diz quem nasce no
Brasil é tudo brasileiro não é isso? No leste europeu não é assim, que teu pai,
teu avô bisavô, você pertence a isso aí, por isso tem essas briga, essas
confusões lá, entendeu?, porque você nasce na Croácia, 400 anos, mas você
pode continuar sendo Sérvio, você entendeu, a mesma coisa se você nascer
no Brasil, negros são africanos, africanos é brasileiro não é isso? Nas
Américas é assim, na América toda é assim... eu me considerava Croata lá,
eu vim para cá para São Paulo...me deram documento Croata, tinha
manifestações pela Croácia contra a Iugoslávia.

Há um entrecortar de informações e um cruzamento de valores, que nos demonstram como é difícil definir como nos sentimos quanto à identidade e como ela pode se transformar de acordo com as viagens que fazemos.

Em princípio, ele se sentia Croata por conta da tradição familiar, mesmo tendo documentos da Iugoslávia. Ao chegar ao Brasil, recebeu documentos de Croata, porém, observava pessoas totalmente diferentes umas das outras tanto social quanto etnicamente chamarem-se brasileiras, isso tudo ligado com as imagens da infância de um povo inteiro brasileiro, chorando junto pela perda da copa do mundo de 1950. 
Essa imagem que parece percebida pelo entrevistado se revisita e se projeta pelos órgãos do Estado, pela economia de mercado, pelas escolas, enfim, é como se forjássemos nossa própria identidade numa institucionalização direcionada ao estereótipo e a espelhássemos pelo mundo, que muitas vezes nos vê como a solução para a globalização e para a convivência com o diferente. Nisso tudo, o futebol se torna uma das instituições mais fortes e poderosas do Brasil.

Ainda no terreno da identidade, notamos como ela se transforma e se reinventa no próprio entrevistado e como ele não saiu isento das viagens que fez por aqui ao falar do retorno. Retorno esse que não ocorreu para a Iugoslávia, ocorreu para a Croácia revigorada após a queda do regime comunista:

ENTREVISTADOR - Quando a Iugoslávia acabou eu voltei lá ... 90, mas eu voltei como cidadão brasileiro ...

O menino que saiu da Croácia com 19 anos retorna o homem com 51 anos, mas tudo havia mudado, a nova Croácia já não era como a Croácia antiga e o nosso viajante também já não era o mesmo: antes ele era um Iugoslavo que se sentia Croata embora não tivesse o documento da Croácia, depois ele era Croata com documento brasileiro a entrar na antiga Iugoslávia, enfim, um viajante a perceber suas divisões e seus movimentos:

A "identidade" só nos é revelada como algo a ser inventado, e não
descoberto; como alvo de um esforço, "um objetivo"; como uma coisa que
ainda se precisa construir a partir do zero ou escolher entre alternativas e
então lutar por ela e protegê-la lutando ainda mais - mesmo que, para que
essa luta seja vitoriosa, a verdade sobre a condição precária e eternamente
inconclusa da identidade deva ser, e tenda a ser, suprimida e laboriosamente
oculta. (BAUMAN, 2005, p.22)

Até que ponto há algo de "inventado" em nossa "descoberta"? Lembrando tanto o trajeto antropológico (DURAND, 1997, p.41), quanto a jornada interpretativa (FERREIRA SANTOS, 2005, p.68), notamos, na chamada contemporaneidade ou modernidade tardia, um "encontro" entre muitos conceitos em que nos utilizávamos do "desencontro" para compreendê-los, ou seja, o "inventado" pode muito bem não estar tão distante do "descoberto". 
Hoje em dia, essa verdade aflora muito mais em nós. A própria noção de língua é diretamente relacionada a uma unificação histórica, estrutural, monetária, jurídica, bélica, territorial e educacional. Chamavam-se, de um lado, as línguas clássicas (Sânscrito, Grego e Latim) aquelas de impérios que formatavam a base conceitual e cultural de muitos povos filhos de tal tradição; por outro lado, línguas vernáculas (Português, Espanhol, Francês), aquelas advindas da identidade de um povo criador e criatura do Estado Moderno.

Na contemporaneidade, com a fluidez do Estado moderno, a língua também se fluidifica e se projeta muito mais no encontro entre culturas que nas oposições entre países. Um exemplo interessante disso são três nações diferentes falando a mesma língua com escritas diversas (Croácia, Sérvia e Bósnia). Talvez por isso nosso entrevistado não se incomode tanto com a sua forma de falar o português, talvez por isso muitos estudos contemporâneos de linguagem estejam imbuídos da percepção das variantes linguísticas socioculturais, do estudo de línguas indígenas e aborígenes. 


\subsection{Resumo da Segunda História}

Nosso segundo entrevistado nasceu no Brasil, estudou em Porto Alegre em um Colégio de Jesuítas, que lhe deu, desde cedo, uma educação vinculada às questões sociais e políticas. Teve, também, farta educação musical.

Quando chegou à idade universitária, por conta do regime militar brasileiro, governo Médici, optou por autoexilar-se e foi, com dois amigos, para o Chile.

No Chile, solicitou bolsa de estudo e estadia em uma Universidade. Passou então a estudar economia e tocar música nas festas universitárias.

Depois de seis meses, como um amigo foi estudar Filosofia e outro amigo retornou ao Brasil, nosso entrevistado foi morar em Paris. Morou oito anos por lá, onde estudou música erudita e étnica em Sourbonne e tocou em vários eventos, que trouxeram a ele, através dos festivais de música, outras viagens, uma delas a Nova Iorque.

Por conta da filha, retornou a Porto Alegre, passou também dois anos em Florianópolis. Morou um ano em Porto Velho acompanhando a esposa, que era ligada ao ambientalismo, Morou também dois anos em Brasília, dois anos e meio em Cuiabá e veio para São Paulo, onde se encontra, por enquanto...

Em toda essa trajetória, ocupou-se de música, praticando e estudando. Especializou-se em música indígena e produziu trabalhos na área de pesquisa e produção, financiados por ONGs. 


\title{
5.4. Comentários à segunda história
}

\author{
Se partires um dia rumo a Ítaca, \\ faz votos de que o caminho seja longo, \\ repleto de aventuras, repleto de saber. \\ Tem todo o tempo Ítaca na mente. \\ Estás predestinado a ali chegar. \\ Mas não apresses a viagem nunca. \\ Melhor muitos anos levares de jornada \\ e fundeares na ilha velho enfim, \\ rico de quanto ganhaste no caminho, \\ sem esperar riquezas que Ítaca te desse. \\ Uma bela viagem deu-te Ítaca. \\ Sem ela não te ponhas a caminho. \\ Mais do que isso não lhe cumpre dar-te. \\ Ítaca não te iludiu, se a achas pobre. \\ Tu te tornaste sábio, um homem de experiência, \\ e agora sabes o que significam Ítacas.
}

(KAVÁFIS, 2006, p.146)

Após terminada a entrevista, por ocasião do acaso, tive ou quis ter uma longa caminhada. Caminhei durante uma hora e meia conversando, com um grande amigo, e pensando. Tantas histórias e tantas viagens! Quando, como, em qual estrada seria meu encontro com ele? Ele me pareceu, então, um Ulisses, retornando ao Brasil, sua grande ilha de Ítaca.

O ENTREVISTADO viveu na França durante muitos anos, porém, todo tempo tinha sua Ítaca/Brasil na mente, seja nos estudos de música étnica, seja nos shows que dava de música brasileira ou latina. O Brasil tinha-lhe dado uma grande viagem: a viagem ao próprio Brasil! Viagem que parece até agora continuar: a descoberta do que, de fato somos.

ENTREVISTADO - Na verdade, eu tenho uma coisa dentro de mim e essa busca acho que até é da minha geração sabe da formação do homem brasileiro ... entendeu ... que tem a ver com Anita Malfati ... desse Brasil dependente ... colonizado ... me fascina essa trilogia e eu vi que nessa trilogia o índio não entrou como tese... nós somos brancos, índios e africanos, mas o índio não entrou como formação não entrou na universidade... a análise que a gente tem é completamente europeia .... gente tem uma categorização do índio completamente deturpada né ... linguagem do colonizador ... do dominador .... 
A antropofagia de Anita Malfati e Oswald de Andrade, à luz de nosso ENTREVISTADO e de tudo o que tem sido discutido aqui até então, traz em si um daqueles deliciosos paradoxos da modernidade tardia: o brasileiro é aquele que se mistura com o estrangeiro, com o índio e com o negro, todavia, ao se misturar, deixa de "ser alguém", uma vez que a noção tradicional de "ser alguém" é diferenciar-se do outro. Como "serei alguém" se em vez de me diferenciar do outro, misturo-me com ele?

"E agora sabe o que significam Ítacas". Isso tudo me fez pensar em, verdadeiramente, qual seria a Ítaca dele e qual seria a minha Ítaca. Ele viajou tal como Ulisses, com idas e vindas, estalagens e estradas. Chegou em Paris para, inicialmente, se encontrar com o existencialismo de Sartre, com a militância política solidária. Encontrou, além disso tudo, estudos sobre música étnica brasileira que pouco existiam e existem no Brasil. Retornou à Porto Alegre por conta da filha. Passeou por Porto Velho e Cuiabá para se encontrar com os índios e os estudos musicais contemplados em Paris.

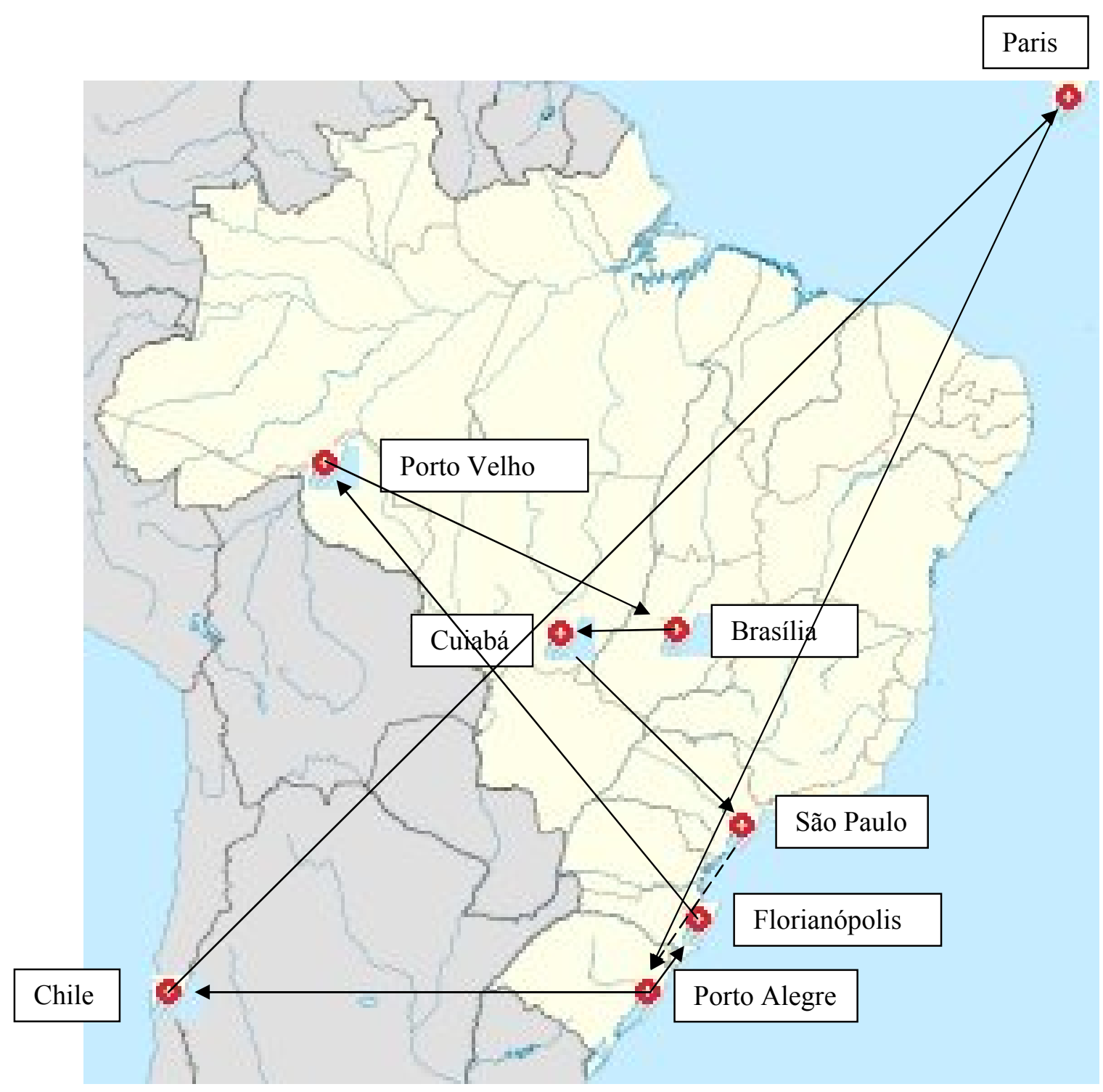


Vejamos, agora, como foi o caminho de Ulisses:

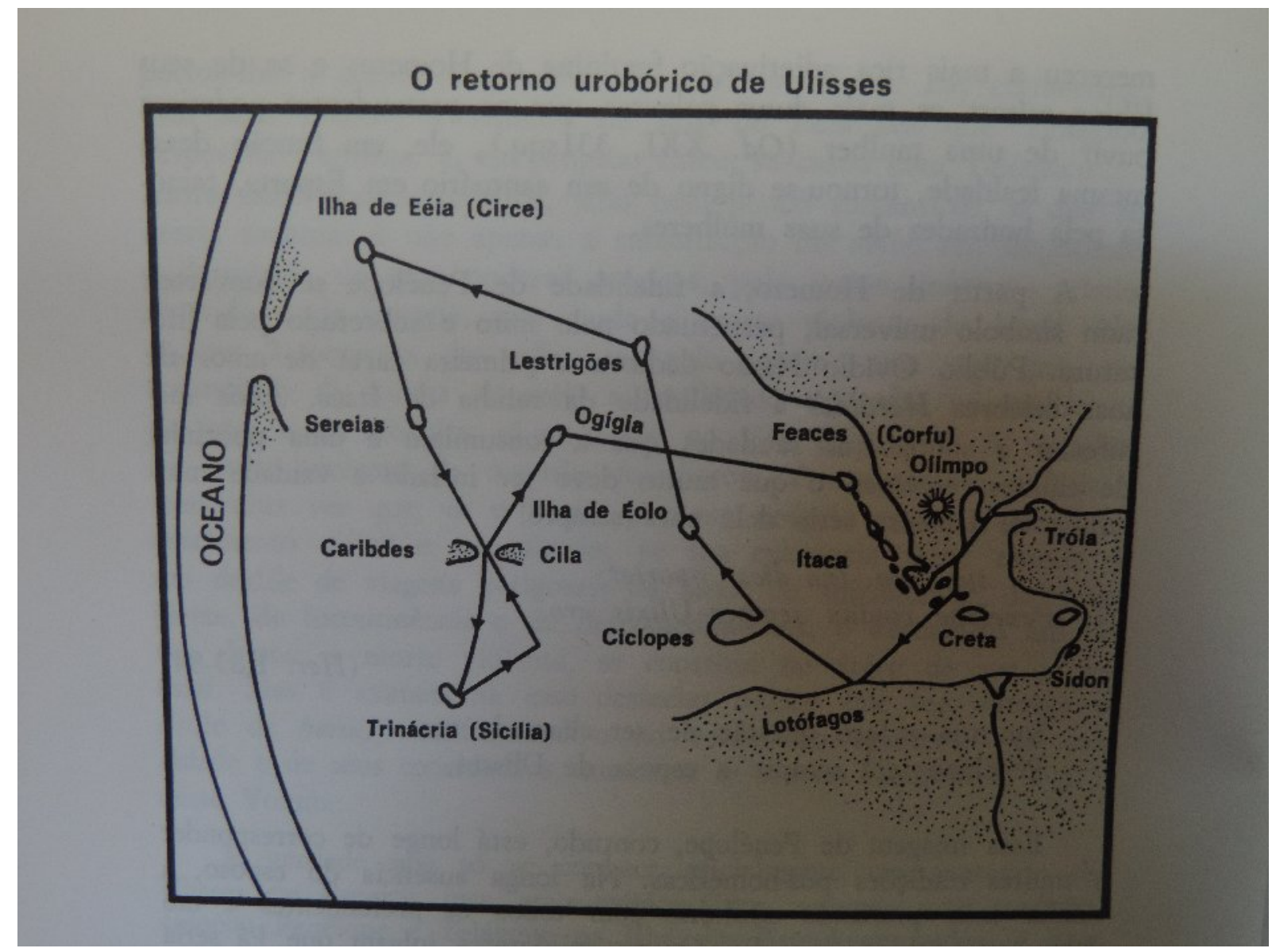

(BRANDÃO, 1992, p.328)

Ambos passeiam rotas intrincadas que se cruzam, aproximando-se e distanciando-se do ponto de origem, um retorno urobórico, tal como a serpente que morde a própria calda. "Esse símbolo contém ao mesmo tempo as ideias de movimento, de continuidade, de autofecundação e, em consequência, de eterno retorno" (CHEVALIER, 1993, p.922).

A Ítaca pode ser a contínua viagem, um eterno retorno à origem, condizente com a antropofagia e seus paradoxos, ou seja, o sentido da identidade se encontra no contínuo movimento. Assim que chegarmos ao destino, retomamos a viagem ou nos perderemos entre sermos nós, sermos o outro, sermos o encontro entre nós e o outro.

No decorrer da viagem, os vários epítetos que recebemos circundam-se com a ideia de "estrangeiro". Assim Ulisses foi tratado, por exemplo, quando se apresentou como suplicante à rainha Arete, esposa de Alcino. "Um estrangeiro suplicante é como um irmão / para o homem que atinja o mínimo de bom senso.” (HOMERO, 2011, p. 255) 
No entanto Ulisses chora quando fazem uma assembleia para tratar as formas de fazer com que retorne à própria pátria, quando cantam sobre as glórias de seu passado. Então Alcino pede que Ulisses conte sua história de vida.

Diz-me o nome pelo qual te tratam tua mãe e teu pai, assim como todos os que habitam perto da tua cidade. Pois entre os homens não há ninguém que não tenha nome, seja ele de condição vil ou nobre, uma vez que tenha nascido: mas os pais dão sempre um nome aos filhos, quando nascem. E diz-me qual é a tua terra, qual é a tua cidade, para que até lá as nossas naus te transportem, discernindo o percurso por si sós. (HOMERO, 2011, p.255)

Ulisses, então, após afirmar que não existe na vida fim mais belo que escutar o canto de um aedo (poeta/cantor), após se perguntar por qual peripécia começaria sua história de vida. Decide que ele começará sua história pelo seu nome, ação sugerida anteriormente por Alcino: "Sou Ulisses, filho de Laertes, conhecido de todos os homens" (HOMERO, 2011, p.257).

Quanto ao nosso ENTREVISTADO, quando fizemos uma "assembleia" para the escutar: gravador ligado, olhos e ouvidos acesos à cata da história de sua vida e de suas peripécias como grande e destemido viajante; ele diz com uma métrica certeira suas primeiras palavras:

ENTREVISTADO - Eu sou músico.

Estamos diante do aedo, que não precisa de nome algum, definição alguma, história alguma. Parece que, para ele, o fato de ser músico lhe abre todas as possibilidades possíveis: de viajar distanciando-se e aproximando-se de sua origem, de cantar para Brigite Bardot ou para um índio Yanomami, de buscar o existencialismo ou a militância solidária, de aproximar-se da música indígena e por ela escutar a alma de brasileiros que cantam para ouvidos surdos.

\section{ENTREVISTADO-}

"Escreva aí no seu caderno essas memórias

De uma geração que contemplou no tempo que passou, passou, as vossas glórias

Escreva aí a moda de 71, escreva aí a moda de 71

Fita no cabelo, filho nas costas, pé na estrada

$\mathrm{Na}$ Holanda, na Turquia, Londres, Bahia

Ou Enseada (ou Encruzilhada)

Escreva aí que tentamos morar juntos

Escreva aí que chegamos a viver juntos

Lavrando e semeando o mesmo chão

Fazendo e comendo o mesmo pão

$\mathrm{E}$ a fome foi maior do que a vontade de mastigar cada pedaço

Escreva aí que Deus ainda não foi achado

E houve quem correu e quem ficou sentado

Nessa nova era 
Que falou desse novo homem

O tempo que passou, o fumo que queimou e ardeu nos olhos

De quem sonhou amar"

(HARTLIEB, 2016)

"Novo homem" cantado por um amigo seu também de Porto Alegre. O filho não dentro de uma casa fixa e protetora, mas nas costas do pai viajante. O pé na estrada, devorando o mundo inteiro naquela fome juvenil de tudo abocanhar e curtir, tal como uma criança brinca e curte. Essa juventude que vê a viagem e a vida pelo próprio prazer de viajar e de viver já foi levantada pelo nosso primeiro ENTREVISTADO. Amor fati , "Deus ainda não foi achado". A graça em não encontrarmos Deus ainda possibilita nosso eterno retorno viajeiro e nos liberta, por um tempo, de uma metafísica de conceitos prontos e sedentários.

A música, a antropofagia e o lúdico ajudam-nos a conviver com os paradoxos, que nos transpassam por toda a viagem. Outro deles, por exemplo, é quando, extremamente distante de qualquer cidade, depois de horas rio a dentro, ele se encontra com o brasileiro mais legítimo:

ENTREVISTADO - botamos as redes ... fomos dormir ... no dia seguinte eu acordei ... e lá tem vários tipos de índios tudo misturado e quando eu acordei ... parecia que eu tava no meio da praça da sé ... tinha índio parecido até com gaúcho lá ... entendeu...

Nosso ENTREVISTADO foi até Paris e lá se encontrou com a música étnica brasileira. Depois nosso ENTREVISTADO foi ao cerne do índio brasileiro, nas aldeias mais longínquas possíveis do interior de sua Ítaca, e se encontrou com a praça da sé, reduto da cidade e seus ares metropolitanos. Talvez o homem esteja inteiro em todo o lugar e as cidades, países, estados, não passam de nomes vazios dados a um Ulisses, que, na verdade, se chama, aedo, músico, andarilho. 


\subsection{Resumo da Terceira História}

Nossa terceira história não foi uma entrevista gravada e transcrita.

Trata-se de seleções o capítulo Memorial da Tese de Doutorado de SORAIA CHUNG SAURA (SAURA, 2008). A proposta da Tese é descrever o imaginário mítico do bumbameu-boi e suas implicações com a educação não oficial ou não escolar.

Dentro da pesquisa, no capítulo Memorial, a autora escreve um texto em que conta sua própria história à sua filha. Nesse texto, ela conta o caminho de sua família, a começar pelos seus avós, posteriormente, seus pais e dela mesma.

Esse texto é nossa terceira história.

Ela se aproxima bem da contação oral de histórias e trata do tema da migração.

Temos nela uma sequência de viagens contadas e interpretadas pela autora.

Seu avô nasceu na Coreia e foi estudar por conta própria na China.

Após a segunda guerra mundial, a Coreia ficou dividida em duas partes. Ele ficou na Coreia do Sul, engajou-se nas forças armadas, ocupou um alto posto no batalhão de engenharia do exército sul-coreano. Ali nasceu a segunda filha.

Como a Coreia do Norte invadia a Coreia do Sul, empurrava os sul-coreanos para a ponta do arquipélago. Assim, em trânsito, nasceram os demais filhos de seu avô: um filho entre Seoul e Pusan, outra bem ao sul de Pusan e último em Seoul, após armistício militar.

Posteriormente, a família migrou para o Brasil em 1964.

A família inteira costumava trabalhar no comércio, dirigida pelo avô: churrasquinho grego, pastelaria, charutaria, bomboniere.

A autora nasceu em Piracicaba. Com dois meses, foi para Capivari e seus pais mudavam constantemente pelo Brasil. Moraram no Norte, Nordeste, Sul, São Paulo, Estados Unidos. Trabalhavam com artesãos populares.

Isso fez também com que a própria autora também viajasse bastante. $\mathrm{O}$ nascimento de sua filha fez com que diminuísse, porém, não interrompesse as viagens. 


\subsection{Comentários à Terceira História}

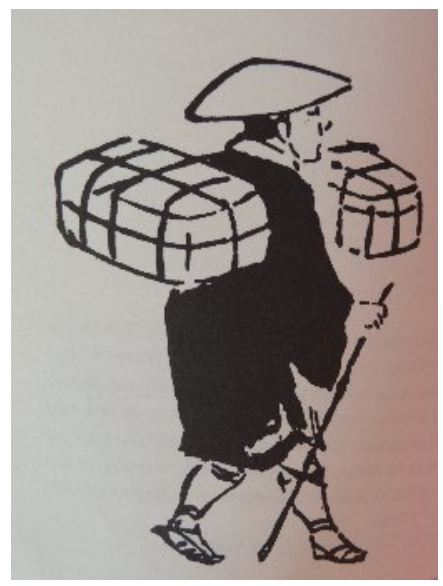

(BASHÔ, 2013, p.84) ${ }^{5}$

Luas e sóis (meses e dias) são viajantes da eternidade. Os anos que vêm e se vão são viajantes também. Os que passam a vida a bordo de navios ou envelhecem montados a cavalo estão sempre de viagem, e seu lar se encontra ali onde suas viagens os levam. Os homens de antigamente, muitos, morreram pelos caminhos, e a mim também, durante os últimos anos, a visão de uma nuvem solitária levada pelo vento inspirou contínuas idéias de meter o pé na estrada. (BASHÔ, 2013, p. 85)

Creio que, ao ler este trabalho, você, caro leitor, se sinta andarilho também nos conceitos, imagens e devaneios. Confesso que me sinto também assim ao escrever. A escrita não passa de uma grande linha, uma grande estrada sinuosa.

Este trabalho começou com a proposta de contemplação da História de Vida do migrante. O trabalho, de certa forma, iniciou-se estruturando-se nos moldes acadêmicos: busca de referências teóricas, leitura de bibliografia, entrevistas-piloto, aproveitamento das reflexões que as matérias na pós-graduação me traziam.

\footnotetext{
${ }^{5}$ BASHÔ apud (LEMINSKI, 2013).

${ }^{6}$ Idem ibidem.
} 
Com o passar do tempo de estudo e com as orientações recebidas, acabei, de repente, me vendo caminhando também na estrada, procurando esse algo desconhecido que os andarilhos procuram e sentindo como os alicerces fixos de metodologias não passavam de pequenas estalagens apenas a nos apontarem o dedo para a estrada, estrada esta em que o olhar se perde no infinito.

Senti-me e me sinto hoje um pouquinho como os migrantes, indo ao desconhecido: "vamos ver no que vai dar ... qualquer coisa, mudamos de rota". Após as duas primeiras entrevistas, saí por aí pensando na próxima história e perguntando a mim mesmo qual o ponto que eu queria chegar e qual seria minha terceira entrevista, enfim, "ver no que vai dar".

Percorrendo e cheirando o caminho, lendo textos sobre imaginário e mitohermenêutica, um pouco cansado das transcrições de entrevistas, que me pareciam trazer repetições ao mesmo ponto, tal como alguns ensaios acadêmicos e filosóficos que, a intenção de reforço e legitimação da tese, repetem muitas vezes os mesmos temas... Enfim, procurando olhar para outros lugares na paisagem do caminho, deparei-me com a tese de Soraia Chung (SAURA, 2008). Trata-se de uma Tese interessantíssima sobre o bumba-meu-boi e todas as questões ligadas ao imaginário popular e à educação cotidiana fora da escola, porém, o que me coube foi o capítulo Memorial, por conta da contínua andarilhagem por que passam as personagens da história contada.

Confesso que adorei o trabalho inteiro, mas foi o capítulo Memorial o que mais me impressionou.

Lá você tem uma História de Vida não contada para um entrevistador conhecido com documento para assinar, gravador ligado e todo o teatro acadêmico. Lá você tem uma História de Vida contada de uma mãe para uma filha bem pequena, simplesmente um registro e compreensão de uma vida inteira viajante, não somente interessada em contar das viagens, mas também em contar como tudo aquilo construiu uma família, movimentou uma linhagem, algo como os mais velhos, em volta da fogueira, contando aos mais novos, como tudo aconteceu num tempo em que ainda nada existia para as crianças.

A questão inicial percebida foi algo que já vinha surgindo, aos poucos, no meio do caminho: se uma das propostas é perceber a transcriação e o contínuo movimento dos motivos e ideias perante a verdade de cada indivíduo diante da vida, passagens, reentrâncias e estranhamentos que se encontram na estrada; então, talvez, não andemos sós, é aparente nossa solidão errante, andamos em grupo, migramos em grupo, como se nossas diferenças caminhassem de mãos dadas: 
Guarde sempre na lembrança que esta estrada não é sua

Sua vista pouco alcança, mas a terra continua

Segue em frente, violeiro, que eu lhe dou a garantia

De que alguém passou primeiro na procura da alegria

Pois quem anda noite e dia sempre encontra um companheiro

(MILLER, 1967)

Que diferença há entre andarilhagem da mãe e da filha (que anda pelas palavras da história da mãe)? Tudo viaja: a lua, o sol, os anos, as nuvens. Na história em questão, temos três gerações: o avô viajando pela Coreia, os pais viajando pelo Brasil e a autora também:

Por conta de seus casamentos a família aumentou, mas nunca se descolou do conjunto, e este bloco se movimenta através dos tempos, unido em todas as datas festivas e em todos os momentos difíceis.[...](SAURA, 2008)

E esse bloco, tal como os ciganos, tende a ficar no limite entre a fixação de valores para compor elementos iguais entre todos e a movimentação desses valores num cum-currere, também num enraizamento dinâmico nos termos de MAFFESOLI. Por conta disso, tanto o grupo quando elementos externos a ele assistem às suas identidades de modo plural, de difícil definição nos termos tradicionais:

Ela (referindo-se à mãe) também, bem abrasileirada, foi pouco reconhecida entre os seus. "Até que você fala bem o coreano", disse uma senhora na rua, para sua avó, que atônita, só conseguiu responder: "Eu sou coreana." (SAURA, 2008)

Tive que me desfazer de raízes e procurar outras ininterruptamente e hoje, quando invariavelmente me perguntam de onde eu sou - porque obviamente percebem que não cresci na cidade - tenho vontade de dizer que não sou de lugar nenhum, mas respondo sempre que sou do interior. (SAURA, 2008)

Por um lado, há o estranhamento dos coreanos ao ver alguém diferente deles, por conta da carga cultural conseguida durante as viagens, e igual a eles por conta da língua: o trânsito é um lugar difícil para classificação dos moldes identitários das nacionalidades e nacionalismos tradicionais como demonstrou BAUMAN. 
Por outro lado, a autora, da mesma forma que a mãe, não recebe uma classificação precisa e clara dentro do próprio Brasil. Interessantes as resoluções terminológicas que ocorrem nas capitais brasileiras. Quando o indivíduo não é do Brasil, dizem que é estrangeiro; quando o indivíduo é do Brasil, mas possui um jeito de falar diferente das capitais, dizem que é do “interior". Essa noção genérica de "interior" remete ao infinito de terra que existe no nosso país distante do litoral, lugar longe das influências externas e que produz, dentro de si, cultura e histórias que à luz, por exemplo, de Guimarães Rosa, podem se referir ao infinito interior de nós mesmos, de nossas origens e, quiçá, alguma ideia de essência humana:

O senhor tolere, isto é o sertão. Uns querem que não seja: que situado sertão é por os campos-gerais a fora a dentro, eles dizem, fim de rumo, terras altas, demais do Urucúia. Toleima. Para os de Corinto e do Curvelo, então o aqui não é o dito sertão? Ah! que tem maior! Lugar sertão se divulga: é onde os pastos carecem de fechos; onde um pode torar dez, quinze léguas, sem topar com casa de morador; e onde criminoso vive seu cristo-jesus, arredado do arrocho de autoridade.(ROSA, 2001)

Sugerimos aqui que o "sertão" é um "interior" mais distante, mais dentro, algum lugar "sempre mais para lá", algum lugar perdido em meio a tantos lugares fixos, certeiros e referenciais à sociedade. E para esse lugar, como se fosse uma casa paterna/materna, sempre eles retornavam, tal como nosso segundo entrevistado, viagem urobórica:

Sempre retornávamos para o mesmo canavial, com o prazer dos ciscos de cana caindo no quintal. (SAURA, 2008).

Notamos aqui que o retorno é definido como retorno ao "canavial" e aos "ciscos". Ela não diz nome de cidade, de país, de estrada. Isso tudo é referência para os livros e manuais geográficos, mas não para quem viveu e desfrutou, efetivamente, da terra. Nos relatos dos nossos "lares", é muito comum nos utilizarmos desses elementos auxiliares aos topônimos, uma vez que os topônimos, com a urbanização, possuem a tendência a deixarem de serem ligados à terra para se transformarem em nomes de pessoas: aí sim, os topônimos acabam esquecidos. 
Algo, ligado à terra, tende-se a reproduzir nossa "imaginação material" termo de BACHELARD, 2003. Na minha casa de infância, por exemplo, havia um pequeno, mas infinitamente belo manacá com flores brancas e roxas e um perfume muito gostoso nos finais de tarde. Eu saí de casa, e minha mãe, posteriormente, se mudou. Porém, quando retornei à casa de minha mãe, aquele novo apartamento (nova casa) parecia ter existido sempre, algo instintivo, talvez ligado até ao cheiro de móveis ou de roupas. Lá não havia mais o manacá, mas minha mãe contemplava um ipê, que, embora ficasse na calçada em frente à janela do quarto dela, adentrou em meus pensamentos e em minha casa onírica:

A casa onírica é um tema mais profundo que a casa natal. Corresponde a uma necessidade mais remota. Se a casa natal põe em nós tais fundações, é porque responde a inspirações inconscientes mais profundas - mais íntimas - que o simples cuidado de proteção, que o primeiro calor conservado, que a primeira luz protegida. A casa da lembrança, a casa natal, é construída sobre a cripta da casa onírica. Na cripta encontra-se a raiz, o apego, a profundidade, o mergulho dos sonhos. Nós nos "perdemos" nela. Há nela um infinito. (BACHELARD, 2003, p. 77).

Infinito do "interior", do "sertão", de nós mesmos. Sonhamos com ele como um desejo, em descobrir em com ele sempre fora.

Quanto ao encontro com o grupo familiar que migra, meus pensamentos também voam à cata das ruas que meu pai andava na praça da república, da rua do primeiro emprego de minha mãe quando ela chegou em São Paulo, dos pensamentos possíveis do meu avô criança saindo da aldeia no norte de Portugal e chegando ao porto de Santos no início do século: viajamos em grupo quando nos reconhecemos nas histórias, talvez a experiência do reconhecimento no outro seja nossa maior aprendizagem, talvez aprender seja permitir que a viagem do outro se misture com nossa própria viagem e percebê-las não iguais, mas entrelaçadas.

Outro aspecto a ser levantado na história contada para a filha, é que, em alguns momentos, as palavras saem do papel e projetam-se sobre a enunciação discursiva, momentos em que conseguimos "ver/escutar" as palavras, a mãe falando com a filha, educando-a com as marcas do seu próprio corpo: 
Em um dos meus trabalhos na Amazônia tive que saltar de um avião em chamas e dei sorte de cair em uma tribo de índios que julgou que eu era enviada do céu, tendo por isso cuidado de mim. Vê este dedo um pouco torto? Quebrei-o nesta queda. Nas tribos indígenas é que nos sentimos bem em casa, porque eles se comunicam baixo como a nossa família, não possuem pelos pelo corpo, mais escutam do que falam e não importa que língua de qual etnia, esta é sempre um dialeto que nos soa muito familiar.[...](SAURA, 2008)

Um "dedo um pouco torto" mostrado a um filho, possivelmente, educará e marcará muito mais o imaginário da criança e suas constituições sobre a vida e sobre as experiências que livros e livros e textos a serem lidos, pois se trata da experiência marcada, vestígios de vida, manchas, como tratou SILVEIRA JÚNIOR:

A educação se dá entre, na dinâmica do entre, na "energia" do entre, a "mancha". O entre não é estático, mas um movimento como um lugar na alma. O corpo movente, o pensamento movente. Assim a travessia é educação. Condição de transição, convulsionada e pouco pacífica. Que mancha o corpo e acena para um mais além. (SILVEIRA JÚNIOR, 2008 p.109).

Numa sociedade em que se procura, muitas vezes, tirar-se manchas da vida com plásticas e padronizações de corpo e mente, em que se joga fora objetos antigos que falam pelas marcas do tempo, em que se tenta consertar um machucado... enfim, numa sociedade que padroniza comportamentos, o migrante e suas manchas é extremamente assustador.

Outro aspecto remete-se à familiaridade com as línguas indígenas, mesmo desconhecendo-as. Há no encontro étnico uma transcriação em seu princípio mais profundo: não entendo o que você fala, mas entendo como você fala e isso é o que mais importa nesse conjunto de aparentes desentendimentos. A não compreensão da língua permite a fluência de outros elementos e imagens.

Quanto à resposta negativa comum ao estrangeiro, perceptível nas crises de migração pósmodernas, não creio que todo esse horror a refugiados e migrantes seja apenas por questões financeiras no acolhimento dos países que os recebem. Creio que os migrantes também trazem uma proposta muito forte de movimentação de comportamentos, sotaques, valores morais e conseguem reinventar um país em muito pouco tempo. 
$\mathrm{Na}$ nossa terceira história, temos uma neta de um coreano que se encantou com a riqueza de um ritual interno num país assustadoramente distante de onde seu avô veio, o bumba-meu-boi. Possivelmente, haverá alguma alteração na significação do ritual depois da análise dela, por conta de seu olhar influenciado pela tradição oriental de seus antepassados.

Por outro lado, talvez essa filha retorne à Coreia e, com sua história, modifique também significações dos coreanos tanto sobre o Brasil quanto aos estrangeiros em si: é um trajeto de modificações e interferências que vem e vai.

Eu possuo muitos alunos cujo desejo é migrar para fora e viver por lá. Cada um que vai é como se fosse uma semente a ser jogada por lá, mas uma semente que viajou muito, misturouse muito, e sua aparente despersonalização talvez seja seu maior traço de humanidade. 


\section{CONSIDERAÇÕES FINAIS}

Este trabalho começou com um exercício "postural" de tirar meus olhos da lousa e volvê-los para os alunos. Encontrei, por conta do colégio que leciono, vários descendentes de orientais. Suas histórias e aventuras advindas das histórias e aventuras de seus pais trouxeram-me outro exercício "postural": elevar meus olhos à estrada de letras e devaneios e iniciar meu caminho pelas histórias deles.

Não me considero, propriamente, um viajante, mas confesso que, após o início deste trabalho, fiz muitas e diferentes viagens, desde físicas e geográficas até conceituais e imagéticas, por todos os autores que me foram apresentados durante a pesquisa.

Certa feita, me perguntei onde se encontra o conhecimento e a aprendizagem? Nas cidades (escolas) ou nas estradas (caminhos da vida)? Já pensei que estava nas cidades, já pensei que estava nas estradas. Hoje, até agora, penso que está em ambas, ou melhor, no trânsito entre ambas. Tal como me disse MESAC: a escola é uma grande estalagem, ou me diz a própria palavra "Educação" que, em latim, remete-se a "alimentar", "nutrir", mas também "conduzir para fora".

A tradição que recebemos, fundamentada e focalizada na construção de identidades nacionais e burocracias estáticas alicerçando essas identidades, constrói uma ciência e, por conseguinte, uma educação voltadas mais "para alimentar" que para "conduzir para fora", ou seja, muito mais para as cidades que para as estradas.

A pós-modernidade e sua fluidez, seu enraizamento dinâmico, seu multicolorido cultural, direciona-se para as estradas, para os processos de transcriação, ou seja, de transformações contínuas de sentido, que se metamorfoseiam, como os viajantes, como nós mesmos nas estradas de nossas vidas.

Há, dessa forma, que se conviver, primeiramente, com um profundo estranhamento, pois sentimo-nos, muitas vezes, como traidores, tal qual MESAC ao comentar as interpretações sobre si mesmo e seus textos quando na qualificação deste trabalho ao ler meus comentários sobre seu próprio doutorado. 
Se alguns países estranham, muitas vezes violentamente, os migrantes, dentre outras coisas, é por toda essa volaticidade presente neles e pelo momento histórico pós-moderno por que passamos.

Imaginemos, por exemplo, nós mesmos observando nossas histórias de vida e questionando se aquela história que contamos é de fato de nós mesmos, se é verdade, ou se é relevante realmente.

A verdade, na estrada, não é uma verdade fixa, ainda mais quando contada. Se nós somos o conjunto de histórias que contamos de nós mesmos e elas são verdades transitórias, somos nós, então, seres transitórios, cuja existência esfaleça-se diante do fim do caminho, perigoso vazio de verdade, de história, de identidade.

A Pedagogia da escolha surge como uma pequena vereda existencial: escolhemos existir e jogar o jogo da vida nessa imensa transcriação de sentidos. Escolhemos existir, mesmo na possível inexistência de sentido algum.

Volta-nos novamente o migrante, aquele que tanto tememos, por ser diferente, a nos ensinar: "seu eu vivo aqui na sua terra, tão diferente da minha, onde tantas pessoas fazem coisas que para mim não possuem sentido nenhum, então, você pode viver a sua vida nessa pósmodernidade louca com sua loucura de troca de sentidos em que, ao mesmo tempo somos tudo e nada."

Ao perguntarmos a eles como fazem isso ou porque migraram, advêm respostas igualmente diferentes e transcodificadas de sentido: "migrei porque eu era jovem" (nosso primeiro entrevistado), "migrei para ver Sartre tomando café" (nosso segundo entrevistado), "já praticamente nasci migrando, é de família” (nossa terceira história).

Mesmo que existam motivos políticos, econômicos, sociológicos para as correntes migratórias, ao que parece, não são eles tão destacados nas histórias de vida ou nos diários dos viajantes em si, daqueles que, de fato, estão no jogo.

Isso talvez porque na história de vida perpassa um recontar-se, um redescobrir-se, que escapa das racionalizações burocráticas, permitindo que entremos numa imaginação material mais profunda, por exemplo, ao retornarmos uroboricamente ao mesmo canavial (terceira história), ou ao Brasil indígena mais profundo (segunda história), ou ao encontrarmos a Croácia no Brasil, por conta da formação da Iugoslávia (primeira história). 
Uma das motivações maiores a procurarmos desafios e novos caminhos é a percepção de não temos "nada a perder". Se estamos nus, sem casa, sem comida e tudo o que temos é um barco e um rio; entramos no tal barco e seguimos, porque nada ficou para trás.

Creio que tanto o migrante quando a pós-modernidade nos trazem essa consciência: de fato, nós, realmente, não temos nada a perder, porque tudo o que possuímos desfaz-se e transfigura-se com o tempo e o espaço, mesmo nossas histórias, nossos diplomas, dinheiro, parentes e tudo o que a fixação burocrática social nos traria de segurança provisória na vida.

A noção de viagem, de caminho (que não precisa, necessariamente, ser uma viagem física geográfica) pode ser uma das propostas educacionais intrínsecas: "pé na estrada", "aventurese". É difícil quantificar o tamanho das implicações sociais que isso pode trazer, mas percebemos o movimento das pessoas para isso e a reação das instituições tradicionais.

Da mesma forma que a integração com a continuidade de estrangeiros e viajantes na Grécia antiga trouxe modificações de pensamentos e interpretações, possivelmente, será uma contação de histórias com o estrangeiro dentro de nós, que trará a consciência do contínuo movimento de nossas vidas.

É assim, que, através das histórias dos outros, conto a vocês e a mim mesmo um pouco da minha história, das viagens que fiz pelas viagens deles e de como isso tudo me fez sentir vivo nessa imensa imprecisão de significados que é a vida. 


\section{REFERÊNCIAS}

ASSIS. Machado de. O espelho in: Obra Completa. Rio de Janeiro: Nova Aguilar, 1994. 98p. Publicado originalmente por Lombaerts \& Cia 1882 . Rio de Janeiro.

ALMEIDA, Rogério de. Aprendizagem de Desaprender: Machado de Assis e a Pedagogia da Escolha. Educ. Pesqui, São Paulo, v. 39. N. 4 dez 2013.

Disponível em: $\quad<$ http://www.scielo.br/scielo.php?script=sci_arttext\&pid=S151797022013000400012\&lng=pt\&nrm=iso $>$ acessos em $11-$ dez. 2014. http://dx.doi.org/10.1590/S1517-97022013000400012.

BACHELARD, Gaston. Devaneio e Cosmos. in: A Poética do Devaneio. São Paulo: Martins Fontes, 2009. Tradução: Antonio de Pádua Danesi. 205p.

Antônio de Pádua Danesi. 242p.

A Poética do Espaço. São Paulo: Martins Fontes, 2008. Tradução . A Terra e os Devaneios do Repouso. São Paulo: Martins Fontes, 2003. Tradução: Paulo Neves.

A Água e os Sonhos. São Paulo: Martins Fontes, 2002. Tradução Antônio de Pádua Danesi. 202p.

Nietzsche e o psiquismo ascencional in: O ar e os sonhos. São Paulo: Martins Fontes, 2001. Tradução de Antonio de Pádua Danesi.275p.

BAUMAN, Zygmunt. Identidade. Rio de Janeiro: Jorge ZAHAR Editor, 2005. Tradução: Carlos Alberto Medeiros. 112p.

BAPTISTA, Arnaldo et al. Uma pessoa só in: Lóki? São Paulo: PolyGram, 1974.

BARROS. Manoel de. RETRATO DO ARTISTA QUANDO COISA in: Poesia Completa. São Paulo: Leya, 2010. 493p.

BILATE, Danilo. A resposta afirmadora do Amor Fati in: A Tirania do Sentido: Uma Introdução a NIETZSCHE. Rio de Janeiro: MAUAD, 2011. 94p.

BRANDÃO, Junito de Souza. Ulisses: O Mito do Retorno in: Mitologia Grega. Rio de Janeiro: 1992. 407p.Volume III. 
CIAMPA, Antonio da Costa. Identidade Humana como metamorfose: A questão da família e do trabalho e a crise de sentido no mundo moderno. São Paulo: Interações, 1998. Vol III, Número 6 jul/dez 1998. Texto com acréscimos e modificações da comunicação oral feita em 23 de agosto de 1998 na mesa redonda.

CICERO, Antonio. Nihil in: Porventura. Rio de Janeiro: Record, 2012. 79p.

CAMÕES, Luis Vás de. O tempo acaba o ano, o mês e a hora. 2013 Disponível em: http://www.ligia.tomarchio.nom.br/poetas camoes.htm.

CAMPOS, Haroldo. Transcriação. São Paulo: Perspectiva, 2013. 232p.

CAMPBELl. Joseph. O Herói de Mil Faces. Tradução Adail Ubirajara Sobral. São Paulo: Pensamento, 2009. 414p.

CASTELLS, Manuel. A construção da Identidade. in: O Poder da Identidade. São Paulo: Paz e Terra, 2010. Tradução: Klauss Brandini Gerhardt. 530p.

CHEVALIER, Jean e GHEERBRANT, Alain. Dicionário de Símbolos. Rio de Janeiro: José Olympio, 1993. Tradução Vera da Costa e Silva. 996p.

COLOM, Antoni J. A teoria do caos ou a desconstrução da teoria. in: A (des)construção do conhecimento pedagógico. Porto Alegre: Artmed, 2003.

DERRIDA, Jacques. O significante e a verdade. in: Gramatologia. São Paulo: Perspectiva, 1973. Tradução Miriam Schnaiderman e Renato Janini Ribeiro.

DURAND, Gilbert. As Estruturas Antropológicas do Imaginário. São Paulo: Martins Fontes, 1997. Tradução: Hélder Godinho. 551p.

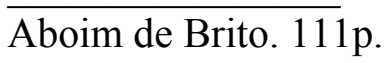

A imaginação simbólica. Lisboa: Edições 70, 1993. Tradução: Carlos

ELIADE, Mircea. O Mito do Eterno Retorno. São Paulo: Mercuryo, 1992. Tradução José Antonio Ceshin. 175p.

FERREIRA-SANTOS, Marcos e ALMEIDA, Rogério de. aproximações ao imaginário bússola de investigação poética. São Paulo: Képos, 2012.

FERREIRA-SANTOS, Marcos. O Espaço Crepuscular: Mitohermenêutica e Jornada Interpretativa em Cidades Históricas in: Ritmos do Imaginário. (org. ROCHA PITTA, Danielle Perio). Recife: Editora Universitária UFPE, 2005, 209p. 
Crepusculário. São Paulo: Zouk, 2005-A. 207p.

FOUCAULT, Michel. A Coragem da Verdade. São Paulo: Martins Fontes, 2011. Tradução de Eduardo Brandão. 339p.

O governo de si e dos outros. São Paulo: Martins Fontes, 2010. Tradução de Eduardo Brandão. 380p.

GESSINGER, Humberto. Longe Demais das Capitais. In: Longe Demais das Capitais. São Paulo: RCA, 1986.

GIRALDES, Antônio Roberto. Mestres e Heróis: Mitohermenêutica da Formação de Identidade de Professores. São Paulo, 2011 (Dissertação de Mestrado em Educação Departamento de Cultura e Organização da Faculdade de Educação da Universidade de São Paulo. 132p.

GUSDORF, Georges. Professores para quê? Para uma Pedagogia da Pedagogia. São Paulo: Martins Fontes, 2003. Tradução M.F. 257p.

HALL, Stuart. A identidade cultural na pós-modernidade. Tradução Tomaz Tadeu da Silva e Guacira Lopes Louro. Rio de Janeiro: DP\&A, 2006. 102p.

Pensando a Diáspora - Reflexões sobre a terra no exterior. In: Da Diáspora - Identidades e Mediações Culturais. Belo Horizonte: Editora UFMG, 2009. Tradução: Adelaine La Guardia Resende. 410p.

HARTLIEB, Carlos.

Disponível em: http://poaemcena.blogspot.com.br/2012/09/memorias-uma-homenagemcarlinhos.html

HJELMSLEV, Louis. Prolegômenos a uma teoria da Linguagem. São Paulo: Perspectiva, 1975. Tradução: J. Teixeira Coelho Neto. Edição Original, 1943.

HOMERO. Odisseia. São Paulo: Penguin Classics Companhia das Letras, 2011. Tradução de Frederico Lourenço, Notas de Bernard Knox. 574p.

JUNG, Carl Gustav. Instinto e Inconsciente. In: A natureza da psique. Tradução: Padre Dom Mateus Ramalho Rocha. Rio de Janeiro: Vozes, 1998. 402p.

KNOX, Bernard. Édipo em Tebas: O herói trágico de Sófocles e seu tempo. São Paulo: Perspectiva, s.d. Tradução: Margarida Goldstyn. 150p. 
LARROSA, Jorge. Nietzsche \& A Educação. Belo Horizonte: Autêntica, 2009. Tradução de Semíramis Gorini da Veiga. 119p.

LEMINSKI, Paulo. Bashô, a lágrima do peixe in: Vida - 4 biografias. São Paulo: Companhia das Letras, 2013. 389p.

LOPES, Edward. Fundamentos da Lingüística Contemporânea. São Paulo: Cultrix, 1989.

KAVÁfIS, Konstantinos. Ítaca in: Poemas. Rio de Janeiro: José Olympio, 2006. Tradução de José Paulo Paes. 234p.

KLINK, Amyr. Mar sem fim. São Paulo: Companhia das Letras, 2000.

MACHADO, Roberto. Zaratustra, a tragédia nietzschiniana. Rio de Janeiro: Jorge Zahar, 2001.

MAFFESOLI, Michel. Saturação. São Paulo: Iluminuras, 2010. Tradução de Ana Goldberger. 109p.

Janeiro: Record, 2001. 205p.

. Sobre o nomadismo - vagabundagens pós-modernas. Rio de 1995. 250p.

. A contemplação do mundo. Porto Alegre: Artes e Ofícios Editora,

MEIHY, José Carlos Sebe B. e HOLANDA, Fabíola. História Oral - Como fazer como pensar. São Paulo: Contexto, 2007. 175p.

MELUCCI, Alberto. O JOGO DO EU - A mudança de si em uma sociedade global. Rio Grande do Sul: Editora Unisinos, 2004. 184p.

MERLEAU-PONTY, Maurice. O entrelaçamento - o quiasma. in: O visível e o invisível. São Paulo: Perspectiva, 1992.

MILAN, Betty. O Paraíso. Disponível em :

http://artenalinha.wordpress.com/2013/03/19/betty-milan-tem-instalacao-poema-na-estacaoparaiso-do-metro/, 2014.

MILLER, Sidney. A estrada e o violeiro. in: Elenco. Rio de Janeiro: Som Livre, 1967.

MORAES, Vinícius de. Solilóquio in: Poesia Completa e Prosa. Rio de Janeiro: Nova Aguilar, 1998. 1571p.

MORIN, Edgar. $O$ desenho e a intenção complexos, o esboço e o projeto complexos. In: Introdução ao pensamento complexo. Tradução de Eliane Lisboa. Porto Alegre: Sulinas, 2006. 
MUEK, Ron. Man in a Boat. 2002

Disponível em:

https://www.google.com.br/search?q=man $+\mathrm{in}+\mathrm{a}+$ boat + mueck\&source $=1 \mathrm{nms} \&$ tbm $=\mathrm{isch} \& \mathrm{sa}=$ X\&ei=3w4LVf3XFbWOsQTzzYG4Cw\&ved=0CAcQ_AUoAQ\&biw=1024\&bih=489\#imgdi $\mathrm{i}=$ \&imgrc $=$ nLT64IN6fciZ5M\%253A\%3BiqABKrW9c31MTM\%3Bhttps $\% 253 \mathrm{~A} \% 252 \mathrm{~F} \% 25$

2Fcursobasicodefotografia.files.wordpress.com $\% 252 \mathrm{~F} 2013 \% 252 \mathrm{~F} 11 \% 252 \mathrm{Fron}-$ mueck-

file_785_esp.jpg $\% 3 \mathrm{Bhttps} \% 253 \mathrm{~A} \% 252 \mathrm{~F} \% 252 \mathrm{Fcursobasicodefotografia.wordpress.com} \% 252$ F2013\%252F11\%252F14\%252Fimagenes-muestra-ron-mueck-enargentina $\% 252 \mathrm{~F} \% 3 \mathrm{~B} 1400 \% 3 \mathrm{~B} 933$

NAVIA, Luis E. Diógenes, O Cínico. São Paulo: Odysseus Editora, 2009. Tradução de João Miguel Moreira Auto. 309p.

NIETZSCHE, Friedrich Wilhelm. A Filosofia na Era Trágica dos Gregos. Tradução de Gabriel Valladão Silva. Porto Alegre: L\&PM, 2012.

Ecce Homo. Porto Alegre: L\&PM, 2013. Tradução

Marcelo Backes, 172p.

Sanctus Januarius in: A Gaia Ciência. Tradução de

Paulo César de Sousa. São Paulo: Companhia das Letras, 2011. 362p.

. O Andarilho in: Humano, demasiado humano. São

Paulo: Companhia das Letras, 2005.Tradução Paulo César de Sousa. 313p.

O nascimento da tragédia in: ECCE HOMO. Tradução

de Artur Mourão. Covilhã: Lusofonia, 2008. 111p.

NUNES, Benedito. Filosofia e Poesia. in: Hermenêutica e Poesia. Belo Horizonte: Humanitas, 2007. 181p.

NAJMANOVICH, Denise. A Linguagem dos vínculos: da independência absoluta à autonomia relativa. In: O Sujeito Encarnado. Tradução de Maria Teresa Esteban e Paulo Sgardi. Rio de Janeiro: OP \& A, 2001.

NAVARRO, Eduardo de Almeida. Nomes possuíveis e não possuíveis. Método Moderno de Tupi Antigo. São Paulo: Global, 2006, 463p.

OKUBARO, Jorge. O Súdito. São Paulo: Terceiro Nome, 2006. 542p.

PAZ, Octavio. Máscaras Mexicanas.in: Labirinto da Solidão e Post Scriptum. Rio de Janeiro: Paz e Terra, 1992. Tradução Eliane Zagury, 261p. 
PERNIOLA, Mario. O Sex appeal do inorgânico. Coimbra: Ariadne Editora, 2004. . Pensando o Ritual. São Paulo: Studio Nobel, 2000.

PESSANHA, José Américo Motta. Bachelard e Monet: O Olho e a Mão in: NOAVES, Adauto (org.). São Paulo: Companhia das Letras, 1998.

PESSOA, Fernando. Os Castellos in: Mensagem. Portugal: Babel, 2010.102p.

Letras, 1998. 274p. . Tabacaria. In: Ficções do Interlúdio. São Paulo: Companhia das

POMPEIA, Raul. $I$ in: O Ateneu. São Paulo: Ática, 1996. Disponível em: http://www.bibvirt.futuro.usp.br.

QUENTAL, Antero de. Hino à Razão in: A Literatura Portuguêsa Através de Textos. São Paulo: Cultrix, 1972. Organizador Massaud Moisés.

ROSSET, Clément. Lo Trágico es lo "Insdispensable” in: La filosofia trágica. Tradução de Ariel Dilon. Buenos Aires: El cuento de plata, 2010. 176p.

. O real e seu duplo: Ensaio sobre a Ilusão. Rio de Janeiro: José Olympio, 2008. Tradução José Thomaz Brum. 123p.

El embrujo del yo. In: Lejos de mi. Estudo sobre la identidad. S.1.: Marbot Ediciones, s.d. Tradução Lucas Vermal.

ROSA, Guimarães. A terceira margem do rio in: Primeiras Estórias. Rio de Janeiro: Nova Fronteira, 1988. 160p.

. Grande Sertão: Veredas. Rio de Janeiro: Nova Fronteira, 2001. 624p.

RUBIO, Katia. Atletas olímpicos brasileiros. São Paulo: SESI-SP - Editora, 2015. 640p.

As mulheres e o esporte olímpico brasileiro. São Paulo: Casa do Psicólogo, 2011.259p.

Um instrumento: as histórias de vida. in: Medalhistas Olímpicos brasileiros: histórias e imaginário. São Paulo: Casa do Psicólogo-FAPESP, 2006. 369p. 
. Memória e Imaginário de Atletas Medalhistas Olímpicos Brasileiros. São Paulo, 2004. (Tese de Livre Docência - Escola de Educação Física e Esporte da Universidade de São Paulo). 369p.

O Atleta e o mito do herói. São Paulo: Casa do Psicólogo, 2001. 225p.

RUBIRA, Fabiana de Pontes. Contar e ouvir estórias: um diálogo de coração para coração acordando imagens. São Paulo, 2006. (Dissertação de Mestrado Educação Departamento de Cultura, Organização e Educação da Faculdade Educação da Universidade de São Paulo). 241p.

RÜNSEN, Jörn. Experiência do tempo e auto-identidade - a origem da consciência histórica in: Razão Histórica - Teoria da história: os fundamentos da ciência histórica. Brasília: Editora da Universidade de Brasília, 2001. Tradução Estevão de Rezende Martins. 194p.

SANTOS, Boaventura de Sousa. Um Discurso sobre as Ciências. São Paulo: Cortez, 2008.

SAYAD, Abdemalek. A imigração: ou os paradoxos da alteridade. São Paulo: Edusp, 1998.

SAURA, Soraia Chung. Planeta de boieiros: culturas populares e educação de sensibilidade no imaginário do bumba-meu-boi. São Paulo, 2008 (Tese de Doutorado em Educação - Departamento de Cultura e Organização da Faculdade de Educação da Universidade de São Paulo. 475p.

SEIXAS, Peter. Ação Histórica como um Problema para Pesquisadores em Educação em História. in: Antíteses. Paraná, 2012, v.5, n.10, p. 537-553.

SILVEIRA JÚNIOR. Mesac Roberto. A travessia que mancha o corpo: imagens da imigração e a educação transitória. São Paulo, 2008 (Tese de Doutorado - Educação Departamento de Cultura, Organização e Educação da Faculdade Educação da Universidade de São Paulo). 112p.

SÓfOCLES. A Trilogia Tebana - Édipo Rei - Édipo em Colono - Antígona. Rio de Janeiro: Zahar, 1990. Tradução Mário da Gama Kury. 262p.

TAGORE, Rabindranath, Pássaros Feridos. Tradução Ivo Storniolo. São Paulo: Paulinas, 1991.

TÁVOLA, Arthur da. A alma dos diferentes in: Pensador INFO. Disponível em: http://pensador.uol.com.br/frase/MTg2NjA3/, 2012. 
TEIXEIRA, Maria Cecília Sanchez. Pedagogia do imaginário e função imaginante: redefinindo o sentido da educação. in: Palestra Proferida no II Colóquio Internacional Imaginário e Educação - UFF - Ponta Grossa, 2006.

VIEIRA, Trajano. Entre a razão e o daimon. in: Édipo Rei de Sófocles. São Paulo: Perspectiva, s.d. 112p.

VIANNA, Cláudia. Identidade e Ação Coletiva. In: OS NÓS DO "NÓS" - Crise e perspectivas da ação coletiva docente em São Paulo. São Paulo: Xamã, 1999, 214 p. 


\section{ANEXOS}

\subsection{ANEXO A}

\section{A terceira margem do rio}

NOSSO PAI era homem cumpridor, ordeiro, positivo; e sido assim desde mocinho e menino, pelo que testemunharam as diversas sensatas pessoas, quando indaguei a informação. Do que eu mesmo me alembro, ele não figurava mais estúrdio nem mais triste do que os outros, conhecidos nossos. Só quieto. Nossa mãe era quem regia, e que ralhava no diário com a gente - minha irmã, meu irmão e eu. Mas se deu que, certo dia, nosso pai mandou fazer para si uma canoa.

Era a sério. Encomendou a canoa especial, de pau de vinhático, pequena, mal com a tabuinha da popa, como para caber justo o remador. Mas teve de ser toda fabricada, escolhida forte e arqueada em rijo, própria para dever durar na água por uns vinte ou trinta anos. Nossa mãe jurou muito contra a idéia. Seria que, ele, que nessas artes não vadiava, se ia propor agora para pescarias e caçadas? Nosso pai nada não dizia. Nossa casa, no tempo, ainda era mais próxima do rio, obra de nem quarto de légua: o rio por aí se estendendo grande, fundo, calado que sempre. Largo, de não se poder ver a forma da outra beira. E esquecer não posso, do dia em que a canoa ficou pronta.

Sem alegria nem cuidado, nosso pai encalçou o chapéu e decidiu um adeus para a gente. Nem falou outras palavras, não pegou matula e trouxa, não fez a alguma recomendação. Nossa mãe, a gente achou quer ela is esbravejar, mas persistiu somente alva de pálida, mas o beiço e bramou: - "Cê vai, ocê fique, você nunca volte!" Nosso pai suspendeu a resposta. Espiou manso para mim, me acenando de vir também, por uns passos. Temi a ira de nossa mãe, mas obedeci, de vez de jeito. O rumo daquilo me animava, chega que um propósito perguntei: - "Pai, o senhor me leva junto, nessa sua canoa?" Ele só retornou o olhar em mim, e me botou a bênção, com gesto me mandando para trás. Fiz que vim, mas ainda virei, na grota do mato, para saber. Nosso pai entrou na canoa a desamarrou, pelo remar. E a canoa saiu se indo - a sombra dela por igual, feito um jacaré, comprida longa.

Nosso pai não voltou. Ele não tinha ido a nenhuma parte. Só executava a invenção de se permanecer naqueles espaços do rio, de meio a meio, sempre dentro da canoa, para dela não saltar, nunca mais. A estranheza dessa verdade deu para estarrecer de todo a gente. Aquilo que não havia, acontecia. Os parentes, vizinhos e conhecidos nossos, se reuniram, tomaram juntamente conselho.

Nossa mãe, vergonhosa, se portou com muita cordura; por isso, todos pensaram de nosso pai a razão em que não queriam falar: doideira. Só uns achavam o entanto de poder também ser pagamento de promessa; ou que, nosso pai, quem sabe, por escrúpulo de estar com alguma feia doença, que seja, a lepra, se desertava para outra sina de existir, perto e longe de sua família dele. As vozes das notícias se dando pelas certas pessoas - passadores, moradores das beiras, até do asfalto da outra banda descrevendo que nosso pai nunca se surgia a tomar terra, em ponto nem canto, de dia nem de noite, da forma como cursava o rio, solto solitariamente. Então, pois, nossa mãe e os aparentados nossos assentaram: que o mantimento que tivesse, ocultado na canoa, se gastava; e, ele, ou desembarcava e viajava s'embora, para jamais, o que ao menos se condizia mais correto, ou se arrependia, por uma vez, para casa. 
No que num engano. Eu mesmo cumpria de trazer para ele, cada dia, um tanto de comida furtada: a idéia que senti, logo na primeira noite, quando o pessoal nosso experimentou de acender fogueiras em beirada do rio, enquanto que, no alumiado delas, se rezava e se chamava. Depois, no seguinte, apareci, com rapadura, broa de pão, cacho de bananas. Enxerguei nosso pai, no enfim de uma hora tão custosa para sobrevir; só assim, ele no ao-longe, sentado no fundo da canoa, suspendida no liso do rio. Me viu, não remou para cá, não fez sinal. Mostrei o de comer, depositei num oco de pedra do barranco, a salvo de bicho mexer e a seco de chuva e orvalho. Isso, que fiz, e refiz, sempre, tempos a fora. Surpresa que mais tarde tive: que nossa mãe sabia desse meu encargo, só se encobrindo de não saber; ela mesma deixava, facilitado, sobra de coisas, para o meu conseguir. Nossa mãe muito não se demonstrava.

Mandou vir o tio nosso, irmão dela, para auxiliar na fazenda e nos negócios. Mandou vir o mestre, para nós, os meninos. Incumbiu ao padre que um dia se revestisse, em praia de margem, para esconjurar e clamar a nosso pai o dever de desistir da tristonha teima. De outra, pro arranjo dela, para medo, vieram os dois soldados. Tudo o que não valeu de nada. Nosso pai passava ao largo, avistado ou difuso, cruzando na canoa, sem deixar ninguém se chegar à pega ou à fala. Mesmo quando foi, não faz muito, dos homens do jornal, que trouxeram a lancha e tencionavam tirar retrato dele, não venceram: nosso pai se desaparecia para a outra banda, aproava a canoa no brejão, de léguas, que há, por entre os juncos e mato, e só ele conhecesse, a palmos, a escuridão daquele.

A gente teve de se acostumar com aquilo. Às penas, que, com aquilo, a gente mesmo nunca se acostumou, em si, na verdade. Tiro por mim, que, no que queria, e no que não queria, só com nosso pai me achava: assunto que jogava para trás meus pensamentos. O severo que era, de não se entender, de maneira nenhuma, como ele agüentava. De dia e de noite, com sol ou aguaceiros, calor, sereno, e nas friagens terríveis de meio-do-ano, sem arrumo, só com o chapéu velho na cabeça, por todas as semanas, e meses, e os anos - sem fazer conta do se-ir do viver. Não pojava em nenhuma das duas beiras, nem nas ilhas e croas do rio, não pisou mais em chão nem capim. Por certo, ao menos, que, para dormir seu tanto, ele fizesse amarração na canoa, em alguma ponta-de-ilha, no esconso. Mas não armava um foguinho em praia, nem dispunha de sua luz feita, nunca mais riscou um fósforo. $\mathrm{O}$ que consumia de comer, era só um quase, mesmo do que a gente depositava, no entre as raízes da gameleira, ou na lapinha de pedra do barranco, ele recolhia pouco, nem o bastável. Não adoecia? E a constante força dos braços, para ter tento na canoa, resistido, mesmo na demasia das enchentes, no subimento, aí quando no lanço da correnteza enorme do rio tudo rola o perigoso, aqueles corpos de bichos mortos e paus-de-árvore descendo - de espanto de esbarro. E nunca falou mais palavra, com pessoa alguma. Nós, também, não falávamos mais nele. Só se pensava. Não, de nosso pai não se podia ter esquecimento; e, se, por um pouco, a gente fazia que esquecia, era só para se despertar de novo, de repente, com a memória, no passo de outros sobressaltos.

Minha irmã se casou; nossa mãe não quis festa. A gente imaginava nele, quando se comia uma comida mais gostosa; assim como, no gasalhado da noite, no desamparo dessas noites de muita chuva, fria, forte, nosso pai só com a mão e uma cabaça para ir esvaziando a canoa da água do temporal. Às vezes, algum conhecido nosso achava que eu ia ficando mais parecido com nosso pai. Mas eu sabia que ele agora virara cabeludo, barbudo, de unhas grandes, mal e magro, ficado preto de sol e dos pêlos, com o aspecto de bicho, conforme quase nu, mesmo dispondo das peças de roupas que a gente de tempos em tempos fornecia.

Nem queria saber de nós; não tinha afeto? Mas, por afeto mesmo, de respeito, sempre que às vezes me louvavam, por causa de algum meu bom procedimento, eu falava: - "Foi pai que um dia me ensinou a fazer assim..."; o que não era o certo, exato: mas, que era mentira por verdade. Sendo que, se ele não se lembrava mais, nem queria saber da gente, por que, então, não subia ou descia o rio, para outras paragens, longe, no não-encontrável? Só ele soubesse. Mas minha irmã teve menino, ela mesma entestou que queria mostrar para ele o neto. Viemos, todos no barranco, foi num dia bonito, minha irmã de vestido branco, que tinha sido o do casamento, ela erguia nos braços a criancinha, o marido dela segurou, para defender os dois, o guarda-sol. A gente chamou, esperou. Nosso pai não apareceu. Minha irmã chorou, nós todos aí choramos, abraçados. 
Minha irmã se mudou, com o marido, para longe daqui. Meu irmão resolveu e se foi, para uma cidade. Os tempos mudavam, no devagar depressa dos tempos. Nossa mãe terminou indo também, de uma vez, residir com minha irmã, ela estava envelhecida. Eu fiquei aqui, de resto. Eu nunca podia querer me casar. Eu permaneci, com as bagagens da vida. Nosso pai carecia de mim, eu sei - na vagação, no rio, no ermo - sem dar razão de seu feito. Seja que, quando eu quis mesmo saber, e firme indaguei, me diz-que-disseram: que constava que nosso pai, alguma vez, tivesse revelado a explicação, ao homem que para ele aprontara a canoa. Mas, agora, esse homem já tinha morrido, ninguém soubesse, fizesse recordação, de nada mais. Só as falsas conversas, sem senso, como por ocasião, no começo, na vinda das primeiras cheias do rio, com chuvas que não estiavam, todos temeram o fim-do-mundo, diziam: que nosso pai fosse o avisado que nem Noé, que, por tanto, a canoa ele tinha antecipado; pois agora me entrelembro. Meu pai, eu não podia malsinar. E apontavam já em mim uns primeiros cabelos brancos.

Sou homem de tristes palavras. De que era que eu tinha tanta, tanta culpa? Se o meu pai, sempre fazendo ausência: e o rio-rio-rio, o rio - pondo perpétuo. Eu sofria já o começo de velhice - esta vida era só demoramento. Eu mesmo tinha achaques, ânsias, cá de baixo, cansaços, perenguice de reumatismo. E ele? Por quê? Devia de padecer demais. De tão idoso, não ia, mais dia menos dia, fraquejar do vigor, deixar que a canoa emborcasse, ou que bubuiassem sem pulso, na levada do rio, para se despenhar horas abaixo, em tororoma e no tombo da cachoeira, brava, com o fervimento e morte. Apertava o coração. Ele estava lá, sem a minha tranqüilidade. Sou o culpado do que nem sei, dor em aberto, no meu foro. Soubesse - se as coisas fossem outras. E fui tomando idéia.

Sem fazer véspera. Sou doido? Não. Na nossa casa, a palavra doido não se falava, nunca mais se falou, os anos todos, não se condenava ninguém de doido. Ninguém é doido. Ou, então, todos. Só fiz, que fui lá. Com um lenço, para o aceno ser mais. Eu estava muito no meu sentido. Esperei. Ao, por fim, ele apareceu, aí e lá, o vulto. Estava ali, sentado à popa. Estava ali, de grito. Chamei, umas quantas vezes. E falei, o que me urgia, jurado e declarado, tive que reforçar a voz: - "Pai, o senhor está velho, já fez o seu tanto ... Agora, o senhor vem, não carece mais ... O senhor vem, e eu, agora mesmo, quando que seja, a ambas vontades, eu tomo o seu lugar, do senhor, na canoa!...” E, assim dizendo, meu coração bateu no compasso mais certo.

Ele me escutou. Ficou de pé. Manejou remo n'água, proava para cá, concordando. E eu tremi, profundo, de repente: porque, antes, ele tinha levantado o braço e feito um saudar de gesto - o primeiro, depois de tamanhos anos decorridos! E eu não podia... Por favor, arrepiados os cabelos, corri, fugi, me tirei de lá, num procedimento desatinado. Porquanto que ele me pareceu vir: da parte de além. E estou pedindo, pedindo, pedindo um perdão.

Sofri o grave frio dos medos, adoeci. Sei que ninguém soube mais dele. Sou homem, depois desse falimento? Sou o que não foi, o que vai ficar calado. Sei que agora é tarde, e temo abreviar com a vida, nos rasos do mundo. Mas, então, ao menos que, no artigo da morte, peguem em mim, e me depositem também uma canoinha de nada, nessa água que não pára, de longas beiras: e, eu, rio abaixo, rio a fora, rio a dentro - o rio. 


\subsection{ANEXO B - TERMO DE CONSENTIMENTO}

Concordo em participar, como voluntário/a, da pesquisa intitulada ASPECTOS DA FORMAÇÃO DA IDENTIDAdE DO MIGRANTE: PEDAGOGIA DA ESCOLHA, IMAGINÁRIO E SOCIEDADE.

O pesquisador responsável é ANTÔNIO ROBERTO GIRALDES, aluno da Faculdade de Educação da Universidade de São Paulo, orientado pela PROFESSORA DOUTORA KATIA RUBIO, os quais podem ser contatados pelo e-mail argiraldes@gmail.com ou telefone XXXXXXXXXX.

O objetivo da pesquisa é estabelecer uma discussão sobre as formas pelas quais o caminho da história dos migrantes pode ser contemplado, relacionando-o com as maneiras que as instituições brasileiras os atendem e como eles se utilizam das experiências para recriarem seus sentidos no mundo e, consequentemente, suas identidades.

Minha participação consistirá relatar minha história de vida.

Compreendo que esse estudo possui finalidade de pesquisa e que os dados obtidos serão divulgados seguindo as diretrizes éticas da pesquisa, assegurando, assim, minha privacidade.

Sei que posso retirar meu consentimento quando eu quiser e que não receberei nenhum pagamento por essa participação.

Nome e Assinatura

Local e data. 


\subsection{ANEXO C}

\section{PRIMEIRA HISTÓRIA}

ENTREVISTADOR - Com quantos anos o Senhor veio...?

ENTREVISTADO - Eu veio no Brasil com 19 anos, foi em 1959, em janeiro de 59, de 19 para 20 anos ... acontece ... eu veio da Itália, para anotar aqui, porque eu fui refugiado antigo sistema de Iugoslávia, aí eu fiquei na Itália, um ano e meio, aí veio a imigração, tava esperando a imigração para vir Canadá, Austrália, como era solteiro ... eles usava mais pessoal casado ...

ENTREVISTADOR - Mas, quando o Senhor nasceu, já era Iugoslávia?

ENTREVISTADO - Já é ...

ENTREVISTADOR - Já era regime ... porque a Revolução Russa ...

ENTREVISTADO - A Antiga Iugoslávia não tem nada com a Revolução Russa, só tem comunismo 45 quando foi derrubado o regime ...

ENTREVISTADOR - A segunda guerra...

ENTREVISTADO - Não eu não veio na guerra porque eu nem estava na guerra, quando guerra terminou eu tinha 7 anos aí eu fez escola lá na antiga Iugoslávia, porque lá é seguinte são 6 repúblicas que formavam antiga Iugoslávia, mas cada uma tinha sua nacionalidade.

ENTREVISTADOR - E língua diferente também.

ENTREVISTADO - Não, praticamente a Macedônia só era diferente, mas a Montenegro e Bósnia, Servo e Croata são praticamente semelhante, diferença é letras, eles escreve em cirílica são sérvios, nós que escrevem em romano, que é latim. 1957, mês junho, dia 19 de junho eu fugi de antigo sistema, foi convocado para servir o exército 3 anos da marinha da antiga Iugoslávia ... e eu não quis ... aí eu fugi para a Itália ...

ENTREVISTADOR - E por que que o Senhor fugiu?

ENTREVISTADO - É !!!! Eu era jovem queria procurar vidas melhores, oportunidades melhores, saí que todos os jovens hoje quer sair, acha sempre no outro lugar é melhor que onde nasceu, comunismo, perseguições e essas coisas...

ENTREVISTADOR - Lá não tava bom, então.

ENTREVISTADO - Não tava bom, era difícil a pessoa fugia, eles pegavam a pessoa se pegava na fronteira ia ser preso e devolvia e eu teve sorte que não me prenderam...

ENTREVISTADOR - Ah! o Senhor teve coragem para fugir ... O Senhor ficou com medo na hora de fugir?

ENTREVISTADO - Não, eu fugi da fronteira, chama Koper, atual Eslovênia, Eslovênia, fronteira de Trieste a Trieste de Koper .... saí de capital da Croácia que é Zagreb, que é onde fez o curso de escola técnica, técnica de sapateiro, lá é profissional, tudo profissional tem que na escola 3 anos para aprender em escola de sapato, essas coisas, de couro, fabricação, eu fiz esse curso ... e quando cheguei na Itália, foi lá ... me tiraram minha carteira de identidade de meu antigo país Iugoslávia fiquei 30 dias em Trieste, Trieste é que faz fronteira... 
ENTREVISTADOR - Mas a Itália recebeu o Senhor tranquilamente...

ENTREVISTADO - Recebeu tranquilo ... É !!!! Recebeu não só eu como vários imigrantes foram fugindo do leste europeu, tinha um Bósnios. Búlgaros, Romenos, tinha tudo povo do leste europeu, Polonês que fugiram...

ENTREVISTADOR - O Senhor fugiu sozinho ou ...

ENTREVISTADO - Eu fugi com mais dois colegas, depois não mais deles se eles foram devolvidos para Iugoslávia ou ficaram fora...

ENTREVISTADOR - E seus pais. O Senhor falou assim para os seus pais: - Eu vou fugir.

ENTREVISTADO - Eu não falei para os pais, eu falei para o meu tio, lá, que faleceu agora esses dias ... aí, falei que ia fugir tudo não deu ... pra ... naquela época todo jovem queria fugir tudo do comunismo e pelo mundo ... liberdade ... entendeu ... vida melhor ... vida melhor ... aí depois de Trieste, fiquei três meses em Trieste, aí foi transferido para centro da Itália, Cremona, Lombardia, perto de Milano, aí eu fiquei três meses lá, norte da Itália, aí depois veio gripe asiática no país, mudar para sul da Itália era para ir para o não podia ir porque era migração para a Austrália ou Canadá, aí eu foi transferido para Nápoli...

ENTREVISTADOR - Mas o senhor ficava numa estalagem de imigrantes na Itália...

ENTREVISTADO - Chama campo de refugiados imigrantes ...

ENTREVISTADOR - Entendi ...

ENTREVISTADO - Era uma casa né que você não ta confinado, você pode sair onde quiser, ela recolhia imigrantes e você podia sair onde quiser ... sempre foi livre, recebe documentos na Itália de passagem como se estrangeiro, mas pode ir onde quiser, não é que você tava preso, você não tava preso que muita gente confunde campo de refugiados e campo de concentração, não tem nada uma coisa da outra entendeu ...

ENTREVISTADOR - Entendi $\ldots$

ENTREVISTADO - Aí eu foi transferido para Nápoli, de Nápoli para Bersa, 15 quilômetros, de Nápoli, fiquei mais um ano lá, aí era pra eu migrar para a Suécia, nunca deu resposta, aí eles pediram se quiserem viajar para a África, naquela época era escravidão dos negros e brancos ingleses eu rejeitei não quis ir para África, não me interessei lá nas minas...

ENTREVISTADOR - Por causa $\ldots$

ENTREVISTADO - É !!! Porque eu ... não quero servir exército para matar ninguém ... então não fui para Johanesburgo... e lá minas de ouro ... pelo menos eles fazia filme na época 58 anos atrás certo? Aí depois chamaram para a Alemanha também trabalhar nas minas de carvão eu também não aceitei, aí veio a chamada para o Brasil e eu aceitei pra vir para o Brasil foi registrado como imigrante definitivo no consulado brasileiro tenho documento, tenho registro tudo em 1958, mais ou menos em novembro, em novembro, outubro, aí partir no véspera do ano, véspera do ano que saí de Nápoli, via Barcelona, Lisboa para Rio de Janeiro ...

ENTREVISTADOR - E como é que foi chegar aqui no Rio de Janeiro?

ENTREVISTADO - Aí quando chegar no Rio ... a autoridade ... naquela época já sabia quando vinha imigrante permanente, aí polícia federal esperou gente, sabia que era o consulado brasileiro aí levaram nós para a Ilha das Flores com nove italianos, eu cheguei junto com nove italianos ... 
ENTREVISTADOR - Ilha das flores ...

ENTREVISTADO - Ilha das flores ... não sei se conhece Niterói ... aí eu foi lá numa ilha, longe do mar, mais ou menos 500 metros só podia sai com barco ... chama Ilha das Flores, mas não tinha nada de flores, só pernilongo, fica mordido de pernilongo ...

ENTREVISTADOR - E o Senhor fazia o que lá? Na Ilha das Flores?

ENTREVISTADO - Aí você, como imigrante, tem que esperar receber carteira profissional, carteira de identidade, na época, estrangeiro tem tudo mesmo direito igual você daqui mesma coisa, só que tem que ter documento para trabalhar, quando eu recebi documento no Rio... aí a organização que trouxe nós para o Brasil, foi na Rua da Glória, na Rua da Glória centro velho do Rio... eu fiquei, aí recebi documentos e fiquei sentado no parque Copacabana, tomando coca-cola, era barata na época, acho que era 50 centavos.

ENTREVISTADOR - E do dinheiro que o Senhor conseguiu o Senhor trouxe de lá da Croácia.

ENTREVISTADO - Não ... não trouxe né lá nem agora né lá ... eu cheguei sem dinheiro e continuo sem dinheiro (risos) ... gostou né? ... aí a organização me deu na época 200 cruzeiros ... uma organização Católica que trouxe gente para cá, falaram que nossa migração era maior em São Paulo, eles ma falaram no Rio aí eu vem para São Paulo ...

ENTREVISTADOR - Aí o senhor gostou de ficar sentado tomando coca-cola lá em Copacabana.

ENTREVISTADO - É !!!! Ninguém mexia comigo eu lá sentado no Rio de Janeiro, pena Rio era uma beleza ... a cidade mais bonita do mundo eu como criança sonhava ver Rio de Janeiro o Brasil jogou 1950 com o Uruguai perdeu eu tinha 12 doze anos eu recebi jornal, nunca ia imaginar ver um dia Rio de Janeiro, depois de 9 anos eu ia pra cá, no Brasil fala assim, 250 mil pessoas chorando que perdeu eu tava lendo no vilarejo onde eu nasci ...

ENTREVISTADOR - Então quando o Senhor chegou em Copacabana o Senhor se lembrou de quando ...

ENTREVISTADO - Aí eu lembrei ... eu já sabia do Rio de Janeiro ... lembrava tudo ... Eu fiquei no Rio 30 dias depois eu vim para São Paulo ... de lá depois não saí mais de São Paulo, to aqui a 50 anos...

ENTREVISTADOR - O Senhor foi para a estalagem de migrantes de São Paulo.

ENTREVISTADO - De São Paulo ... lá no Brás, Rua Visconde de Parnaíba não sei se você conhece ...Museu dos imigrantes onde recebia não só nós como recebia Russos, que fugia da China, a China não matou ninguém também a China mandou eles embora da China... Os Russos que fugiram do imperador do comunismo foram para a China depois veio o comunismo na China foi obrigado a fugir de novo, o ser humano é assim então, vieram para o Brasil, tinha russos, tinha Italianos, tinha Polonês, tudo que vinha para o Brasil, não ficava na rua jogado, ia para a casa dos imigrantes e depois encaminhava para ir trabalhar...

ENTREVISTADOR - Me diz uma coisa, o Senhor saiu então da Iugoslávia. O Senhor se considerava Iugoslavo ou Croata?

ENTREVISTADO - Eu sempre me considerei Croata.

ENTREVISTADOR - Mesmo o país sendo ... 
ENTREVISTADO - É !Mesmo o país ... eu tenho até documento da da antiga Iugoslávia mas eu fala que eu sou Croata meus país são Croatas porque lá é diferente do que diz no Brasil, no Brasil diz quem nasce no Brasil é tudo brasileiro não é isso? No leste europeu não é assim, que teu pai, teu avô bisavô, você pertence a isso aí, por isso tem essas briga, essas confusões lá, entendeu? , porque você nasce na Croácia, 400 anos, mas você pode continuar sendo Sérvio, você entendeu, a mesma coisa se você nascer no Brasil, negros são africanos, africanos é brasileiro não é isso? Nas Américas é assim, na América toda é assim... eu me considerava Croata lá, eu vim para cá para São Paulo...me deram documento Croata, tinha manifestações pela Croácia contra a Iugoslávia.

ENTREVISTADOR - Isso mais ou menos em 1960...

ENTREVISTADO - $60 \operatorname{sim}$.... até 90 até é interessante em São Paulo comunidades polonesa, búlgara, tcheca, Croata, hoje você não acha mais ninguém em São Paulo, as pessoas vão envelhecendo e não se preocupa mais com esses problemas sabe ... nós ia na praça da Sé com bandeiras, manifestando contra regime de comunismo, mas nunca teve dificuldade no Brasil, sempre trabalhei...

ENTREVISTADOR - Mas aí o primeiro emprego que o Senhor teve no Brasil qual foi?

ENTREVISTADO - Meu emprego, eu sou sapateiro de profissão ... trabalhei na rua....

ENTREVISTADOR - Aí o Senhor alugou uma casa ... porque começou a trabalhar não podia ficar mais na estalagem...

ENTREVISTADO - Não aí eu instalei aqui pertinho ... próximo daqui ... consertava sapato ... morava como solteiro ... aí depois casei, depois veio filho, dinheiro era curto aí larguei sapataria, era para viajar para o Canadá, demorou papelada anos $70 \ldots$

ENTREVISTADOR - Mas por que que o Senhor queria ir para o Canadá?

ENTREVISTADO - Minha irmão morava lá ... meu cunhado falou olha ... e ela foi lá da Croácia e me chamou lá mas demorou visto essa coisa ... e prá que que ia procurar país com frio, não conheço idioma ia sair daqui para quê?

ENTREVISTADOR - E prá falar português foi difícil?

ENTREVISTADO - Quando eu cheguei aqui eu já entendia italiano, porque eu vivi na Itália ... trabalhei num restaurante de comida italiana ... trabalhar na cozinha porque tinha o que comer né? Lavar prato ... essas coisas (risos) você acha interessante né...

ENTREVISTADOR - Meu avô, ele foi aprendiz de barbeiro, o primeiro emprego dele...

ENTREVISTADO - Eu sapateiro, mas não só sapateiro sou, formado como técnico em sapateiro ... trabalhar aprender ofício sabe ... trabalhar, esse exercício... eu trabalhei anos em sapato depois trabalhei em indústria de tinta em São Bernardo de Suvinil quartzolit, fazia cobrança conheço em São Paulo tudo o que você quiser depois trabalhei do cobrança conheço tudo os município aqui na volta ... andava 200 quilômetros todos os dias ... não era esse tráfego que tem hoje ...por isso eu conheço São Paulo 55 anos que eu moro aqui você entendeu ...

ENTREVISTADOR - E quando o Senhor chegou aqui, começou a trabalhar aqui em São Paulo... o Senhor sentia saudade da Croácia?

ENTREVISTADO - A gente até hoje tem saudade e sempre sonhava um dia voltar para a Croácia livre e morrer lá ... 
ENTREVISTADOR - Por exemplo, o Senhor tava aqui no Brasil aí o Senhor ia para as passeatas não é isso?

ENTREVISTADO - É só que eu não foi passear lá 33 anos...

ENTREVISTADOR - Mas vamos supor que acontecesse da Iugoslávia acabar e a Croácia voltar..

ENTREVISTADO - Aí eu voltava ... Quando a Iugoslávia acabou eu voltei lá ... 90 voltei lá...

ENTREVISTADOR - Assim que a Iugoslávia acabou o Senhor voltou para lá.

ENTREVISTADO - Mas eu voltei como cidadão brasileiro ...porque antes de ter cidadania Croata eu já era brasileiro.

ENTREVISTADOR - Quantos anos o Senhor tinha quando o Senhor voltou para lá?

ENTREVISTADO - $60 \ldots$

ENTREVISTADOR - 60 ... Se isso fosse com 30 anos o Senhor voltaria a trabalharia por lá. Agora com 60.

ENTREVISTADO - Agora com 76 eu não pensa mais nisso ... pensar todo mundo pensa onde nasceu pra voltar e ficar lá você vê todo mundo falar voltar onde nasceu porque fala que o melhor lugar é onde nasceu...você não vê a gente ...

ENTREVISTADOR - Então lá é melhor que aqui?

ENTREVISTADO - Sim, eu não sei se é melhor, minha filha vive lá, e ela ta lá e não se adapta aqui também ta lá a 23 anos ...

ENTREVISTADOR - A sua filha nasceu aqui em São Paulo e ta tentando lá.

ENTREVISTADO - Ela ta lá a 23 anos e gosta.

ENTREVISTADOR - Gosta

ENTREVISTADO - Gosta, a mesma coisa, eu não me adaptei à vida de São Paulo, se você me manda qualquer lugar do Brasil eu não sei se eu ia, eu ia 15 dias mais morar não... 


\subsection{ANEXO D}

\section{SEGUNDA HISTÓRIA}

ENTREVISTADOR - Primeira frase.....

ENTREVISTADO - Eu sou músico ... desde pequeno ... desde os seis anos de idade ... aos nove anos tocando acordeon ... aos onze fiz um aperfeiçoamento e aos doze era concertista... entendeu? Em Porto Alegre até os vinte anos ... fiz um autoexílio no Chile ... lá fiz música ... fui lá para fazer economia... saí da economia ... fui lá realizar um grande sonho que era morar em Paris ... fui para Paris ... morei oito anos em Paris ... tava lá em maio de 68 ... fui existencialista ... estudei na Sourbonne ... vim para Porto Alegre ... fiquei quinze anos ... saí ... vivi dois anos em Florianópolis ... saí ... fui morar um ano em Porto Velho ... dois anos em Brasília e aí, depois, eu vim para São Paulo ... antes dois anos em Brasília... dois anos e meio em Cuiabá e agora em São Paulo ... é isso aí

(risos de todos)

ENTREVISTADOR - Dá vontade de fazer um mapinha rs ... só para eu entender começou em Porto Alegre... Porto Alegre foi para o Chile...

ENTREVISTADO - Paris... Porto Alegre ... Florianópolis ... Porto Velho ... Brasília ... Cuiabá ... Mato Grosso ... São Paulo...

ENTREVISTADOR - E morou um tempo em cada lugar desses...

ENTREVISTADO -

"Escreva aí no seu caderno essas memórias

De uma geração que contemplou no tempo que passou, passou, as vossas glórias

Escreva aí a moda de 71, escreva aí a moda de 71

Fita no cabelo, filho nas costas, pé na estrada

Na Holanda, na Turquia, Londres, Bahia

Ou Enseada (ou Encruzilhada)

Escreva aí que tentamos morar juntos

Escreva aí que chegamos a viver juntos

Lavrando e semeando o mesmo chão

Fazendo e comendo o mesmo pão

E a fome foi maior do que a vontade de mastigar cada pedaço

Escreva aí que Deus ainda não foi achado

E houve quem correu e quem ficou sentado

Nessa nova era

Que falou desse novo homem

O tempo que passou, o fumo que queimou e ardeu nos olhos

De quem sonhou amar"

ENTREVISTADOR - Que lindo!!!

ENTREVISTADO - Essa é do Carlinhos Hartlieb... foi meu colega.... Isso tudo fiz isso sem dinheiro ... pé na estrada ... no peito e na raça

ENTREVISTADOR - O primeiro pé na estrada foi com vinte anos ... foi pro Chile ...Foi por quê?

ENTREVISTADO - Médici, eu tava no primeiro ano de faculdade de economia ... fui criado em colégio de padre de esquerda ... e você já fica com uma consciência política muito clara - solidarismo cristão ... fui prá faculdade 
ENTREVISTADOR - Teologia da libertação?

ENTREVISTADO - É ... exatamente ... eu fui ...

ENTREVISTADOR - Aí, o Senhor chegou para o seu pai e falou: Eu vou para o Chile....?

ENTREVISTADO - O pessoal tinha ido e conseguiu bolsa ... então fui para Santiago ... e disseram vai para concepção... concepção é bom lá porque não tem muito brasileiro ... é mais fácil ... e aí eu me mandei ... eu e mais dois .. conseguimos casa e alimentação no campus...

ENTREVISTADOR - Você e o seu colega ... pegaram o ônibus ...bateram na faculdade...

ENTREVISTADO - Pedimos bolsa ... Morávamos nas cabanas no campus e comíamos no restaurante $\cdots$

ENTREVISTADOR - E aí você terminou a faculdade?

ENTREVISTADO - Lá tinha os jogos estudantis tu chega lá na faculdade e tu tem vários... o pessoal lá fazia jogos... fazia programas culturais e eu fiz o hino do time do pessoal de letras (cantarola o hino) .... e a cidade , num belo dia tocou a marcha ... então de dia tinha ensaio ... tocava no final de semana para ter um pouco de dinheiro ... mas estudava um pouco né ... conheci o movimento revolucionário ... e aí um amigo meu desistiu, voltou para São Paulo e outro foi estudar Filosofia ... e eu fui para Paris que era meu grande sonho ...

ENTREVISTADOR - Mas você não chegou a se formar então ...

ENTREVISTADO - Aí eu cheguei em Porto Alegre, pedi uma passagem ...

ENTREVISTADOR - E Paris era o seu grande sonho por quê?

ENTREVISTADO - Porque tinha uma coisa que no terceiro ano ginasial em casa acho que depois de minha aula de Francês ... eu disse mãe vai ter um dia que eu vou para Paris ... devia ter treze anos ... fiquei lá de 66 a $74 \ldots$

ENTREVISTADOR - E como é que foi lá em Paris? Chegou ...

ENTREVISTADO - Cheguei lá para encontrar o existencialismo ... Simone de Beauvoir e Jean Paul Sartre ... uma vez eu os vi um mês depois ... que eles iam duas vezes por semana e ali eles almoçavam ... cheguei lá e fiquei babando para eles ... casal maravilhoso ... e eu fui para estudar música ... eu conheci um estudante lá, que me apresentou para um maestro de setenta anos, ele deu aula para o maior representante da escola dodecafônica serialista....

ENTREVISTADOR - Esses serialistas começaram em 1900 e pouquinho né?

ENTREVISTADO - É a escola do pós-guerra ... e uma vez por semana ele reunia uns alunos e alguns amigos e dava uma palestra musical ... eu fui levado para uma dessas palestras e eu pedi uma bolsa e ele me adotou ... durante seis meses eu estudei composição e harmonia com ele e composição e análise com o assistente dele e aí eu fui vivendo em Paris, a partir daí comecei a tocar guitarra na noite pra fazer dinheiro

ENTREVISTADOR - Esse tipo de música é mais clássica né? Mais ...

ENTREVISTADO - Erudita ...

ENTREVISTADOR - Precisa de disciplina... 
ENTREVISTADO - Me deram uma bolsa, fiquei com casa, com comida e eu fui estudando... e paralelamente eu não estudava totalmente para ganhar dinheiro montei um grupo ... cheguei lá, eu conheci um exilado angolano ... da época em que Angola era colônia, eles tinham um grupo, era um grupo de terceiro mundo que era composto de um venezuelano pintor, um sanitarista chileno,um exilado angolano e eu era um brasileiro e a gente tocava em bares depois das reuniões do partido comunista...

ENTREVISTADOR - E 1968...

ENTREVISTADO - A gente tinha pensado que tava fazendo a revolução socialista lá...sinceramente, que o socialismo tinha chegado... uma loucura né... uma piração ... tomaram conta das faculdades e dos prédios do governo e manifestação e assembleias dos estudantes ... dos trabalhadores e queriam tirar o De Gaulle meu ... aí ele veio ... isso é uma esculhambação e tocaram camburão lá ... mas foi maravilhoso ... era um tempo de muita experimentação tanto é que depois eu montei um grupo experimental de arte à brasileira, que tocava a história luso-afro-brasileira...África, Angola, Moçambique, Cabo Verde, Brasil, Salvador, Rio e Portugal né e a gente tinha uma história, a gente montou uma peça, em três meses fizemos um laboratório com um pessoal refugiado do Haiti, que morava lá em Nova Iorque, aí fizemos um show com a comunidade, ONGs ... Aí depois, a gente como era estudante começou a tocar no meio... Paris é uma província, uma grande província ... e a gente transitava nesse meio né? A gente era músico da corte né .. daí conheci a Brigite Bardot O que que é o dia a dia de um burguês internacional cultural ... vai para um hotel, acorda às onze da manhã ... de ressaca aí pega o carro e já vai para a praia aí come numa tendinha na beira da praia ... fica lá ... conversando ... bebendo bem até as três horas da tarde, com os filhos, com os amigos, iam para casa, trocavam e roupa e iam para o cais do porto, sete horas, oito horas, tomavam um banho e iam para um jantar, todos os dias, um jantar, vinho, uísque, era sempre assim, os garçons e a festa era sempre assim, chegavam, comia, bebia, ficava meia hora e ia embora e iam para o bar, boate e aí ia dar onze horas, na boate, ficavam lá, na boate, e iam depois em uma festa, a festinha eram os bacanais, com as gatinhas, aí ficavam bebendo, era festa, bacanal, até às cinco da manhã ... aí voltava para casa, acordava às onze ...

ENTREVISTADOR - E lá ia ...

ENTREVISTADO - Como a gente tocava nessa festa, era músico da corte ... eu eu convivi muito com esse povo todo, da arte, da música, do cinema de Paris ... e depois eu fui estudando musicologia na Sourbonne eu fiz uma tese e aí eu comecei a entrar no mundo afro brasileiro...

ENTREVISTADOR - Mas você se formou em que?

ENTREVISTADO - Na verdade, eu não terminei minha tese ...

ENTREVISTADOR - Mas pra fazer a tese tinha que ter uma graduação ou não?

ENTREVISTADO - Não ... eu fiz uma monografia e entrei diretamente em etnomúsica ... e aí eu tive uma filha e vim para Porto Alegre para tratamento dela, pois ela era doente... e eu deixei tudo lá ... apartamento ... piano .. tese ...

ENTREVISTADOR - E como é que ficou? Por que, na verdade, uma parte de você ficou lá.

ENTREVISTADO - É que eu tinha conseguido aquilo que eu queria na verdade ... eu fui para estudar ... eu fui para fazer uma tese ... mas eu vi que o sistema de pós-graduação francês era muito colonialista ... eu comecei a fazer uma tese africana e ela puxou para Portugal ... uma velhinha ... tinha setenta anos ... ela queria que fosse estudar Portugal e aí eu fiquei puto ... foi bem bem na rebeldia ... eu falei que eu não queria fazer de Portugal e então ela falou para eu escrever 30 páginas ... fui lá .. quebrei a cabeça e escrevi 30 páginas em alto francês ... e entreguei aí ela começou a ler e começou a 
ficar vermelha, nunca me esqueço .. aí ela chegou assim ... tá ... você pode fazer, você pode continuar ... com raiva mesmo ... e aí eu peguei as folhas e me mandei ...

ENTREVISTADOR - Era sobre o candomblé....

ENTREVISTADO - É do candomblé ... na verdade ... eu não queria tá na instituição ,... eu não queria estar lá ...

ENTREVISTADOR - a tua vitória foi ela dizer : pode continuar....

ENTREVISTADO - pode continuar ... rs eu como terceiro mundista eu consegui uma luta né .... independência ... liberdade né ...

ENTREVISTADOR - E de lá ? de lá você foi ...

ENTREVISTADO - Porto Alegre ... cuidar da minha filha aí eu já tava a fim de voltar para o Brasil, tinha encerrado lá ...

ENTREVISTADOR - já tinha adquirido o conhecimento ...

ENTREVISTADO - já ...Eu aí em Porto Alegre eu tive um teatro alternativo, fiz cooperativa de música ... tudo em Porto Alegre ... aí quando eu saí de Porto Alegre, eu já tinha conhecido a música indígena ... em Paris...

ENTREVISTADOR - Em Paris você conheceu música indígena?

ENTREVISTADO - Dentre outras coisas tinha música do XINGU, eu conheci.... aí então eu virei um especialista, aí eu comecei devagarinho a pesquisar ... pesquisar ... pesquisar ... aí eu fui duas vezes em aldeia fazer um trabalho multimídia de CD duplo fiz trilhas e aí convidei gente para harmonizar e tocar com o financiamento de umas ONG's japonesas ... porque houve um link com uma ONG do Japão, ganhou até prêmio....

ENTREVISTADOR - E Rondônia?

ENTREVISTADO - Foi um projeto da minha mulher ... acompanhar a minha mulher e conhecer ... e hoje eu tenho uma proposta de uma teoria da música indígena...

ENTREVISTADOR - E por que que os índios te fascinam tanto?

ENTREVISTADO - Na verdade, eu tenho uma coisa dentro de mim e essa busca acho que até é da minha geração sabe da formação do homem brasileiro ... entendeu ... que tem a ver com Anita Malfati ... desse Brasil dependente ... colonizado ... me fascina essa trilogia e eu vi que nessa trilogia o índio não entrou como tese nós somos brancos, índios e africanos, mas o índio não entrou como formação não entrou na universidade a análise que a gente tem é completamente europeia .... gente tem uma categorização do índio completamente deturpada né ... linguagem do colonizador ... do dominador ....

ENTREVISTADOR - E como é que o cenário musical de hoje te considera ou te classifica em relação a esse tipo de trabalho?

ENTREVISTADO - Não tem no Brasil hoje, dentro do Brasil quem faz música indígena ... são pouquíssimas pessoas ... há alguns que fazem leituras mas não criam em si o que a gente ta procurando é fazer, dentro dessa estética fazer uma música ... a maior parte dos brasileiros tem por aí antepassados indígenas mas não sabem nada dos índios ... eu faço parte de uma nova geração que procura estar ligada com o índio ... tem já artistas que já vêem essa cultura num plano de alta cultura ... a música 
indígena é incrível, ela é especial, dentro da música antiga no mundo ela tem uma estética sobretudo brasileira ... uma coisa muito complexa é uma música diversa ela tem formas que a música erudita ou qualquer outra música não têm e atende outro valores ...

ENTREVISTADOR - Você analisa, por exemplo, o compasso da música indígena, a partir de uma partitura ocidental?

ENTREVISTADO - A gente tende a simplificar ... a gente escuta música indígena de um jeito muito simples ... falta cultura.... falta contexto... eles têm uma visão de universo filosófica ... tem gênese ... têm filosofia ... tem medicina ... tem anticoncepcional ... tem umas ervas lá ... eles tem um experimentalismo que o civilizado não tem ... uma vez viajamos quatro horas de barco ... dois barcos ... muito longe ... chegamos lá ... as mulheres estavam de vestidos os homens estavam nus... botamos as redes ... fomos dormir ... no dia seguinte eu acordei ... e lá tem vários tipos de índios tudo misturado e quando eu acordei ... parecia que eu tava no meio da praça da sé ... tinha índio parecido até com gaúcho lá ... entendeu...

ENTREVISTADOR - Dentro da aldeia ...você viu vários...

ENTREVISTADO - ... tipos de gente que se vê no Brasil, é o povo brasileiro. 


\subsection{ANEXO E}

\section{TERCEIRA HISTÓRIA}

Olho para os seus braços e pernas esparramados na cama, enquanto você dorme com muita surpresa: já não são pequenos como foram um dia. Você cresce, Morena, agita-se tão rápido que me deixa tonta, encantada, hoje e sempre, já sei. Quando iniciei a pesquisa de fato, você andava aos solavancos. Agora tudo me espanta: o tamanho de seus pés, das roupas que usa, dos argumentos que tem. [...] Conto o pedaço dessa tua história, o pedaço que eu sei. Para que você saiba um pouco mais, e não viva sem passado, porque todos nós precisamos dele.

Meu avô ainda jovem será que sonhou um dia com estas bisnetas tão lindas do outro lado do mundo?[...] Que pensava ele quando, determinado a estudar, arrumou suas malas para viver por conta na própria China? [...] Vovô tinha um valor inestimável nos estudos, por isso foi morar na Manchúria, em uma cidade que o deixou boquiaberto porque era um refúgio dos czares russos, repleta de palácios de ouro. Sempre me surpreendeu que falasse tantas línguas, meu nome em coreano, em japonês, russo, chinês e também português. Não só falado como escrito.[...]

Em um de seus retornos à Coreia, seu avô encontrou sua bisavó.[..] Viveram os primeiros anos ainda na China. Eles eram como somos hoje: sempre prontos a ajudar qualquer pessoa.[...] Tia Young nasceu quando retornaram à Coreia. Tinha uma personalidade marcante e andarilha, herança de uma infância saltando de uma cidade para outra.[...]

Nessa época, a Coreia estava no pós-guerra na segunda guerra mundial. Apesar da devastação o domínio não seria mais dos japoneses, e isso enchia o coração das pessoas de esperança. Estados unidos e União Soviética dividiram o seu território ao meio, o que não fez muito sentido para a população local, mas enfim, se queriam chamar uma do Norte e outra do Sul, qual seria mesmo a diferença? Viveriam pacificamente como sempre, sob um governo capitalista e outro comunista - pior do que os japoneses não poderia ser, imaginavam. Foi nessa época que meus avós e Tia Young se mudaram para a Coreia do Sul por conta das afinidades do vovô com a democracia. [...]

Vovô, como todo mundo nesta época, engajou-se nas forças armadas. Como havia estudado, ocupou um alto posto no batalhão de engenharia do exército sul-coreano, estrategista e editor de mapas militares. Assim é que nunca foi combatente. Sua avó Mi Hee, a segunda filha, nasceu um pouco antes da guerra efetivamente "estourar", como dizem.[...]

A Coreia do Norte invadia a Coreia do Sul, empurrando todos para a ponta do arquipélago. Assim é que os próximos filhos nasceram nesse trânsito. Tio Won nasceu entre Seoul e Pusan, em plena guerra.[...]

A Tia Sun nasceu bem ao Sul em Pusan, e foi mesmo um ano inesquecível: 15 de julho de 1953, apenas 12 dias antes de ser assinado pelos exércitos coreanos o acordo de Armistício Militar para trazer paz à nação.[...]

Tia Myung já nasceu quando todos estavam de volta e em paz em Seoul. É a mais nova e seu nascimento foi deflagrador da imigração dos meus avós com seus cinco filhos. Por isso ela traz o gene da mudança com ela: viajou o mundo todo, enchendo as sobrinhas dos presentes mais divertidos e diferentes, é totalmente moderna e atual, cheia de inovações e defensora ferrenha das adolescentes, quando o conservadorismo da família se faz muito evidente. Vale lembrar que de sete em sete anos quebra todas as paredes de sua casa para reerguê-las novamente de forma diferente, deixando-nos todos boquiabertos com as mudanças que realiza constantemente em seu espaço, com tanta facilidade.[...]

De um país em frangalhos, devastado pela guerra, dividido, com a família inacessível para sempre atrás de um muro, vovô teve a oportunidade de participar de um grupo de migração. Era uma facção privilegiada nos conta o Tio Won, um direito concedido a pouquíssimos dos muitos que, na época, sonhavam com uma vida mais tranquila e próspera do outro lado do mundo. Corria boato de um país novo, que recebia muito bem as pessoas, com possibilidade de crescimento. O projeto de imigração incluía a compra de uma fazenda comunitária e uma nova vida como agricultores, condição imposta pelo governo brasileiro para aceitar a vinda destas famílias, que concordaram, claro, apesar de nunca terem sido agricultores na vida.[...] Vovô veio antes da família, com um grupo de 10 pessoas para organizar as coisas. Quando chegaram ao Brasil, descobriram que a terra que haviam comprado em 
Vitória, no Espírito Santo, não passava de um pedaço de chão feito de pântanos e pedras. Era o ano de 1964.

Começa assim a história desta imigração, cheia de esforços, saudades e pequenas alegrias, todas muito valorizadas até hoje. A princesa altiva embarcou em um navio gigante com seus cinco filhos. Tia Young e minha mãe já eram moças. Tia Myung era a mais nova, com apenas 8 anos e compunha o grande time de crianças no navio. Sempre gostei de ouvir a história desta travessia que durou muitos meses, um navio tão cheio de esperança quanto de gente, a maioria deles, como delas, deixando seu país pela primeira vez. Consigo vê-lo, de alguma forma, em meus sonhos, uma cidade em movimento, grandes tanques de lavar roupas enfileirados, um zum zum constante e o mar brilhante, infinito no horizonte. Sei que foi a primeira vez que viram homens negros quando aportaram na África. [...]

Aportaram numa terra estranha, quente, barulhenta. Minha mãe recorda que se impressionava com os feirantes, que gritavam aos quatro ventos; com os mendigos que pediam nas ruas, abandonados à própria sorte; com pessoas de todas as cores e tamanhos que se misturavam na confusão do que chamavam cidade.[...]

E assim foi aos poucos se dando co conhecimento do idealizado Brasil: a cada paladar diferente, entre frutas, vegetais, cultura, língua, costumes, uma nova surpresa, para o bem e para o mal.[...]

Vovô, do alto de sua dignidade, postava-se em alguma parte da região central ao lado de sua engenhoca de churrasquinho grego. Foi seu primeiro negócio. [...]Seu segundo negócio foi uma pastelaria, onde minhas tias trabalharam com afinco. De lá, compraram uma charutaria, e depois da charutaria uma pequena bomboniere. Desta eu finalmente consigo me lembrar. Era próxima à Galeria Olido e tinha um balcão com prateleiras de chocolates, os mais gostosos do mundo, pensava eu.[...]

Moravam em uma pequena casa no Rio Pequeno, construída pelo meu avô com suas próprias mãos.[...]

Por conta de seus casamentos a família aumentou, mas nunca se descolou do conjunto, e este bloco se movimenta através dos tempos, unido em todas as datas festivas e em todos os momentos difíceis.[...]

A devastação, a reconstrução e o crescimento acelerado fizeram da Coreia um país que minha mãe teve dificuldade de reconhecer, quando retornou para mostrá-lo a meu pai, 30 anos depois. Ela também, bem abrasileirada, foi pouco reconhecida entre os seus. "Até que você fala bem o coreano", disse uma senhora na rua, para sua avó, que atônita, só conseguiu responder: "Eu sou coreana."

Minha mãe conheceu meu pai em um curso de pintura que frequentaram juntos às quartas-feiras, dia em que se conhecem os grandes amores.[...]Ele, neto de imigrantes espanhóis e italianos, veio do campo com sua família para a cidade. [...]

Nasci no interior, neste berço de ouro pequeno em Piracicaba,mas com dois meses de idade nos mudamos para uma cidade, que nada mais era que uma trégua no meio de intermináveis canaviais. "Eu moro em Capivari, na divisa com Mombuca." diz a letra desse batuque de negros, que me remete imediatamente a este lugar: uma estrada que eu cruzava de bicicleta. [...]Aos quatro anos mudamos para uma casa que eles construíram tão maravilhosa até hoje, toda de tijolo à vista e de madeira, que foram enchendo de móveis antigos que traziam na sua matéria histórias de tempos imemoriais, maravilhosos, além de objetos detestáveis, como peças orientais de bronze que eu tive de polir muitas e muitas vezes.[...]

Com meus pais conheci o Brasil, e quando digo conhecer, digo imersão, pois nos mudávamos de cidade constantemente, de modo que moramos no Norte, no Nordeste, no Sul, em São Paulo, além de um ano que passei nos Estados Unidos. Sempre retornávamos para o mesmo canavial, com o prazer dos ciscos de cana caindo no quintal. A vida com meus pais foi uma aventura, porque fazíamos de tudo um pouco, e nestas andanças, creio que eles não tinham muita medida do risco com uma criança. Gostavam de coisas boas, mas eram incapazes de desfrutar os lugares como turistas comuns, sempre viajantes curiosos e aventureiros. Por causa de umas peças de cerâmica que ouviram falar, fomos parar em uma ilha do Norte de onde não pudemos sair por muito tempo, pois o barco que levava e trazia e trazia as pessoas afundou diante de nossos olhos. [...] Outra feita, estivemos perdidos nos igarapés dos rios amazônicos, rodando por aqueles caminhos que se faziam sempre iguais por 3 dias. [...] Caminhei com eles por horas e dias por todos os cantos atrás de artesões e artistas populares, admirando os que mexiam com o barro, com madeira, com tinta, com poesia.[...]

Em Belém, foram os banhos de chuvas amazônicas torrenciais que caíam quando voltava da escola, ocasião em que também tinha medo de ser atingida por mangas voadoras, coisa muito comum naqueles lados. Ouvi aterrada muita história do rio, mães d'água, cobras com olhos de fogo que 
tinham a cabeça no pé de igrejas e caudas em redemoinhos no rio quilômetros à frente. No Sul, com mais sorte, já andava por mi mesma, e me lembro de noites entre poetas, músicos e loucos, da inflamante vida cultural, dos teatros, das óperas.[...]

E assim foi, cresci sendo um pouco forasteira durante toda a minha vida, aprendendo a partir e a não olhar para trás, começando de novo em outra parte do país, tendo como pilar central os meus pais, andando por mais caminhos e conhecendo mais coisas do que sou capaz de lembrar. Tive que me desfazer de raízes e procurar outras ininterruptamente e hoje, quando invariavelmente me perguntam de onde eu sou - porque obviamente percebem que não cresci na cidade - tenho vontade de dizer que não sou de lugar nenhum, mas respondo sempre que sou do interior. Também por causa dessas andanças é que sabemos que podemos morar em qualquer canto do mundo, e a nossa casa vive assim hoje, Morena, recebendo pessoas de todos os lugares e de todos os estilos, pois são todos amigos antigos que seguiram rumos diferentes, mas têm um espaço seguro no coração da gente.

No final, reconheço que não deve ter sido muito fácil me educar, porque no final, depois que cresci, mantive o coração de meus pais sempre em suspenso.

Em um dos meus trabalhos na Amazônia tive que saltar de um avião em chamas e dei sorte de cair em uma tribo de índios que julgou que eu era enviada do céu, tendo por isso cuidado de mim. Vê este dedo um pouco torto? Quebrei-o nesta queda. Nas tribos indígenas é que nos sentimos bem em casa, porque eles se comunicam baixo como a nossa família, não possuem pelos pelo corpo, mais escutam do que falam e não importa que língua de qual etnia, esta é sempre um dialeto que nos soa muio familiar.[...]

Certa feita, atravessei o país na boleia do caminhão de Didiu que tinha 24 namoradas espalhadas em locais diferenciados do país, de modo que visitamos todas, e a nossa viagem durou 5 vezes mais do que o tempo necessário. [...]

Ainda queria navegar montada em um cisne na Grécia, subir o Machu Pichu no lombo de uma mula, percorrer, com um bastão na mão, o caminho de São Tiago de Compostela, peregrinar na Índia e estar entre tribos africanas dormindo sob o som de dialetos distantes, mas felizmente, você chegou, e alguma coisa mudou dentro de mim de forma irremediável e para sempre.[...]

Mudamos depois que eu me formei. Uma vila de pescador, eu na escola, Bia no posto de saúde, você brincando na praia, aprendendo a andar se equilibrando contra o vento fresco do Ceará.[...]

É árduo o caminho do encontro. Uma busca que, contada assim, corre o risco de parecer simplista, Morena, porque na verdade os caminhos são tortuosos, mas com insistência e honestidade eles se abrem e é quando quase desistimos que se revelam. Continuamos viajando, agora você comigo, mudando todas as relações de campo: em todos os lugares, você é o meu passaporte de entrada, sou mãe sim, senhores, dessa menina serelepe.[...]

Agora é a minha última linha, venha me ajudar a colocar o ponto final nesta história comprida, que começou antes da gente e continuará depois, com a história que algum dia, você mesma irá contar. 


\subsection{ANEXO F}

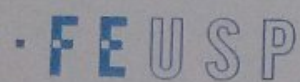

COMISSÃO DE ÉTICA EM PESQUISA

FEUSP 063/2016

Projeto: "Aspectos da Formação da Identidade do Migrante: Pedagogia da Escolha, Imaginário e Sociedade"

Interessados: Antônio Roberto Giraldes e Profa. Dra. Katia Rubio

A Comissão de Ética em Pesquisa da Faculdade de Educação da Universidade de São Paulo analisou os materiais apresentados referentes à pesquisa: "Aspectos da Formação da Identidade do Migrante: Pedagogia da Escolha, Imaginário e Sociedade", de autoria do pesquisador de doutorado: Antônio Roberto Giraldes, orientando da Profa. Dra. Katia Rubio. Considerou que a pesquisa cumpre com todos os requisitos e determinações da Resolução CNS 466/2012 sobre a Ética na Pesquisa com Seres Humanos.

São Paulo, 2 de fevereiro de 2016

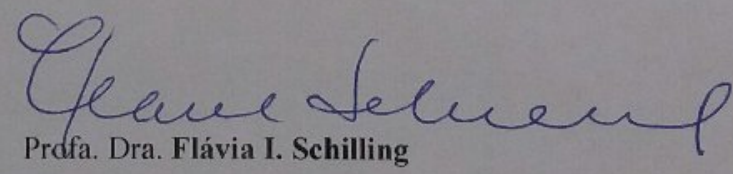

Presidente da Comissão de Ética em Pesquisa da FEUSP

cep.fe@usp.br 